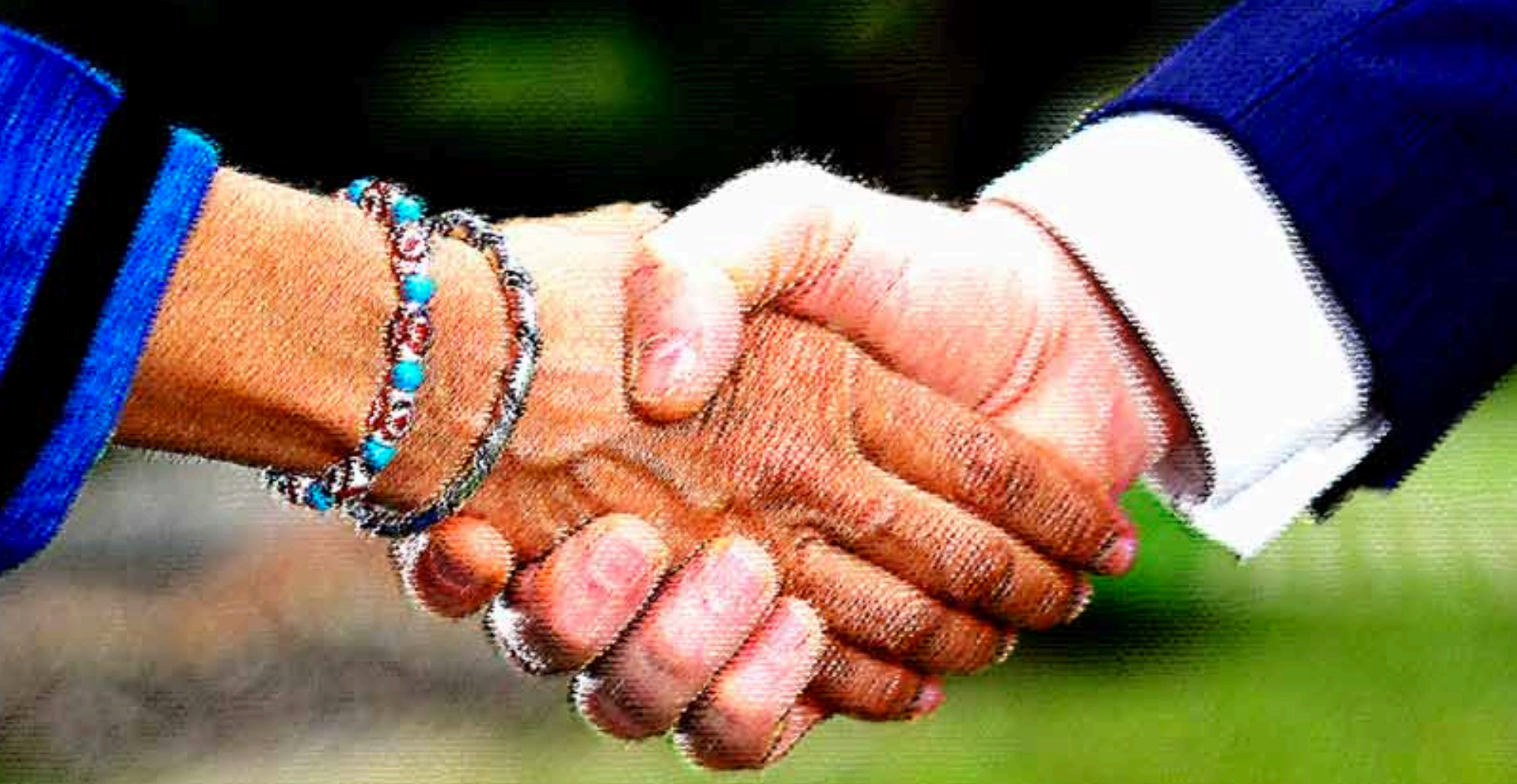

\title{
REINVENTING MUTUAL RECOGNITION ARRANGEMENTS LESSONS FROM INTERNATIONAL EXPERIENCES AND INSIGHTS FOR THE ASEAN REGION
}





\section{REINVENTING MUTUAL RECOGNITION ARRANGEMENTS LESSONS FROM INTERNATIONAL EXPERIENCES AND INSIGHTS FOR THE ASEAN REGION}

Dovelyn Rannveig Mendoza, Demetrios G. Papademetriou, Maria Vincenza Desiderio, Brian Salant, Kate Hooper, and Taylor Elwood 
(C) 2017 Asian Development Bank

6 ADB Avenue, Mandaluyong City, 1550 Metro Manila, Philippines

Tel +632632 4444; Fax +6326362444

www.adb.org; openaccess.adb.org

Some rights reserved. Published in 2017.

Printed in the Philippines.

ISBN 978-92-9257-733-9 (Print), 978-92-9257-734-6 (e-ISBN)

Publication Stock No. RPT178636-2

DOI: http://dx.doi.org/10.22617/RPT178636-2

Cataloging-In-Publication Data

Asian Development Bank.

Reinventing mutual recognition arrangements: Lessons from International Experiences and Insights for the ASEAN Region. Mandaluyong City, Philippines: Asian Development Bank, 2017.

1. Skill mobility. 2. Migrant workers. 3. Association of Southeast Asian Nations. 4. Economic community. 5. Mutual Recognition Arrangement. $\quad$ 6. Migration Policy Institute.

I. Asian Development Bank.

The views expressed in this publication are those of the authors and do not necessarily reflect the views and policies of the Asian Development Bank (ADB) or its Board of Governors or the governments they represent.

ADB does not guarantee the accuracy of the data included in this publication and accepts no responsibility for any consequence of their use. The mention of specific companies or products of manufacturers does not imply that they are endorsed or recommended by ADB in preference to others of a similar nature that are not mentioned.

By making any designation of or reference to a particular territory or geographic area, or by using the term "country" in this document, $\mathrm{ADB}$ does not intend to make any judgments as to the legal or other status of any territory or area.

This work is available under the Creative Commons Attribution 3.0 IGO license (CC BY 3.0 IGO)

https://creativecommons.org/licenses/by/3.0/igo/. By using the content of this publication, you agree to be bound by the terms of this license.

This CC license does not apply to non-ADB copyright materials in this publication. If the material is attributed to another source, please contact the copyright owner or publisher of that source for permission to reproduce it. ADB cannot be held liable for any claims that arise as a result of your use of the material.

Attribution-You should always acknowledge ADB as the source using the following format:

[Author]. [Year of publication]. [Title of the work in italics]. [City of publication]: [Publisher]. @ ADB. [URL or DOI] [license].

Translations-Any translations you create should carry the following disclaimer:

Originally published by ADB in English under the title [title in italics]. (c) ADB. [URL or DOI] [license]. The quality of the translation and its coherence with the original text is the sole responsibility of the translator. The English original of this work is the only official version.

Adaptations-Any adaptations you create should carry the following disclaimer:

This is an adaptation of an original work titled [title in italics]. (c) ADB. [URL or DOI][license]. The views expressed here are those of the authors and do not necessarily reflect the views and policies of ADB or its Board of Governors or the governments they represent. ADB does not endorse this work or guarantee the accuracy of the data included in this publication and accepts no responsibility for any consequence of their use.

Please contact pubsmarketing@adb.org if you have questions or comments with respect to content, or if you wish to obtain copyright permission for your intended use that does not fall within these terms, or for permission to use the ADB logo.

Photos in this publication are property of ADB.

Notes:

In this publication, "\$” refers to US dollars.

ADB recognizes "Laos" as the Lao People's Democratic Republic.

Corrigenda to ADB publications may be found at http://www.adb.org/publications/corrigenda 


\section{Contents}

Tables, Figures, and Boxes

Abbreviations

Acknowledgments

Executive Summary

$\begin{array}{ll}\text { I. Introduction } & 1\end{array}$

II. After 100 Years, Three Insights on Mutual Recognition Arrangements Worldwide 3

III. Three Routes to the Mutual Recognition of Qualifications 6

IV. A Horizontal Approach: Inclusive Mutual Recognition Arrangements Covering Virtually All Occupations

A. European Union Professional Qualifications Directive

B. Trans-Tasman Mutual Recognition Arrangement of New Zealand and Australia

V. A Vertical Approach: Narrow Mutual Recognition Arrangements Limited to Specific Occupations and Sectors

A. Mutual Recognition Arrangement between Architectural Licensing Authorities of the United States and Canada

B. The Washington Accord on Engineering

C. Caribbean Community Skills Certificate Scheme

VI. Umbrella-Agreement Approach: Detailed Guidelines for Future Mutual Recognition Arrangements

A. The France-Québec Accord

B. Asia-Pacific Economic Cooperation Architect Project

VII. Five Key Lessons for the ASEAN Region

Appendixes

Appendix 1: Methodology

Appendix 2: List of Participants in Formal Meetings and Individual Interviews

Appendix 3: Affiliations of Stakeholders Who Completed MRA Implementation Survey 


\section{Tables, Figures, and Boxes}

Table 1: $\quad$ Comparison of the Seven Case Studies, by Dimension and Route

Table 2: Bi- and Trilateral Arrangements Implemented under the Asia-Pacific

Economic Cooperation Architect Project

Figure 1: $\quad$ MRA by Type of Recognition, by Decade, 1900-2010

Figure 2: $\quad$ Country Income Levels and Number of MRAs, 1900-2015

Figure 3: $\quad$ Number of MRA Notifications, Rate of Change, by Decade, 1910-2015

Figure 4: Three Mutual Recognition Arrangements Routes

Figure 5: Development of Four Pathways to Mutual Recognition under the European Union

Professional Qualifications Directive

Figure 6: European Union Automatic Recognition Based on Coordination of Minimum Training Conditions

Figure 7: $\quad$ European Union Automatic Recognition Based on Professional Experience 12

Figure 8: $\quad$ European Union Recognition under the General System 13

Figure 9: $\quad$ European Union Recognition for Temporary Mobility 14

Figure 10: Number of Decisions and Notifications, by Type of Recognition Pathway, 1997-2015 15

Figure 11: Proportion of Decisions and Notifications, by Type of Recognition Pathway, 1997-2015 15

Figure 12: Top 10 Professions: Qualifications Recognized for Permanent Establishment, 1997-2015 16

Figure 13: Recognition under the Trans-Tasman Mutual Recognition Arrangement 20

Figure 14: Mutual Recognition Arrangement between US and Canadian

Architectural Licensing Authorities

Figure 15: Recognition Process of the Washington Accord on Engineering 25

Figure 16: Recognition under the Caribbean Community Mutual Recognition Arrangement 27

Figure 17: Recognition Framework under the France-Québec Mutual Recognition Arrangement 30

Figure 18: Framework for Recognition under the Asia-Pacific Economic Cooperation

Architect Reciprocal Recognition Framework

Box 1: $\quad$ About This Research Project 2

Box 2: $\quad$ The 1975 Sectoral Directives for Medical Doctors $\quad 10$

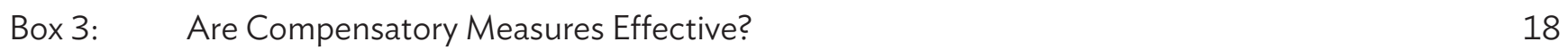

Box 4: $\quad$ The Trans-Tasman Mutual Recognition Arrangement Balancing Act:

Retaining Decentralization while Maintaining Oversight

Box 5: Helping Professionals Undertake Compensatory Measures:

The Case of French Doctors in Québec 


\section{Abbreviations}

$\begin{array}{lll}\text { AACA } & - & \text { Architects Accreditation Council of Australia } \\ \text { ABET } & - & \text { US Accreditation Board for Engineering and Technology } \\ \text { ACMT } & - & \text { Advisory Committee on Medical Training } \\ \text { AEC } & - & \text { ASEAN Economic Community } \\ \text { APEC } & - & \text { Asia-Pacific Economic Cooperation } \\ \text { ASEAN } & - & \text { Association of Southeast Asian Nations } \\ \text { CALA } & - & \text { Canadian Architectural Licensing Authorities } \\ \text { CARICOM } & - & \text { Caribbean Community } \\ \text { CJRF } & - & \text { Cross Jurisdictional Review Forum } \\ \text { CSME } & - & \text { Caribbean Single Market and Economy } \\ \text { CVQ } & - & \text { Caribbean Vocational Qualification } \\ \text { EEA } & - & \text { European Economic Area } \\ \text { EEC } & - & \text { European Economic Community } \\ \text { EU-PQD } & - & \text { European Union's Professional Qualifications Directive } \\ \text { GATS } & - & \text { General Agreement on Trade in Services } \\ \text { GSD } & - & \text { General System Directive } \\ \text { IEA } & - & \text { International Engineering Alliance } \\ \text { MFN } & - & \text { Most favored nation } \\ \text { MPI } & - & \text { Migration Policy Institute } \\ \text { MRA } & - & \text { Mutual recognition arrangement } \\ \text { MRIF } & - & \text { Ministère des Relations internationales et de la Francophonie } \\ \text { NCARB } & - & \text { National Council of Architectural Registration Boards } \\ \text { RSQ } & - & \text { Recrutement Santé Québec } \\ \text { TTMRA } & - & \text { Trans-Tasman Mutual Recognition Arrangement between New Zealand and Australia } \\ \text { UNCTAD } & - & \text { United Nations Conference on Trade and Development } \\ \text { WTO } & - & \text { World Trade Organization }\end{array}$




\section{Acknowledgments}

\footnotetext{
T
}

his report was made possible with the generous support of the Asian Development Bank's Japan Fund for Poverty Reduction. The authors gratefully acknowledge the thoughtful comments of ADB's Guntur Sugiyarto; the editorial contributions of Fayre Makeig, Lauren Shaw, and Michelle Mittelstadt; and the invaluable research assistance of Joel Hernandez, Caitlin Katsiaficas, and Chenyu Liang at the Migration Policy Institute (MPI); and Eric Suan, Katrina Navallo, Anna Malindog-Uy, Jun Baris, Modesta de Castro, Lyndree Malang, and Oth Gagni at ADB. Joe Mark Ganaban assisted in design and typesetting.

They are extremely grateful to Supang Chantanavich, Aris Ananta, Paryono, Sothea Oum, Sengxay Phousinghoa, Siti Rosina Attaullah, Ye Swe Htoon, Fernando Aldaba, Nguyen Thi Thai Lan, and Jeanne Batalova, for providing their expertise and for directly assisting in preparing and administering the surveys and conducting the focus group discussions and meetings that significantly contributed to the findings of this report.

They also give special thanks to Rana Hasan, Ong Keng Yong, Tan Sri Munir Majid, Imelda Nicolas, Yoko Ishikura, Hiroshi Kato, Ichiro Tambo, Akira Murata, Shandre Thangavelu, Teresita Manzala, Jose Cueto, Megawati Santoso, Leandro Conti, Estelita Aguirre, Eddy Krismeidi Soemawilaga, Lesleyanne Hawthorne, and Richard Bedford for providing their significant time and expertise and important referrals.

Finally, they are deeply indebted to Bambang Susantono, ADB vice-president, and Michael Fix, MPI President, for their integral guidance and support in preparing this report. 


\section{Executive Summary}

M utual recognition arrangements (MRAs) are not new. For more than 100 years now, governments and nonstate actors have signed MRAs in an effort to provide a uniform and transparent way of recognizing the qualifications of foreign workers. MRAs are thus important international instruments, yet their scope and use have been rather limited. A Migration Policy Institute (MPI) analysis of data collated by the World Trade Organization (WTO) suggests that most MRAs recognize only diplomas and include very few developing countries as signatories. Moreover, since the 1980s, there has been a noticeable decline in the number of MRAs signed. Indeed, it could be argued that MRAs are essentially 20th-century arrangements, and that their relevance today depends on whether they can adapt to the demands of an ever-changing international labor market.

Governments and regulators around the world have taken three different approaches to mutual recognition, each with its own advantages and disadvantages. Some have signed horizontal MRAs covering virtually all occupations within the signatories' jurisdictions. Many more have opted for vertical MRAs that are occupation or sector specific. And a few have pursued an innovative third option by creating umbrella agreements that identify key terms and conditions to guide future MRA negotiations.

This report discusses each approach and provides an overview of seven case studies from Europe, North America, the Caribbean, and the Asia-Pacific.

\section{Route 1: Horizontal Approach-All-Inclusive MRAs Covering Virtually All Occupations}

European Union Professional Qualifications Directive (EU-PQD). The most comprehensive and longeststanding regionwide MRA in the world resulted from a long and gradual process of mutual recognition that started soon after the creation of the European Economic Community (EEC) in 1957. The centralized approach used by the European Union offers four distinct recognition pathways depending on occupation and intended length of practice.

\section{Trans-Tasman Mutual Recognition Arrangement between New Zealand and Australia (TTMRA).}

A bilateral MRA providing automatic recognition for all occupations but medical doctors. Inherently decentralized, TTMRA delegates administration and monitoring to regulators in each jurisdiction.

\section{Route 2: Vertical Approach-Narrow MRAs Limited to Specific Occupations and Sectors}

Mutual Recognition Arrangement on Architecture between the United States and Canada. A bilateral MRA providing automatic recognition for licensed architects in good standing and with permanent residence or citizenship in the United States or Canada. 
Washington Accord on Engineering. A plurilateral MRA among engineering professional bodies from 15 economies in various regions of the world: Australia; Canada; Taipei,China; Hong Kong, China; Ireland; Japan; the Republic of Korea; Malaysia, New Zealand; Singapore; South Africa; Turkey; the United Kingdom; and the United States. Signatories accept one another's engineering programs as fulfilling educational requirements for practicing as an engineer.

Caribbean Community (CARICOM) Skills Certificate Scheme. A regional MRA offering partial recognition within the Caribbean Community (Antigua and Barbuda, Bahamas, Barbados, Belize, Dominica, Grenada, Guyana, Haiti, Jamaica, Montserrat, Saint Kitts and Nevis, Saint Lucia, Saint Vincent and the Grenadines, Suriname, and Trinidad and Tobago) limited to occupations with university degrees and those in the arts, sports, and media sectors.

\section{Route 3: Umbrella-Agreement Approach-Detailed Guidelines for Future MRAs}

France-Québec Accord. A bilateral arrangement between France and the Canadian province of Québec that sets out a common framework and procedure for the conclusion of occupation-specific MRAs. The accord creates leeway for regulatory bodies in each profession and trade to negotiate the specific eligibility requirements for recognition. More than 70 MRAs have been signed since the accord's entry into force in 2009.

Asia-Pacific Economic Cooperation (APEC) Architect Project Framework. A plurilateral arrangement on architecture involving 14 APEC member economies: Australia; Canada; the People's Republic of China; Hong Kong, China; Japan; the Republic of Korea; Malaysia; Mexico; New Zealand; the Philippines; Singapore; Taipei,China; Thailand; and the United States. Participating signatories enter into bilateral or multilateral MRAs between one another as per the eligibility requirements identified in the framework.

Implementing and enforcing MRAs has proven to be a particularly complex and resource-intensive exercise everywhere. These seven case studies offer many insights for the Association of Southeast Asian Nations (ASEAN) region today, five of which are highlighted below.

First, the harmonization of training standards is hard to achieve and even harder to maintain. In many cases, negotiations to establish harmonized training took decades and deep investments to complete. Moreover, once training standards were harmonized, updating existing systems to reflect the changes required additional negotiations and even more resources. Not surprisingly, some countries have shied away from harmonizing training standards altogether. 
Second, centralized MRA systems require enormous resources to implement, while a decentralized approach, although less resource intensive, is difficult to monitor. Creating and maintaining a centralized bureaucracy dedicated to MRA administration and enforcement makes oversight easier-but the resource requirements can be prohibitive. This is a lesson that even a regional grouping as well-resourced as the European Union has had to learn. Under a decentralized approach, where parties to an MRA utilize local administrative structures, the operational cost may be low but ensuring compliance is difficult. Decentralization is particularly problematic where foreign and native-born workers may not have equal rights (such as within CARICOM) and where buy-in from regulatory authorities is low. Experience shows that registration bodies may unilaterally decide to apply licensing requirements in direct violation, even in defiance, of the MRA.

Third, partial recognition can only be effective if guidelines for compensatory measures are clear and not unnecessarily complex. When compensatory measures are arbitrary and a wide margin of discretion is given to national regulatory authorities, the recognition system remains unpredictable. Compensatory measures have to be commensurate to the gaps that need to be filled and should not impose an excessive burden on professionals and/or delay access to full and independent practice beyond a reasonable period. Adaptation periods are preferable to aptitude tests, and additional training should be used as a last resort. Unnecessarily complicated systems (with complex documentation and other requirements) dissuade professionals from using an MRA.

Fourth, umbrella agreements offer a promising, alternate approach to MRA negotiations-but only if there is political will at the highest levels. The guidelines set forth in umbrella agreements are only as good as the interest and capacity of local actors to engage in negotiating future MRAs. In this regard, it is critical to provide financial and technical support to regulatory bodies and professional associations when negotiating the actual MRAs.

To conclude, MRAs are living documents that require constant revision, improvement, and even periodic renegotiation. Signing an MRA is just the critical first step. Without constant monitoring, evaluation, and revision, an MRA will not stand the test of time and could become easily irrelevant and costly to maintain. 


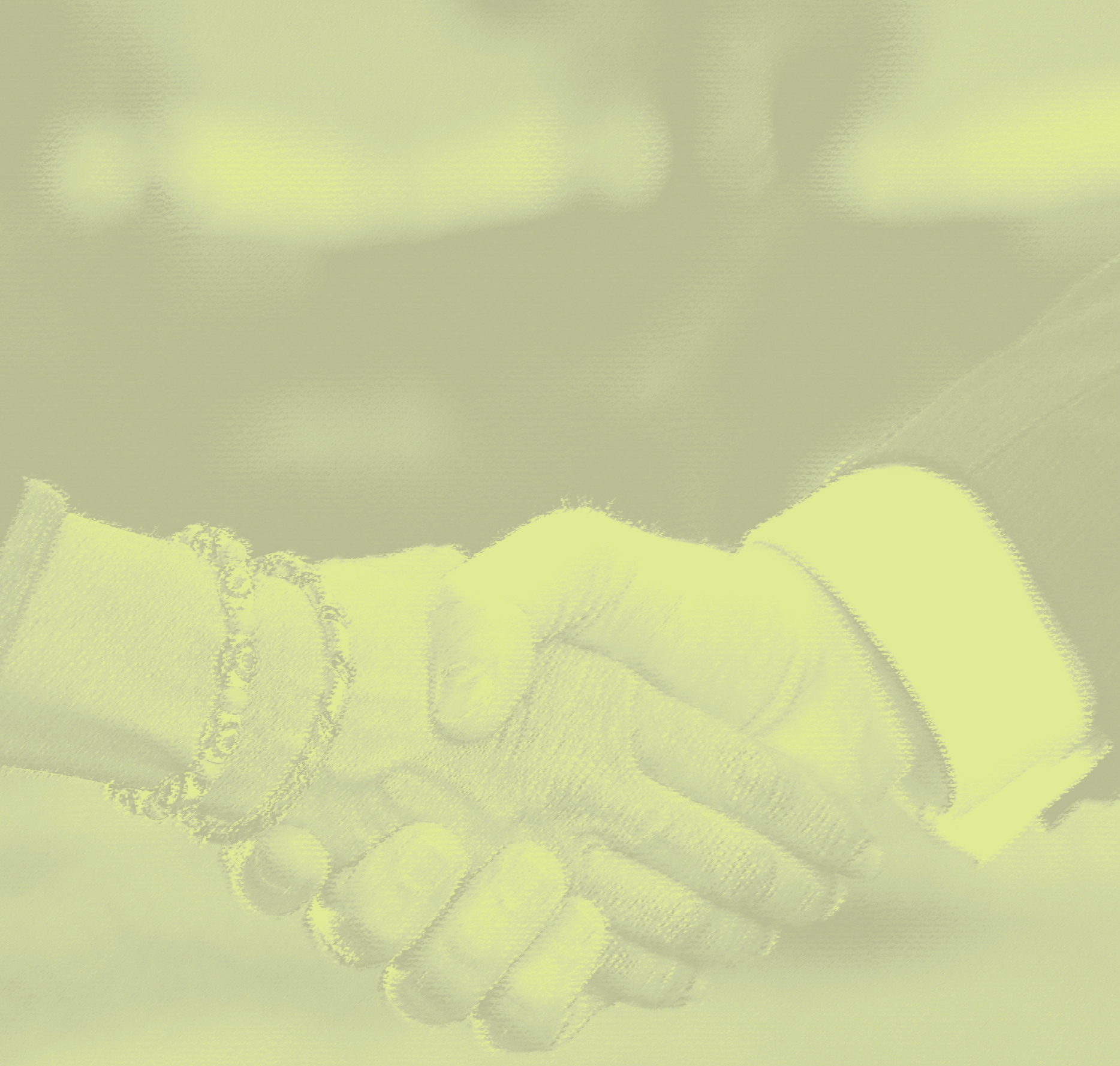




\section{Introduction}

M otivated by an overarching goal to deepen regional integration, in 2005-2014 Member States of the Association of Southeast Asian Nations (ASEAN) concluded regional arrangements for the mutual recognition of professional qualifications in the tourism sector and in six regulated occupations: accounting, architecture, dentistry, engineering, medicine, and nursing. On paper, the mutual recognition arrangements (MRAs) aim to harmonize and strengthen the provision of professional services in the ASEAN region, and ultimately facilitate the intraregional mobility of skilled workers. In practice, however, MRAs have proved difficult to implement effectively, and ASEAN Member States face enormous obstacles to their fulfillment. Much more remains to be done in creating and revising domestic policies, regulations, and processes that are consistent with the spirit of the MRAs.

The main challenges center on capacity issues such as inadequate funding, lack of coordination among government agencies, missing offices and bodies, frequent turnover of personnel, and poor data collection and sharing. In this regard, the ASEAN experience in MRA implementation is far from unique. All over the world, it has proven to be a complex and resource-intensive exercise to implement and enforce the provisions of MRAs.
This report aims to support ASEAN policymakers and regulatory bodies by examining MRAs signed in other regions to see how well they have functioned on the ground. It focuses on the following issues:

- Different routes to mutual recognition. How do MRAs vary and what are the main approaches governments have used in their design?

\section{Progress and challenges in MRA}

implementation. What economic, political, technical, and institutional factors affect the full implementation of MRAs? Why have so many MRAs around the world encountered implementation problems?

- Lessons for the ASEAN region. What are the lessons afforded by international experience in MRA implementation? Are these lessons relevant and applicable to the ASEAN region and, if so, in what ways?

The overall efficacy of the many MRAs negotiated through the years remains unclear. This is primarily because evaluations are generally incomplete, unavailable for public consumption, or do not exist. In order to better understand international experience with MRAs, this report will focus on seven MRAs that have been evaluated or studied at some depth. It is important to note that the highlighted MRAs do not necessarily constitute 
"best practices;" rather, they are promising cases whose approaches and techniques offer critical lessons and that could be potentially refined and adapted to fit the ASEAN context.

Divided into six parts, the report begins by highlighting three key insights on the number and characteristics of MRAs signed so far, using data collated by the World Trade Organization (WTO). Section III introduces the three general routes that governments have taken to facilitate mutual recognition. Sections IV-VI discuss each route in more detail, using seven case studies. The report ends by identifying relevant lessons for the ASEAN region.

\section{Box 1: About This Research Project}

This report is one in a series of four produced through a research partnership between the Asian Development Bank (ADB) and the Migration Policy Institute (MPI). The project aims to improve understanding of the barriers to the free movement of professionals within the Association of Southeast Asian Nations (ASEAN) region and to support the development of strategies to overcome these hurdles.

The reports in this series draw on the insights of 387 regional and international experts and practitioners through their participation in focus group discussions, meetings, and surveys. Contributors include ASEAN Member State officials directly responsible for Mutual Recognition Arrangement (MRA) implementation, as well as private-sector employers, academics, training directors, MRA monitoring committee members, and current and former ASEAN Secretariat officials.

ADB and MPI convened 12 days of focus group discussions and meetings between May and September 2015 that were attended by more than 100 regional stakeholders. See the Appendixes of this report for more on the methodology of the study and for a complete list of stakeholders involved. 


\section{After 100 Years, Three Insights on Mutual Recognition Arrangements Worldwide}

M utual recognition arrangements (MRAs) are not new. For more than 100 years, governments and nonstate actors worldwide have signed MRAs to more effectively recognize the qualifications of foreigners within their borders. One of the earliest MRAs dates back to 1892, when representatives from the colonies of New South Wales, Victoria, Queensland, South Australia, Western Australia, and New Zealand unanimously agreed to mutually recognize certificates of competency for surveyors. ${ }^{1}$

There is no record in the academic and policy literature assessing how many MRAs have been negotiated to date. The closest approximation of the number and characteristics of MRAs worldwide can be gleaned from collating the information governments have submitted to WTO. MRAs have been incorporated in the international trade regime mainly through the WTO General Agreement on Trade in Services (GATS) that entered into force in January 1995. GATS Article VII allows its members to set up bilateral or plurilateral MRAs and deviate from the WTO most favored nation (MFN) obligations, a principle that limits discrimination by ensuring that all Member States enjoy similar terms of trade. As Zarrilli explains, the MFN exemption for MRAs reflects the "widespread assumption among governments that MRAs hold great potential for facilitating the movement of professional services suppliers, are instrumental to policy reform, and represent powerful tools for economic integration."

As of July 2016, 60 notifications had been communicated under GATS Article VII, involving 24 WTO members and covering 205 bilateral agreements, with the oldest going as far back as 1900. Although far from representing all MRAs concluded worldwide, these notifications point to useful insights on their nature. Three of these are quite instructive for ASEAN policymakers, especially given the region's social and economic diversity.

\section{First, the majority of MRAs recognize academic qualifications only and not on-the-job \\ qualifications. On-the-job qualifications include} informal education, work experience, and expertise. As Figure 1 shows, nearly three-fourths of MRAs signed in any given year between 1900 and 2013 involve the recognition of diplomas. In total, just 52 agreements, or $26 \%$ of all MRAs, grant recognition of on-the-job qualifications. For instance, in 2012, the Russian Federation signed an agreement with the Former Yugoslav Republic of Macedonia granting mutual recognition of diplomas.

1 Australian Government Productivity Commission, Mutual Recognition Schemes: Productivity Commission Research Report (Canberra: Australian Government Productivity Commission, 2015), www.pc.gov.au/inquiries/completed/mutual-recognition-schemes/ report/mutual-recognition-schemes.pdf.

2 Simonetta Zarrilli, "Moving Professionals beyond National Borders: Mutual Recognition Agreements and the GATS United Nations Conference on Trade and Development" (working paper UNCTAD/ DITC/TNCD/2005/2, United Nations Conference on Trade and Development, Geneva, February 2005), http://unctad.org/en/Docs/ditctncd20052_en.pdf. 
Figure 1: MRA by Type of Recognition, by Decade, 1900-2010

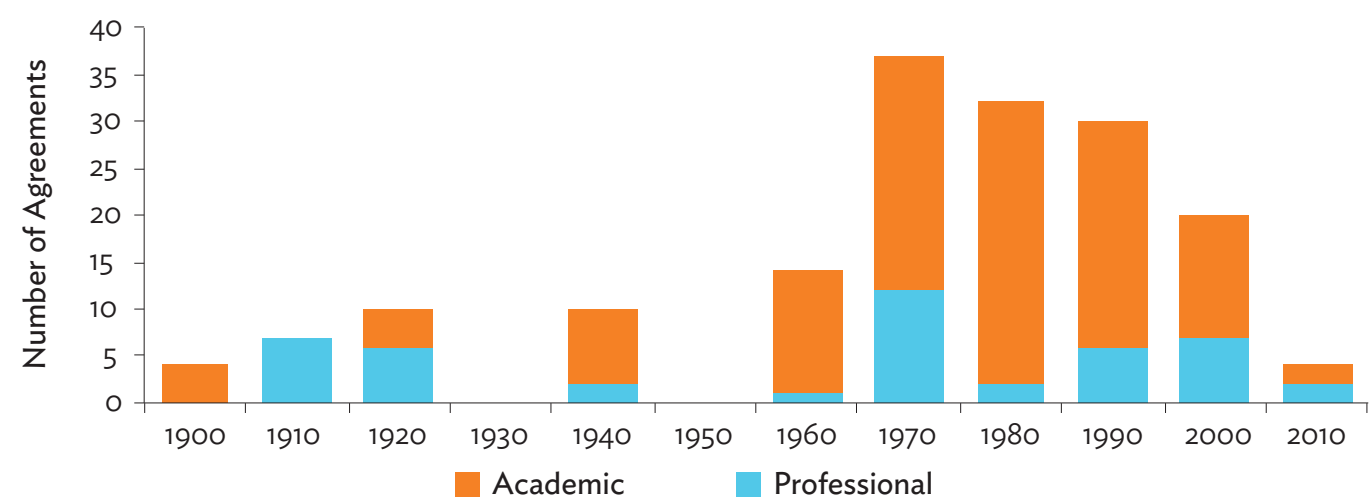

MRA = mutual recognition arrangement.

Source: Migration Policy Institute (MPI) calculation based on Word Trade Organization (WTO) data of notifications under GATS Article VII. See WTO, "Council for Trade in Services, Technical and Administrative Information, Notifications, Article 7.4," accessed 1 September 2016.

https://docs.wto.org/dol2fe/Pages/FE_Browse/FE_B_009.aspx?TopLevel=8660\#/.

Second, developing countries are still very much under-represented in MRAs. Developed countries have led and dominated MRA initiatives and the setting of standards for professional and academic qualifications from the outset. Figure 2 maps all the MRAs reported under GATS Article VII, differentiated by countries' income level when the MRAs were signed, and the total number of agreements per country. A huge majority, nearly $80 \%$, of MRAs involve high- or middle-income countries, with Colombia and Brazil reporting the largest number. Haiti was the only low-income

Figure 2: Country Income Levels and Number of MRAs, 1900-2015

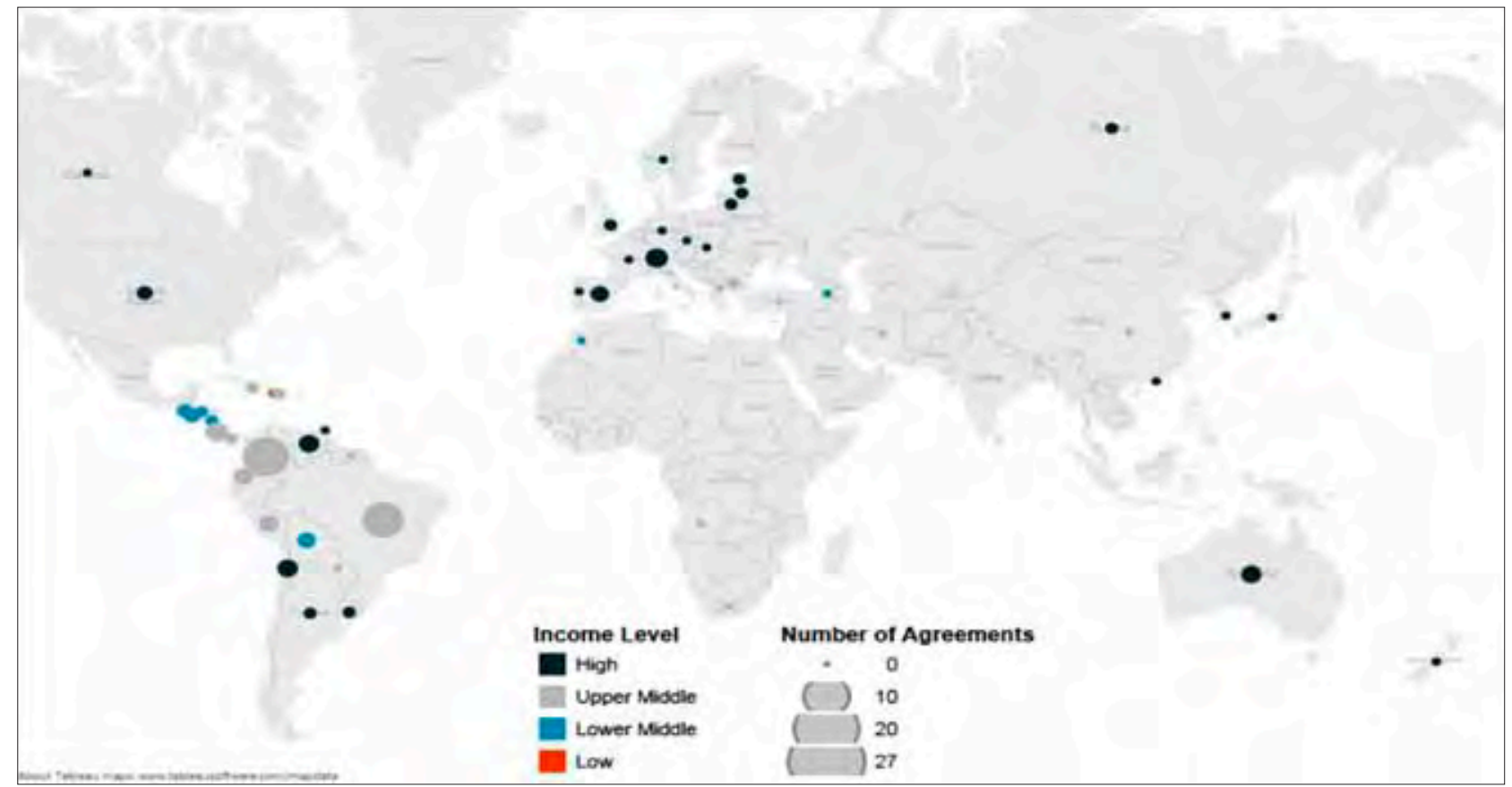

MRAs = mutual recognition arrangements.

Source: MPI calculation based on WTO data of notifications under GATS Article VII. See WTO, "Council for Trade in Services, Technical and Administrative Information, Notifications, Article 7.4," accessed 1 September 2016. 
country to participate in a reported MRA. For Zarrilli, because "market forces will not by themselves provide a solution to the problem ... some sort of mechanism should, then, be put in place to facilitate developing country participation in MRAs."

Third, the number of MRAs reached its peak during the 1970s and has declined since then. Of the 205 MRAs signed between 1900 and 2013, more than one-third were signed between 1970 and 1980 . Since 1980, there has been a noticeable decline in MRAs, as shown in Figure 3. Between 2000 and
2010, 20 notifications were submitted, just over half the number reported in the 1970s. The Russian Federation filed two notifications in 2015.

Pinpointing the exact reasons for the decline in notifications over the past 40 years is difficult. There is an argument to be made that MRAs are first and foremost 20th-century instruments, and that their continued relevance and use in the 21 st century will likely depend on how they adapt to meet the demands of an ever-changing labor market landscape.

Figure 3: Number of MRA Notifications, Rate of Change, by Decade, 1910-2015*

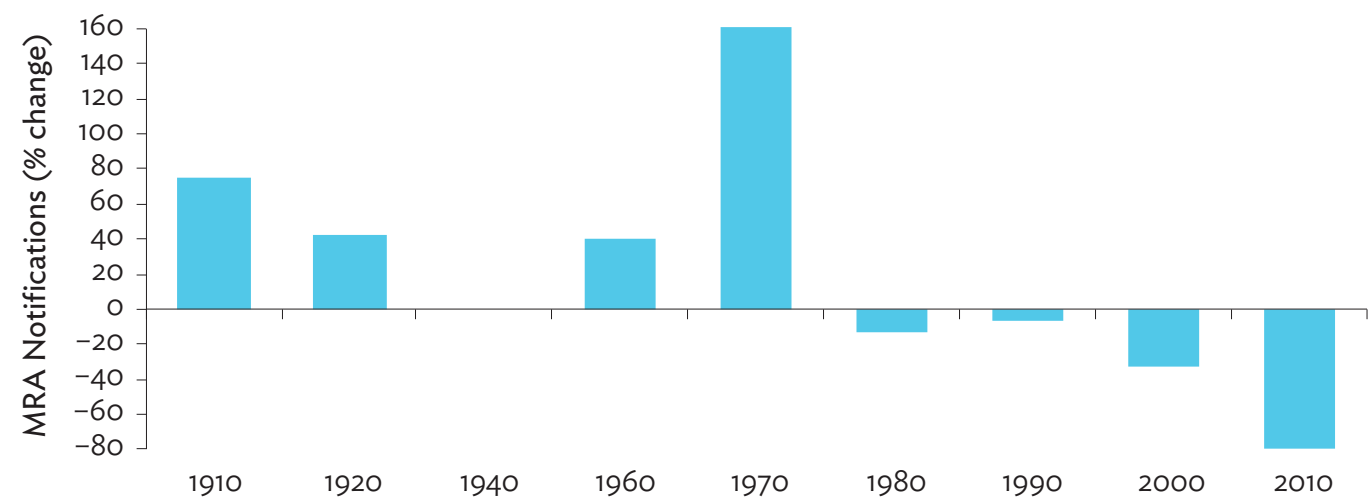

* The 2010 bar includes data through 2015.

Source: MPI calculation based on notifications to WTO under GATS Article VII. See WTO, "Council for Trade in Services, Technical and Administrative Information, Notifications, Article 7.4," Accessed 1 September 2016. 


\section{Three Routes to the Mutual Recognition of Qualifications}

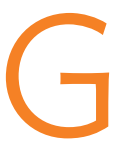

overnments and regulators around the world have taken different approaches to mutual recognition. A few have taken a horizontal approach, by signing sweeping and comprehensive MRAs that cover virtually all occupations within the signatories' jurisdiction. More have taken a much narrower vertical approach and signed occupation- or sector-specific MRAs. A third route involves umbrella agreements that detail key terms and conditions of the mutual recognition process while leaving room for further negotiations by professional bodies or governments.

Figure 4 highlights these three routes and identifies the seven MRAs that will be the focus of this report. These MRAs were chosen primarily because they have been studied or evaluated to some extent, making it possible to draw lessons from them. They also represent the diversity of existing MRAs worldwide, which is important for ASEAN policymakers as they explore their options.

Figure 4: Three Mutual Recognition Arrangements Routes

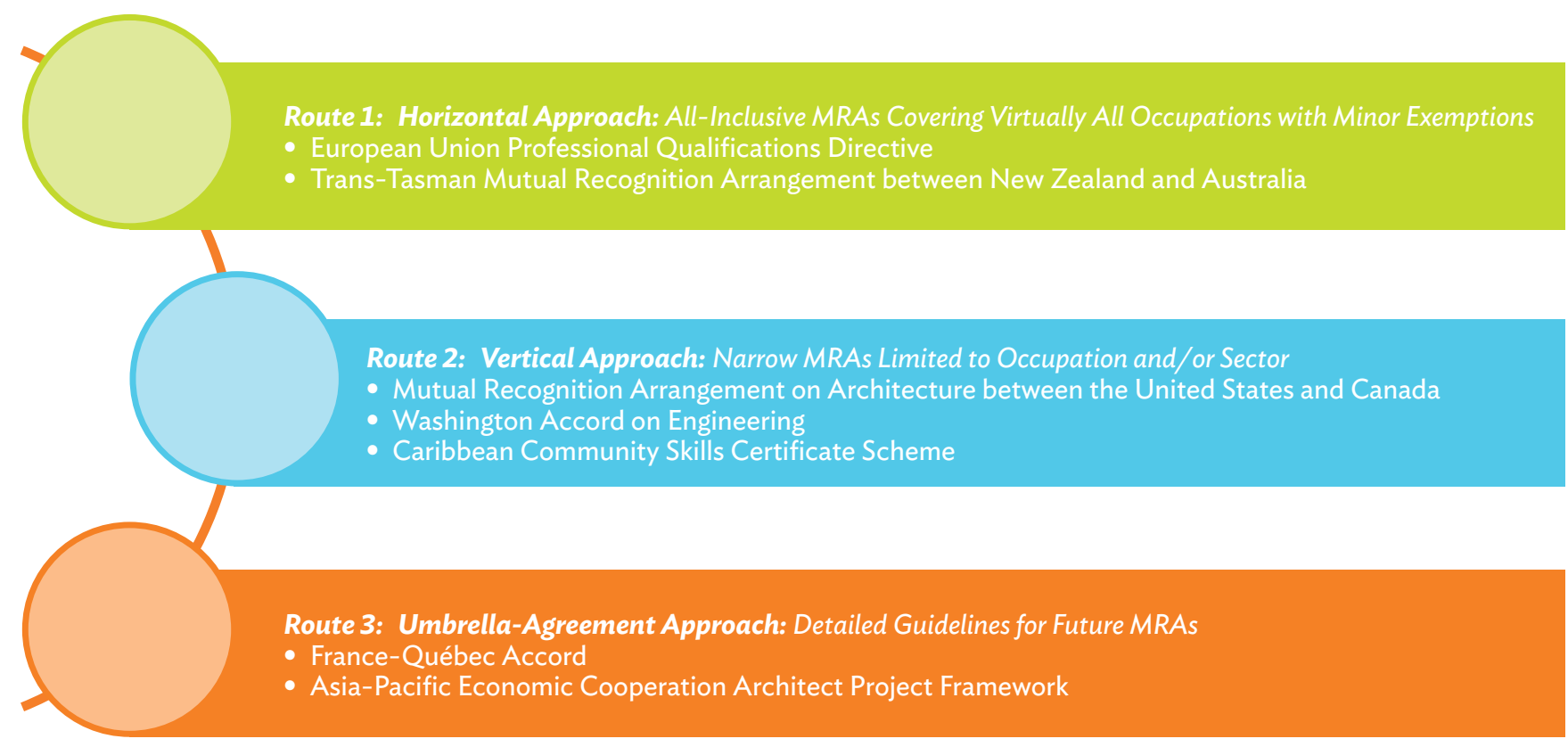

MRAs = mutual recognition arrangements.

Source: Authors' rendering. 
MRAs vary along many dimensions, including:

Scope. Some MRAs cover an entire sector or sectors and involve multiple occupations, while others are limited to one type of occupation. The most comprehensive MRAs cover virtually all occupations with a few noted exceptions.

\section{Number of parties and their legal} designation. MRAs are signed bilaterally or multilaterally and can be initiated by governments - most often as part of trade agreements or other broader economic liberalization agreements-or by professional bodies themselves.

\section{Automaticity of the recognition process.} Some MRAs recognize qualifications automatically, while others offer only partial recognition. Where recognition is automatic, a country-of-origin notification that the professional has met the MRA requirements is typically enough. Or there may be a simple verification process, in which the applicant is asked to produce certification or a license issued by the origin country. In a partial recognition framework, foreign professionals undergo a recognition process at their destination. This is based on eligibility requirements negotiated in the MRA, which also typically specifies when compensation measures can be required of professionals who fail to meet the eligibility criteria.

\section{Degree of institutionalization. MRAs create} implementing institutions at national and/ or regional levels that vary in organizational footprint and mandate. Some MRAs even institutionalize human resource development issues by ensuring the quality of supplied professionals through the harmonization of training, or by linking recognition rights to guarantees of some level of labor market access. Indeed, a few MRAs are linked to free trade agreements, which alongside recognition also provide full or limited access to the domestic labor market.

Level of post-MRA guarantees. Many MRAs include safeguards that enable authorities at destination to keep or reassert regulatory jurisdiction to further important national policy objectives, including protecting the public interest. Such safeguards may include the possibility of rescinding recognition obligations if another party changes regulations in ways that violate either the letter or spirit of the MRA.

MRAs are dynamic, multidimensional, multilayered international instruments. No two MRAs are alike, even those that follow the same approach. For instance, although the EU Professional Qualifications Directive (EU-PQD) and the Trans-Tasman Mutual Recognition Arrangement between New Zealand and Australia (TTMRA) are both horizontal MRAs, only the latter offers automatic recognition for all occupations (EU-PQD offers automatic or partial recognition). With a focus on decentralization, TTMRA also has a lighter institutional footprint than the EU-PQD. Similar observations can be made on other case studies to be highlighted in this report.

Table 1 shows the seven MRAs along the key dimensions given above to highlight the diverse approaches governments have taken to facilitating mutual recognition. 
Table 1: Comparison of the Seven Case Studies, by Dimension and Route

\begin{tabular}{|c|c|c|c|c|c|c|c|c|c|}
\hline \multirow{3}{*}{\multicolumn{3}{|c|}{ Selected Dimensions }} & \multicolumn{7}{|c|}{ Routes to Mutual Recognition } \\
\hline & & & \multicolumn{2}{|c|}{$\begin{array}{l}\text { Route 1: } \\
\text { Horizontal Approach }\end{array}$} & \multicolumn{3}{|c|}{$\begin{array}{c}\text { Route 2: } \\
\text { Vertical Approach }\end{array}$} & \multicolumn{2}{|c|}{$\begin{array}{c}\text { Route 3: } \\
\text { Umbrella Agreement } \\
\text { Approach }\end{array}$} \\
\hline & & & $\begin{array}{c}\text { EU } \\
\text { Professional } \\
\text { Qualifications } \\
\text { Directive }\end{array}$ & $\begin{array}{l}\text { Trans- } \\
\text { Tasman } \\
\text { MRA }\end{array}$ & $\begin{array}{l}\text { US-Canada } \\
\text { MRA on } \\
\text { Architecture }\end{array}$ & $\begin{array}{l}\text { Washington } \\
\text { Accord on } \\
\text { Engineering }\end{array}$ & $\begin{array}{l}\text { CARICOM } \\
\text { Skills } \\
\text { Certificate } \\
\text { Scheme }\end{array}$ & $\begin{array}{l}\text { France- } \\
\text { Québec } \\
\text { Accord }\end{array}$ & $\begin{array}{c}\text { APEC } \\
\text { Architect } \\
\text { Project } \\
\text { Framework }\end{array}$ \\
\hline \multirow{2}{*}{\multicolumn{2}{|c|}{ Automaticity of recognition }} & Automatic & & & & & & \multirow{2}{*}{\multicolumn{2}{|c|}{$\begin{array}{l}\text { Not applicable } \\
\text { Not applicable }\end{array}$}} \\
\hline & & Partial & & & & & & & \\
\hline \multirow{4}{*}{ Signatories } & \multirow{2}{*}{$\begin{array}{l}\text { Number of } \\
\text { signatories }\end{array}$} & Bilateral & & & & & & & \\
\hline & & Multilateral & & & & & & & \\
\hline & \multirow{2}{*}{$\begin{array}{l}\text { Type of } \\
\text { signatories }\end{array}$} & $\begin{array}{l}\text { Nonstate } \\
\text { actors }\end{array}$ & & & & & & & \\
\hline & & State actors & & & & & & & \\
\hline \multirow{2}{*}{\multicolumn{2}{|c|}{ Post-MRA guarantees }} & Minimal & & & & & & & \\
\hline & & Strong & & & & & & & \\
\hline \multirow{6}{*}{$\begin{array}{l}\text { Level of } \\
\text { institutionalization }\end{array}$} & \multirow{2}{*}{$\begin{array}{l}\text { Level of } \\
\text { centralization }\end{array}$} & Decentralized & & & & & & & \\
\hline & & Centralized & & & & & & & \\
\hline & \multirow{2}{*}{$\begin{array}{l}\text { Harmonization } \\
\text { of training }\end{array}$} & Full & & & & & & & \\
\hline & & None & & & & & & & \\
\hline & \multirow{2}{*}{$\begin{array}{l}\text { Labor market } \\
\text { access }\end{array}$} & None & & & & & & & \\
\hline & & Full & & & & & & & \\
\hline
\end{tabular}

APEC $=$ Asia-Pacific Economic Cooperation, $C A R I C O M=$ Caribbean Community, EU $=$ European Union, MRAs = mutual recognition arrangements. Source: Authors' rendering based on information from APEC, APEC Architect Operations Manual (Vancouver: APEC, 2014),

www.apecarchitects.org/images/pdf/repairs/operations-manual-2014.pdf; Australian Government Productivity Commission, Mutual Recognition Schemes: Productivity Commission Research Report (Canberra: Australian Government Productivity Commission, 2015),

www.pc.gov.au/inquiries/completed/mutual-recognition-schemes/report/mutual-recognition-schemes.pdf; Caribbean Community (CARICOM), "CARICOM Single Market and Economy (CSME): Overview," accessed 25 August 2016, http://caricom.org/work-areas/overview/caricom-singlemarke-and-economy; European Commission, Evaluation of the Professional Qualifications Directive (Directive 2005/36/EC) (Brussels: European Commission, 5 July 2016), 10, http://ec.europa.eu/internal_market/qualifications/docs/news/20110706-evaluation-directive-200536ec_ en. pdf; International Engineering Alliance (IEA), 25 Years - Washington Accords (1989-2014): Celebrating International Engineering Education Standards and Recognition (Wellington, New Zealand: IEA, 2014), www.ieagreements.org/25_years/25YearsWashingtonAccord-A5booklet-FINAL. pdf; Mutual Recognition Agreement between the National Council of Architectural Registration Boards and the Canadian Architectural Licensing Authorities (CALA), San Diego, California, 17 June 2013, www.ncarb.org/Publications/ /media/Files/PDF/Special-Paper/2013ncarb-cala_mra. pdf; Relations internationales et Francophonie Québec, “Detailed Information about the Agreement," accessed 21 June 2016, www.mrif.gouv.qc.ca/en/ententes-et-engagements/ententes-internationales/reconnaissance-qualifications/entente-en-details. 


\section{A Horizontal Approach: Inclusive Mutual Recognition Arrangements Covering Virtually All Occupations}

\section{T} he EU-PQD and the TTMRA between New Zealand and Australia are two of the most comprehensive MRAs in the world. Both are rooted in deep socioeconomic integration dating back many decades. The European Union, officially created in 1993, was the result of gradual integration and expansion that started in 1956 when six core states-Belgium, France, Italy, Luxembourg, the Netherlands, and West Germany-founded the union's predecessor, the European Economic Community (EEC), with the European Coal and Steel Community. The next step in European integration was the 1957 Treaty of Rome. Currently, the European Union has 28 Member States.

Likewise, TTMRA involves the closely linked economies of Australia and New Zealand, which share a common language, close historical ties, a free trade area whose antecedents date back to the 1920s, and more than 80 bilateral agreements on issues such as trade, taxation, social security, and the movement of people. ${ }^{4}$

Given the ASEAN goal of establishing a single market and production base through the creation of the ASEAN Economic Community (AEC), ${ }^{5}$ the experience of MRA implementation in the European Union, a roughly similar geopolitical

4 Australian Government, Department of Foreign Affairs and Trade, "Australia-New Zealand Closer Economic Relations Trade Agreement," updated February 2016, http://dfat.gov.au/trade/ agreements/anzcerta/pages/australia-new-zealand-closereconomic-relations-trade-agreement.aspx.

5 Demetrios G. Papademetriou, Dovelyn Rannveig Mendoza, Brian Salant, and Guntur Sugiyarto, Achieving Skill Mobility in the ASEAN Economic Community: Challenges, Opportunities, and Policy Implications (Manila: Asian Development Bank, 2016), www.migrationpolicy. org/research/achieving-skill-mobility-asean-economic-communitychallenges-opportunities-and-policy. entity, offers potentially important lessons. The case of New Zealand and Australia is instructive for the terms of the agreement made.

\section{A. European Union Professional Qualifications Directive}

\section{Background}

The EU-PQD is the product of a long and gradual process of mutual recognition that began with a series of transitional directives in the 1960s on the automatic recognition of professional experience in the crafts, commerce, and industry sectors. Within less than two decades, the system widened and allowed for the automatic recognition of qualifications in several regulated professions in health care, and much later, architecture. Figure 5 maps the development of the mutual recognition scheme within the European Union over the past 50 years.

The first two sectoral directives, issued in 1975, set out the mutual recognition of qualifications and harmonized training standards for medical doctors (see Box 2). ${ }^{6}$ An advisory committee composed of medical professionals from the then nine Member States outlined the basic requirements for doctors, including the content and minimum length of

6 Council of the European Communities, "Council Directive of 16 June 1975 concerning the mutual recognition of diplomas, certificates and other evidence of formal qualifications in medicine, including measures to facilitate the effective exercise of the right of establishment and freedom to provide services (75/362/EEC)," Official Journal L 167, 30 June 1975, http: / / eur-lex.europa.eu/ legal-content/EN/TXT/PDF/?uri=CELEX:31975L0362\&from=EN; Council of the European Communities, "Council Directive 75/363/ EEC of 16 June 1975 concerning the coordination of provisions laid down by law, regulation or administrative action in respect of activities of doctors," Official Journal L 167, 30 June 1975, 14-16, http: / /eurlex.europa.eu/legal-content/EN/TXT/?uri=CELEX:31975L0363. 
Figure 5: Development of Four Pathways to Mutual Recognition under the European Union Professional Qualifications Directive

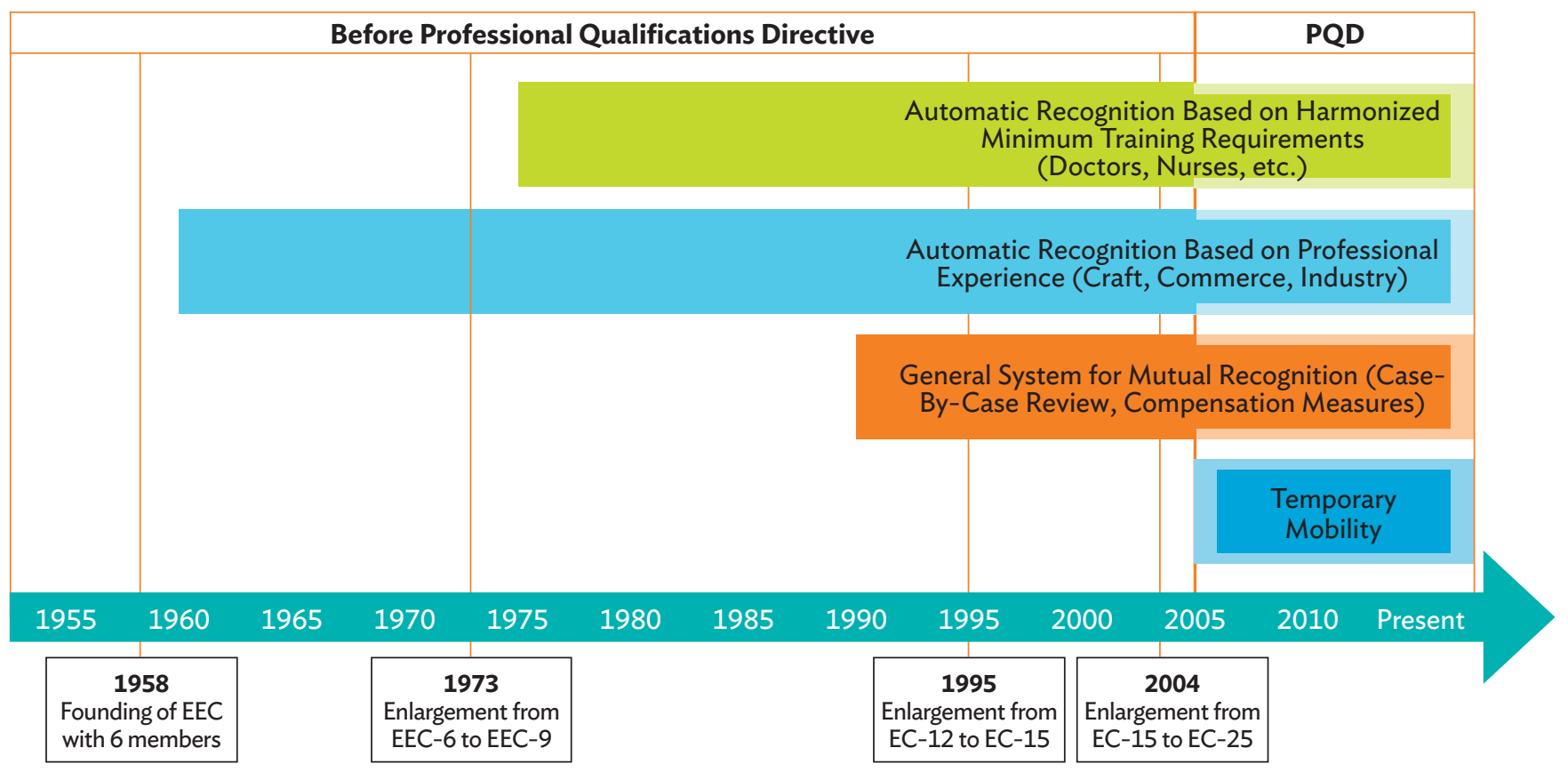

EU-PQD = European Union Professional Qualifications Directive.

* European Community enlargements also took place in 1981 (Greece), 1986 (Portugal, Spain), 2007 (Bulgaria, Romania), and 2013 (Croatia).

${ }^{* *}$ The European Union was official known as the European Economic Community (EEC) at its founding in 1958, renamed as the European Community (EC) in 1993, and consolidated as the European Union (EU) in 2009 by the Treaty of Lisbon.

Sources: Authors' rendering based on information obtained from European Commission, Evaluation of the Professional Qualifications Directive (Directive 2005/36/EC) (Brussels: European Commission, 2011), 9-11, http://ec.europa.eu/internal_market/qualifications/docs/news/20110706evaluation-directive-200536ec_en.pdf; European Commission, "From 6 to 28 Members," accessed 23 June 2016, http://ec.europa.eu/ enlargement/policy/from-6-to-28-members/index_en.htm; Simonetta Zarrilli, "Moving Professionals beyond National Borders: Mutual Recognition Agreements and the GATS United Nations Conference on Trade and Development" (working paper UNCTAD/DITC/TNCD/2005/2, United Nations Conference on Trade and Development, Geneva, February 2005), http://unctad.org/en/Docs/ditctncd20052_en. pdf; Julia Nielson, "Chapter 10-Trade Agreements and Recognition," in Quality and Recognition in Higher Education-The Cross-Border Challenge (Paris: OECD Publishing, 2004), 187-89, www.oecd.org/edu/skills-beyond-school/33729996.pdf.

\section{Box 2: The 1975 Sectoral Directives for Medical Doctors}

Directive 75/362/EEC required each EU Member State to recognize the formal qualifications of doctors trained in other Member States, giving these qualifications "the same effect in its territory as those which the Member State itself awards," and requiring foreign nationals to abide by the same rules of conduct as citizens of that country when providing services. This applied both to basic medical training and specialist postgraduate training courses, where undertaken in two or more Member States. Doctors whose qualifications did not meet these new standards but could provide a certificate attesting they had lawfully practiced medicine for at least 3 of the past 5 years were also eligible for mutual recognition.

Directive 75/363/EEC set out the minimum training standards for doctors, including the minimum training period for undergraduates (a 6-year course or 5,550 hours of instruction) and method of instruction (theoretical and practical training at or under the supervision of a university, including supervised clinical experience in a hospital). It also set out the minimum length of specialist postgraduate courses ( 3 to 5 years, depending on the subject) and stated that specialist qualifications could only be awarded to candidates who had completed their basic medical training.

Sources: European Union, “Council Directive 75/362/EEC of 16 June 1975 concerning the mutual recognition of diplomas, certificates and other evidence of formal qualifications in medicine, including measures to facilitate the effective exercise of the right of establishment and freedom to provide services," Official Journal L 167, 30 June 1975, 1-13, http://eur-lex.europa.eu/legal-content/EN/

TXT/?uri=CELEX\%3A31975L0362; Council of the European Communities, "Council Directive 75/363/EEC of 16 June 1975 concerning the coordination of provisions laid down by law, regulation or administrative action in respect of activities of doctors," Official Journal $\mathrm{L}$ 167, 30 June 1975, 14-16, http://eur-lex.europa.eu/legal-content/EN/TXT/? Uri=CELEX:31975L0363. 
training programs. ${ }^{7}$ The Advisory Committee on Medical Training (ACMT) was established in 1976 to compare training methods and courses in medical training, and to update these two directives where necessary. ${ }^{8}$ Over the next decade, sectoral directives were also issued for general care nursing (1977), veterinary surgeons (1978), dental practitioners (1978), midwives (1980), pharmacists (1985), architects (1985), and doctors with specialist training (1986). ${ }^{9}$

While initially effective in harmonizing training standards, the sectoral approach has been criticized for being very resource intensive and slow to respond to developments in the field or in practice. ${ }^{10}$ For example, initial negotiations to establish the sectoral directive in architecture took 17 years to complete, and updating these directives to reflect changes in education or training in the sector required additional negotiations. ${ }^{11}$ Other criticisms of the sectoral directives included the slow recognition process, its exclusion of new professions or developments in the field, and its failure to check the skills of professionals (for example, to see whether they had maintained or updated their skills since qualifying). ${ }^{12}$

Thus, in the mid-1980s, the region moved away from automatic recognition under the sectoral directives and instead focused on a general system covering all regulated professions not covered by the existing directives. ${ }^{13}$ Unlike the sectoral approach, the General System Directive (GSD)

7 Thomas Keighley, European Union Standards for Nursing and Midwifery: Information for Accession Countries, 2nd edition (Copenhagen: World Health Organization, 2009), 1-3; Arthur H. Crisp, "Medical Training in the European Community," Postgraduate Medical Journal 66, no. 778 (1990): 628.

8 Crisp, "Medical Training in the European Community."

9 Sallie Nicholas, "The Challenges of Free Movement of Health Professionals," in Health Policy and European Union Enlargement, eds. Martin McKee, Laura MacLehose, and Ellen Nolte (New York and Maidenhead, UK: Open University Press, 2004), 83.

10 Keighley, European Union Standards for Nursing and Midwifery, 2-3.

11 Frances Plimmer, "Mutual Recognition of Professional Qualifications: The European Union System" (background paper for the 3rd FIG Regional Conference, Jakarta, 3-7 October 2004), 11.

12 Micheline van Riemsdijk, "Obstacles to the Free Movement of Professionals: Mutual Recognition of Professional Qualifications in the European Union," European Journal of Migration and Law 15, no. 1 (2013): 47-68.

13 This was established by mutual recognition directives in 1989, 1992, and 1999. does not provide for automatic recognition of qualifications. Instead, professionals fully qualified to practice a regulated profession in the country of origin must apply to the relevant national regulatory body in the destination country to have their qualifications assessed. ${ }^{14}$ If this body finds substantial differences between national requirements and migrant training (e.g., in duration or content), it will then require compensatory measures (an aptitude test or adaptation period, for example)..$^{15}$

\section{The Recognition Process}

The EU-PQD attempted to both simplify and widen options for professionals by merging the different pathways developed over the course of half a century and by adding an additional pathway for EU citizens who were interested in practicing on a temporary basis. EU professionals applying for recognition today have four options depending on their occupation and desired length of stay in the country of destination. As Figures 6 to 9 illustrate, the process varies for each pathway, with some offering a more direct route to recognition than others.

Pathway 1: Automatic recognition for professionals with harmonized minimum training standards strengthens the system exacted for architects, dentists, doctors, midwives, nurses, pharmacists, and veterinary surgeons. Using this pathway, a professional must obtain the formal qualifications stipulated in the PQD and send an application to the destination country. Notably, the content and duration of the training are not to be verified by the relevant

14 If they have obtained their education or training outside the European Union, they must first have their qualifications recognized and be permitted to practice in an EU Member State, European Economic Area (EEA) country, or Switzerland, in order to be eligible for recognition in another state under this "general system." See European Commission, Guide for Users of the General System for the Recognition of Professional Qualifications, MARKT/D/8327/2001-EN (Brussels: European Commission, 2001), http://ec.europa.eu/internal_ market/qualifications/docs/guide/guide_en.pdf.

15 European Commission, Commission Staff Working Document on the Transposition and Implementation of the Professional Qualifications Directive (Brussels: European Commission, 2010), 4-5, http:// ec.europa.eu/internal_market/qualifications/docs/evaluation/staffworking-doc_en.pdf. 
destination-country authorities. Qualifications listed in Annex $V$ of the PQD, which identifies the degrees and certificates that meet the minimum training requirements, are to be given automatic recognition in all EU Member States ${ }^{16}$ (see Figure 6).

Pathway 2: Automatic recognition based on professional experience and/or training in a craft, commercial, or industrial profession follows the system established in the 1960s. ${ }^{17}$ Using this pathway, a professional must first obtain experience and/or training in a specified profession for a minimum number of years, which varies by occupation (e.g., 6 years for a self-employed civil engineer). ${ }^{18}$ The country of destination will automatically recognize the previous pursuit of activity as sufficient proof of qualification (see Figure 7).

\section{Figure 6: European Union Automatic Recognition Based on Coordination of Minimum Training Conditions}

\section{Country of Origin}

\section{Country of Destination}

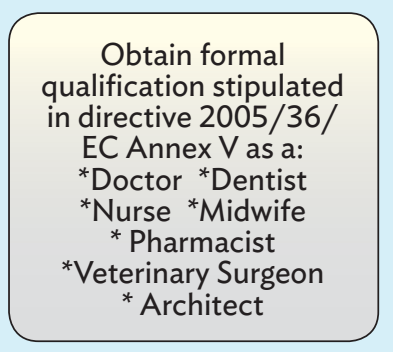

Send application to the host Member State.

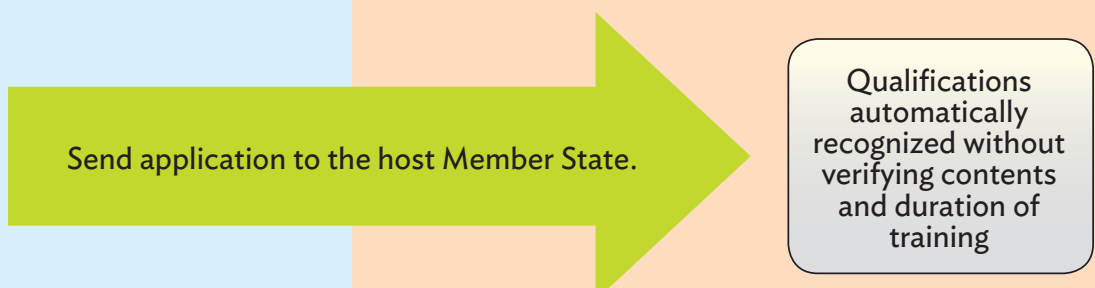

Sources: Authors' rendering based on information obtained from Articles 21-49 of the European Union, "Directive 2005/36/EC of the European Parliament and of the Council of 7 September 2005 on the recognition of professional qualifications," Official Journal L 255/22, 30 September 2005, http://eur-lex.europa.eu/legal-content/EN/TXT/?uri=celex\%3A32005L0036; European Commission, Evaluation of the Professional Qualifications Directive (Directive 2005/36/EC), 9-11.

\section{Figure 7: European Union Automatic Recognition Based on Professional Experience}

\section{Country of Origin}

\section{Country of Destination}

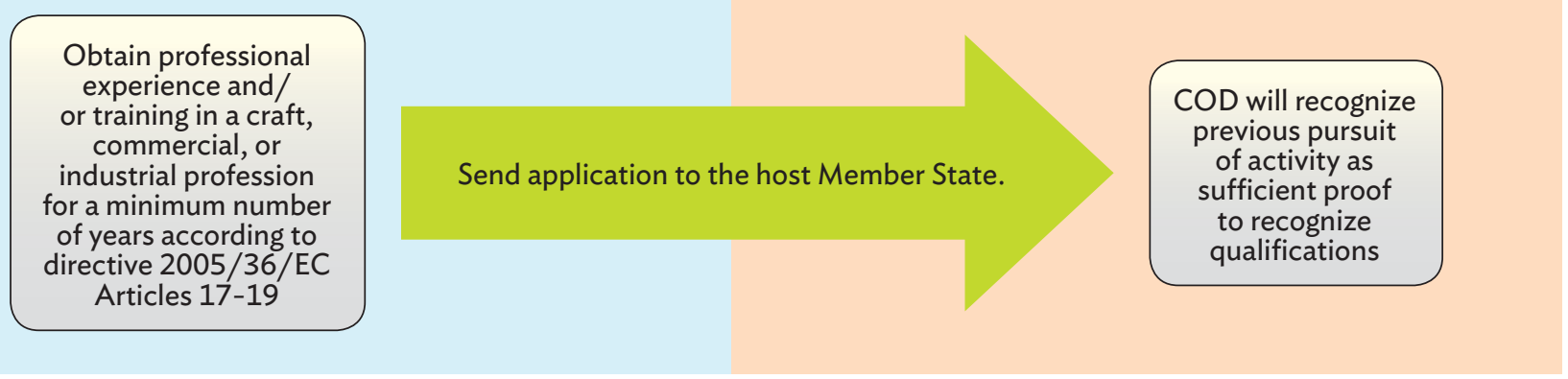

Sources: Authors' rendering based on information obtained from Articles 16-20 of the European Union, "Directive 2005/36/EC of the European Parliament and of the Council of 7 September 2005 on the recognition of professional qualifications," Official Journal L 255/22; European Commission, Evaluation of the Professional Qualifications Directive (Directive 2005/36/EC), 9-11.

16 European Commission, Evaluation of the Professional Qualifications Directive (Directive 2005/36/EC) (Brussels: European Commission, 5 July 2016), 10, http://ec.europa.eu/internal_market/qualifications/ docs/news/20110706-evaluation-directive-200536ec_en.pdf.
17 Ibid.

18 See Article 17 of the European Union, "Directive 2005/36/EC of the European Parliament and of the Council of 7 September 2005 on the recognition of professional qualifications," Official Journal L 255, 30 September 2005, http:/ / eur-lex.europa.eu/legal-content/EN/ TXT/?uri=CELEX:02005L0036-20110324. 
Pathway 3: The general system allows professionals who do not qualify for the first two pathways to apply for recognition on a case-by-case basis. Destination countries assess the training of wouldbe migrants, both in terms of duration and content, to determine whether gaps exist between this training and the professional qualifications needed to practice at destination. If considerable gaps exist, host-country authorities can ask applicants to undertake an aptitude test or an adaptation period ${ }^{19}$ (see Figure 8).

Pathway 4: A new pathway for temporary mobility, introduced by the EU-PQD, drastically reduces the administrative requirements for professionals intending to practice provisionally. Would-be migrants need no longer submit a request for their qualifications to be recognized; rather, on an annual basis they inform the destination country of their intention to provide services. Authorities at destination may check their qualifications only if they work in professions that impact public health or safety ${ }^{20}$ (see Figure 9).

Essentially, the scheme assumes that professionals who already lawfully practice in one Member State should be able to legitimately practice for a temporary period of time in any other Member State. The registration process does not involve a fee, or hold up the provision of services. ${ }^{21}$ Notably, professionals need not register with a professional group.

\section{Figure 8: European Union Recognition under the General System}

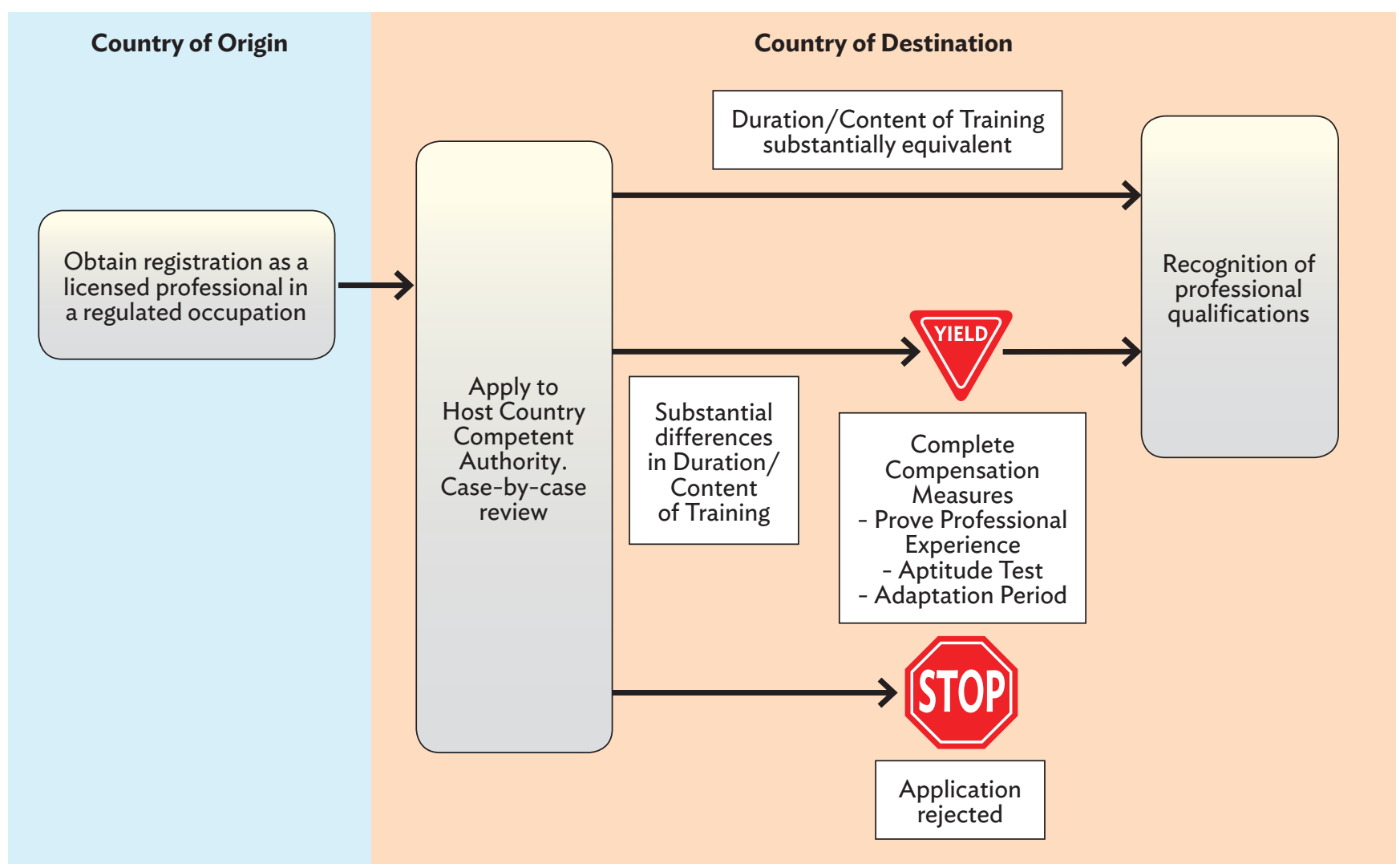

Sources: Authors' rendering based on information from European Commission, Evaluation of the Professional Qualifications Directive (Directive 2005/36/EC), 9-11; European Commission, Guide for Users of the General System for the Recognition of Professional Qualifications, Markt/ D/8327/2001-EN (Brussels: European Commission,2001), http://ec.europa.eu/internal_market/qualifications/docs/guide/guide_en.pdf; Articles 10-15 of the European Union, "Directive 2005/36/EC of the European Parliament and of the Council of 7 September 2005 on the recognition of professional qualifications," Official Journal L 255/22.

19 European Commission, Evaluation of the Professional Qualifications Directive, 10.
20 Ibid., 11.

21 Ibid., 63. 
Figure 9: European Union Recognition for Temporary Mobility

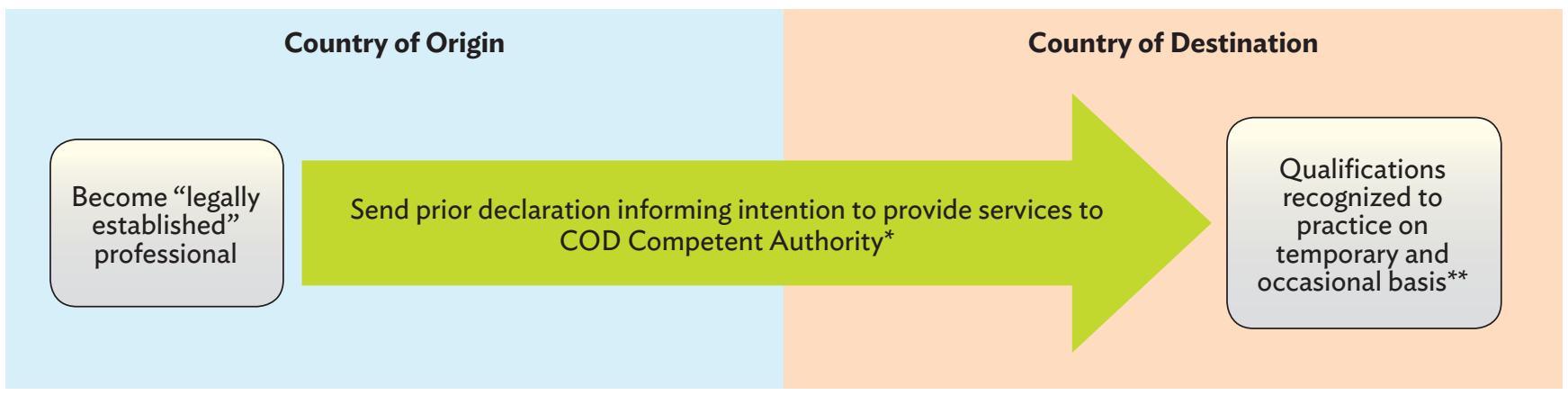

* Country of Destination may require prior declaration once per year if temporary practice continues past 12 months.

** Professionals in regulated professions having public health and safety implications may have their qualifications exceptionally checked by competent COD authorities.

Sources: Authors' rendering based on information drawn from Articles 5-7 of the European Union, "Directive 2005/36/EC of the European Parliament and of the Council of 7 September 2005 on the recognition of professional qualifications," Official Journal L 255/22; European

Commission, Evaluation of the Professional Qualifications Directive (Directive 2005/36/EC), 9-11.

\section{Progress and Challenges in Implementation}

Although the PQD consolidated the 15 existing directives on mutual recognition, implementation remained a challenge. In fact, no EU Member State met the initial 2-year deadline for transposing the PQD into legislation and regulations. The Commission began infringement proceedings against several Member States and even took some to court. ${ }^{22}$

\section{a. Progress in Implementation}

After the PQD was introduced in 2005, the number of annual decisions increased by $200 \%$, from just under 20,000 between 2003 and 2004 to nearly 60,000 by 2013 . In total, nearly half a million decisions $(482,805)$ on mutual recognition were made between 2005 and 2015, 84\% of which granted full recognition of qualifications (see Figure 10).
An increasing proportion of professionals also began using the automatic recognition route for sectoral professions: between 2007 and 2015, 174,656 professionals used this route, accounting for $48 \%$ of all decisions made in the same timeframe. Meanwhile, the proportion of decisions made under the general system (the third pathway outlined above) fell to 146,580 professionals ( $41 \%$ of total decisions). ${ }^{23}$

A small proportion of professionals have utilized the PQD for arts and crafts (averaging around 4,400 decisions per year since 2007), while an even smaller proportion have taken advantage of the temporary mobility regime (between 2007 and 2015, there were only 23,105 notifications of intention to practice a profession temporarily, i.e., about $6 \%$ of the total number of decisions made).
22 European Commission, Commission Staff Working Document on Transposition and Implementation of the Professional Qualifications Directive, 6-7.
23 These data are for general system primary applicants, and these calculations exclude positive automatic sectoral professions and automatic recognition of professional experience (crafts). "Approval" covers (1) positive automatic general system (no compensation measures imposed), (2) positive after aptitude test (general system), and (3) positive after adaptation period (general system). See European Commission, "Statistics," accessed 9 May 2016, http:// ec.europa.eu/growth/tools-databases/regprof/index.cfm. 
Figure 10: Number of Decisions and Notifications, by Type of Recognition Pathway, 1997-2015

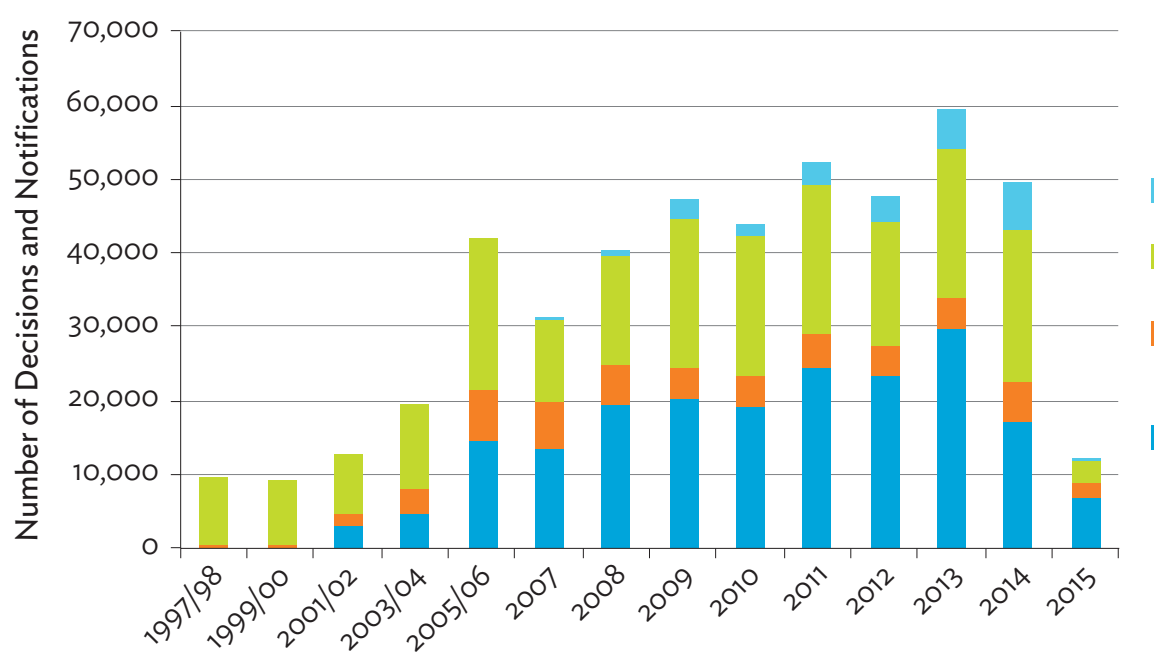

Temporary

Automatic General System

Automatic Recognition of Professional Experience ('Crafts')

Automatic Sectoral Professions

Note: These figures represent the number of both positive and negative decisions made regarding the recognition of professional qualifications for the purpose of permanent and temporary establishment within the European Union, European Economic Area (EEA), and Switzerland (under automatic sectoral professions).

Source: European Commission, “Statistics," accessed 9 May 2016, http://ec.europa.eu/growth/tools-databases/regprof/index.cfm.

Figure 11: Proportion of Decisions and Notifications, by Type of Recognition Pathway, 1997-2015

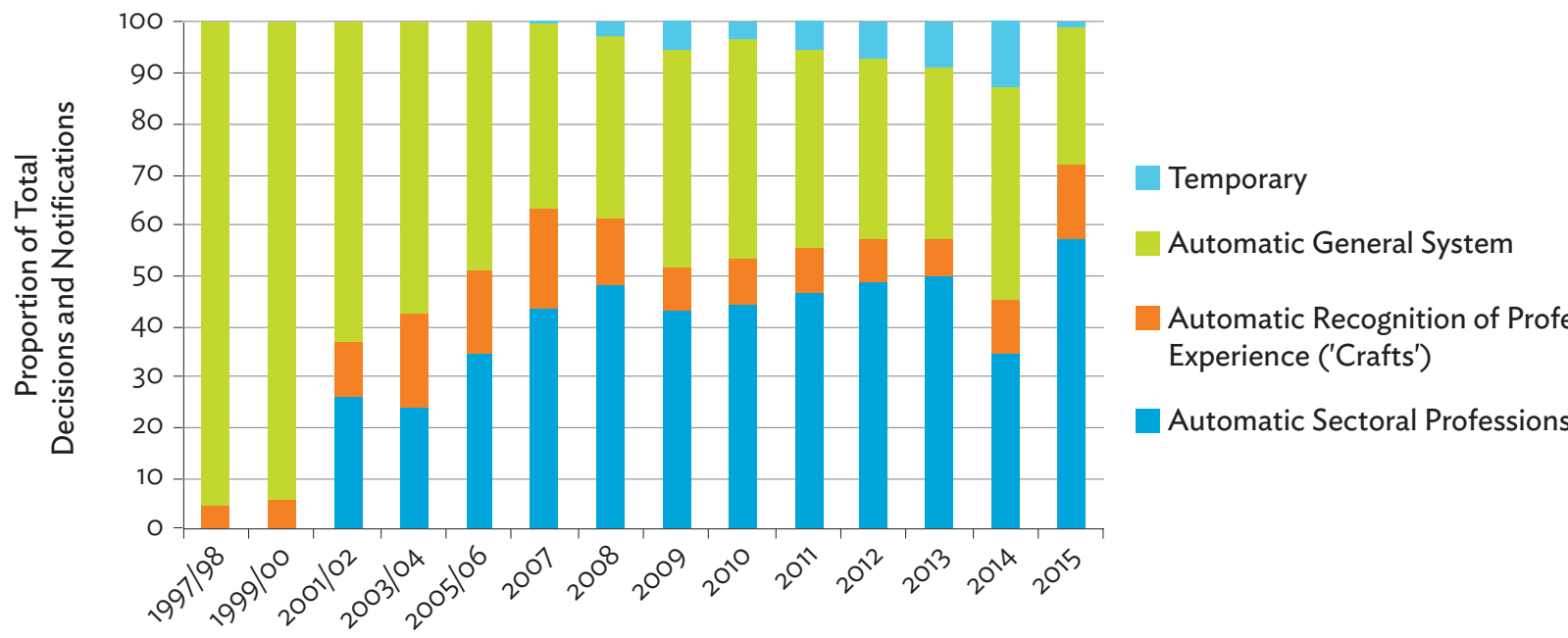

Note: These figures represent the number of both positive and negative decisions made regarding the recognition of professional qualifications for the purpose of permanent and temporary establishment within the European Union, European Economic Area (EEA), and Switzerland (under automatic sectoral professions).

Source: European Commission, "Statistics," accessed 9 May 2016. 
Among the regulated professions, health professionals have the highest levels of mobility in the European Union. ${ }^{24}$ Between 2007 and 2015, 232,497 health professionals received recognition, with doctors and nurses constituting the highest proportion at $30 \%$ and $22 \%$ respectively. The professionals who made most use of the general system were school teachers $(51,267)$, physiotherapists $(23,437)$, and electricians $(7,973)^{25}$ (see Figure 12).

\section{b. Challenges to Full Implementation}

Despite the increase in the number of professionals using the PQD system, participation remains small compared to the overall number of professionals in the European Union. The 53,000 annual applications made through the PQD since 2005 represent just $0.14 \%$ of all employed professionals in the European Union (estimated at 40 million), a miniscule amount by most measures. ${ }^{26}$

In 2011, the European Commission, the executive body responsible for proposing and implementing EU legislation, published the most recent official evaluation of the PQD. The exhaustive and rigorous review noted various implementation challenges that limit the expansion of opportunities for recognition under the PQD. ${ }^{27}$ The problems center on seven key areas.

\section{Keeping an up-to-date list of degrees, certifications, and minimum training conditions has been difficult. Since training curricula change} and new degrees are created, the list of qualifications covered under the automatic recognition pathway requires regular updates - a task that has been plagued by delays. In architecture, for instance,

Figure 12: Top 10 Professions: Qualifications Recognized for Permanent Establishment, 1997-2015

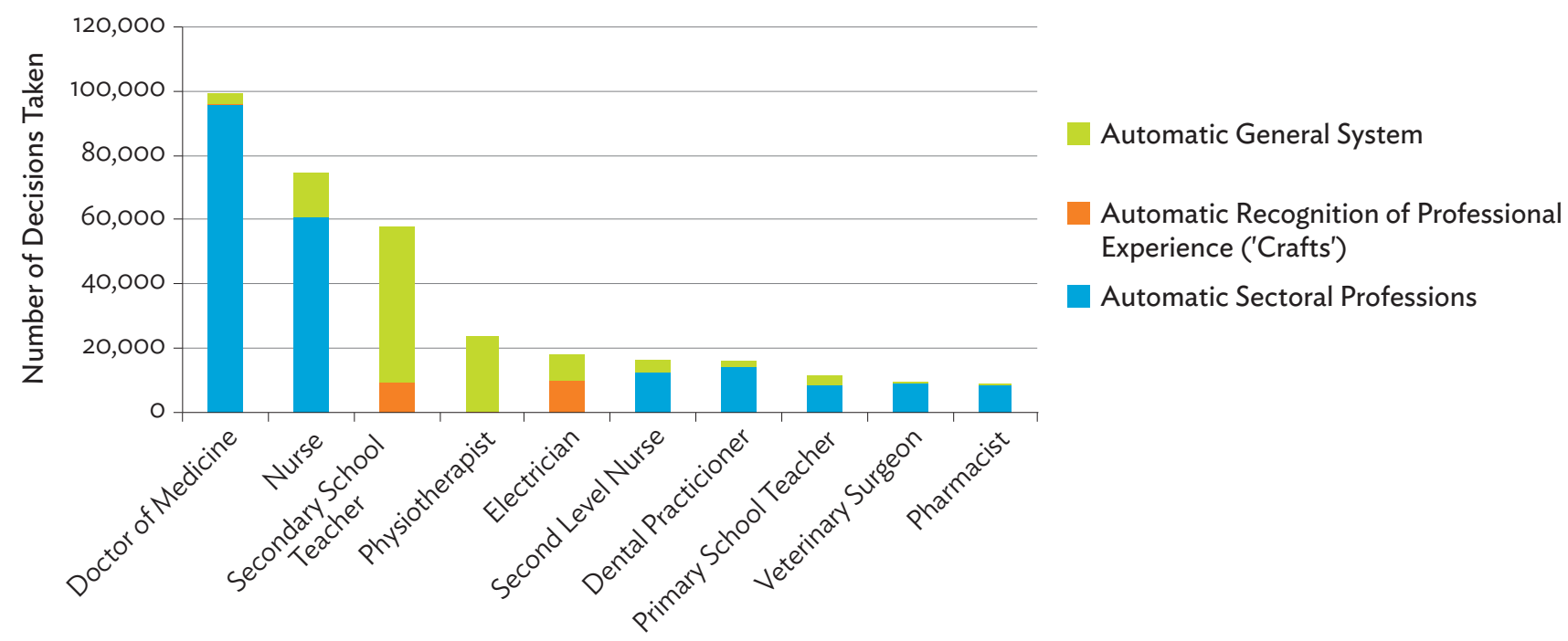

Note: These figures represent the number of both positive and negative decisions made regarding the recognition of professional qualifications for the purpose of permanent establishment within the European Union, European Economic Area (EEA), and Switzerland (under automatic sectoral professions). Source: European Commission, "Statistics," accessed 9 May 2016.

24 European Commission, Evaluation of the Professional Qualifications Directive, 42.

25 European Commission, "Statistics."
26 Jeanne Batalova, Andriy Shymonyak, and Guntur Sugiyarto, Firing Up Regional Brain Networks: The Promise of Brain Circulation in the ASEAN Economic Community (Manila: ADB, 2016), 33.

27 European Commission, Evaluation of the Professional Qualifications Directive. 
it takes an average of 14 months between the notification of a new diploma and its publicationa significant delay that leaves students uncertain whether their qualifications will be recognized by another Member State in a timely fashion. The review also found that existing rules on harmonized minimum conditions for a number of fields were not regularly updated to reflect scientific and technical advancements. ${ }^{28}$ In 2010, some rules remaining on the books dated as far back as the 1980s.

\section{The automatic pathways are not being used as} intended due to the complexity of the eligibility criteria. Some professionals, for instance, prefer submitting an application through the general system even though they qualify for the automatic route. Evaluators also found the eligibility criteria complex and difficult to use. For instance, when assessing an application for automatic recognition, hostcountry authorities must verify that the proposed professional activity appears on at least one of three lists in Directive Annex IV-each of which comes with different conditions for recognition that must also be checked. ${ }^{29}$

\section{Extensive documentation requirements make the system cumbersome and time-consuming.}

The case-by-case assessment of applications can be complex; authorities reported experiencing difficulties obtaining transcripts to verify the training completed by applicants, as well as confusion over what types of documents could serve as proof of applicants' professional experience. ${ }^{30}$

\section{Deadlines to review and adjudicate applications are not being met. The PQD sets processing-}

time deadlines for the authorities that review requests for recognition: 1 month to indicate missing documents and 3 months to make a decision. ${ }^{31}$ Often, authorities failed to acknowledge that they had received applications or to inform applicants of missing documents. Meanwhile, some applicants asked to provide additional documents had to contact national administrations or training institutions, causing significant delays (in some cases more than a year) in the processing of their applications. ${ }^{32}$

\section{Some authorities still impose requirements} beyond what is necessary. Some destinationcountry authorities still require professionals seeking temporary work to provide additional information or accept certain conditions (e.g., relating to time, duration, and/or type of the intended activities, and intended location). Others require that a declaration of intent to practice be made far in advance. This is directly counter to the PQD provision that professionals should only have to submit a declaration immediately before they begin to provide the service. ${ }^{33}$

\section{Compensatory measures can be arbitrary and their implementation costly, especially for regulators with smaller offices. Destination-country} authorities enjoy considerable discretion in defining training gaps and, as a result, in choosing whether and which compensatory measures to impose. ${ }^{34}$ The Commission's evaluation of the PQD raised concerns that some countries may have overstepped their discretion. Further, administering the compensatory measures can be complex and costly (as Box 3 explains). $\begin{array}{ll}28 & \text { Ibid., 47. } \\ 29 & \text { Ibid., 59-60. } \\ 30 & \text { Ibid., 21. }\end{array}$ 


\section{Box 3: Are Compensatory Measures Effective?}

The 2011 evaluation of the EU Professional Qualifications Directive (EU-PQD) by the European Commission sought to examine whether regulatory authorities utilized compensatory measures effectively and what impact they had on migrant professionals. Specifically, had compensatory measures discouraged professionals from moving within the region, and were professionals able to acquire the necessary "missing" competences?

If they are to be efficient, compensatory measures must be both flexible and tailored to the gap identified between the applicant's training and host-country professional requirements. The evaluation highlighted complaints from EU Member States that the development of compensatory measures was complex and costly. Some regulatory authorities described experiencing difficulties creating aptitude tests, in part because of the resulting need to set up examination boards. Similarly, authorities' ability to offer adaptation periods was contingent on the willingness of employers to participate.

Applying compensation measures has proven to be a particular challenge in countries that receive relatively few requests for recognition and where small regulatory authorities lack experience in creating appropriate tests or facilitating adaptation periods.

There was no question among those interviewed for the evaluation that compensatory measures both safeguard public safety and benefit migrants since they facilitate successful integration into their professional fields at destination. But their actual benefits ultimately depend on the capacity and resources of the institutions tasked with implementing them.

Source: European Commission, Evaluation of the Professional Qualifications Directive (Directive 2005/36/EC) (Brussels: European Commission, 2011), http://ec.europa.eu/internal_market/qualifications/docs/news/20110706-evaluationdirective-200536ec_en.pdf.

\section{Professionals still find it difficult to access information despite extensive efforts at} improvement. The PQD set up new information structures to inform and assist EU Member State nationals seeking recognition for their professional qualifications. Yet, the 2011 evaluation notes, there are still many contact points and their roles are not always clear. There is anecdotal evidence of local authorities offering incorrect information or discouraging applicants by stating, for instance, that an aptitude test is very difficult. Some national contact points have insufficient resources and require institutional support if they are to function more effectively. ${ }^{35}$

It is clear from these seven related issues that although the all-inclusive approach of the PQD offers the best opportunity for recognition among EU professionals, realizing its potential is not easy. This is true despite the decades of experience and tremendous resources that the European Union has invested in the process of mutual recognition.

\section{B. Trans-Tasman Mutual Recognition Arrangement of New Zealand and Australia}

\section{Background}

Like the EU-PQD, the TTMRA is broad-based and "horizontal." Yet its approach differs in two crucial ways. First, instead of four pathways, TTMRA has only one: automatic recognition, regardless of occupation. Professionals registered in either Australia or New Zealand can quickly register in the other jurisdiction without compensatory measures.

Second, unlike in the European Union, New Zealand and Australia did not make significant changes to their standards or establish a centralized bureaucracy for administration and enforcement. Rather, TTMRA architects created an inherently decentralized MRA: administration and compliance are largely delegated to regulators in each jurisdiction. While designing TTMRA, Australia and New Zealand studied the 
centralized EU approach and found it inappropriate for the region. As Roger Wilkins, one of the architects of the system, explains:

[We] were familiar with the application of the [mutual recognition] concept in the ...European Union ... that ... involved an extensive bureaucratic administration, and its effectiveness was dependent on the issuing of directives to ensure that minimum essential standards would apply. Those directives were subject to a variety of interpretations and required close monitoring and enforcement. We wanted a more straightforward, low-maintenance approach in Australia, given the relative homogeneity of our states and territories. ${ }^{36}$

In short, the approach taken by Australia and New Zealand reflects the intention of the TTMRA architects to design a system that does not require new bureaucracy or continuous updates.

\section{The Recognition Process}

Under TTMRA, if a professional is registered to practice an occupation in one jurisdiction, that registration is the only proof needed should the individual seek registration for the same profession in another state or territory. ${ }^{37}$ Anyone in a registered occupation need only notify the registration authority of the jurisdiction in which they wish to work to be automatically deemed registered. ${ }^{38}$

The host-country authority approves, rejects, or defers the registration within 1 month. If an applicant does not hear from the authority within the month, that applicant is automatically registered. Once approved or rejected, the process of deemed registration ends ${ }^{39}$ (see Figure 13).

Under TTMRA, registration authorities may delay permanent registration for up to 6 months if: (1) incomplete or inaccurate information is provided in the application, (2) there is material change in the circumstances of the applicant, or (3) the applicant's occupation is not equivalent across jurisdictions. ${ }^{40}$

Any professional who disagrees with the decision made by an occupation registration authority under TTMRA can request that the Administrative Appeals Tribunal in Australia or the TransTasman Occupations Tribunal in New Zealand review his or her case. ${ }^{41}$ In such cases, the tribunals decide on an individual basis whether the professional should be registered in the other jurisdiction. ${ }^{42}$
36 Roger Wilkins, "Mutual Recognition: The First Eight Months," in The Australian Mutual Recognition Scheme: A New Approach to an Old Problem, eds. Tony Thomas and Cheryl Saunders (Melbourne: Centre for Comparative Constitutional Studies, University of Melbourne, 1995), cited in Australian Government Productivity Commission, Mutual Recognition Schemes, 45-46.
37 Australian Government Productivity Commission, Mutual Recognition Schemes, 64.

38 The Mutual Recognition Act 1992 (Commonwealth) and the Trans-Tasman Mutual Recognition Act 1997 (Commonwealth) define occupational registration to include "the licensing, approval, admission, certification (including by way of practising certificates), or any other form of authorisation, of a person required by or under legislation for carrying on an occupation." A similar definition is used in the Trans-Tasman Mutual Recognition Act 1997 (NZ).

39 Australian Government Productivity Commission, Mutual Recognition Schemes.

40 Ibid., 65

41 The Administrative Appeals Tribunal (AAT) provides for quasijudicial review of administrative decisions by the Australian federal government. It is neither a court nor part of the Australian court hierarchy; however, its decisions are subject to review by the Federal Court of Australia. The AAT was established by the Administrative Appeals Tribunal Act 1975[2] and started operation in 1976.

42 Australian Government Productivity Commission, Mutual Recognition Schemes, 71. 


\section{Figure 13: Recognition under the Trans-Tasman Mutual Recognition Arrangement}

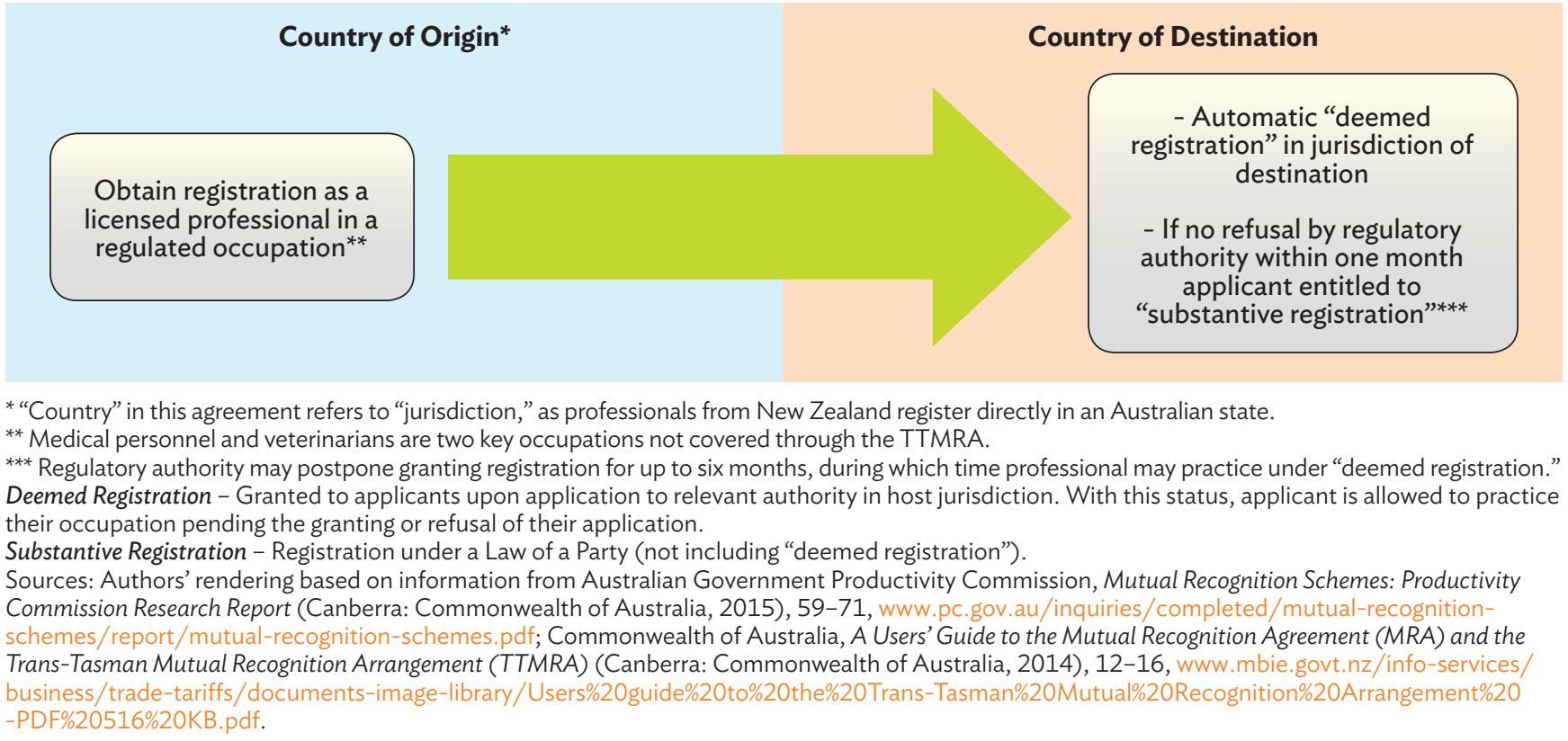

\section{Progress and Challenges in Implementation}

\section{a. Progress in Implementation}

Unlike the EU-PQD, data on the use of mutual recognition under TTMRA are limited - a drawback of its decentralized approach. The most recent official periodic TTMRA review, published in 2015, includes a survey of registration authorities across Australia and New Zealand..$^{43}$ The survey results suggest that, as in the European Union, the use of mutual recognition for registered occupations is both small and concentrated in the health-care professions. Authorities reported more than 15,000 uses of mutual recognition in 2014, or around $5 \%$ of all new registrations that year. ${ }^{44}$ While this proportion is much higher than the $0.14 \%$ found in the European Union, it also includes registrations between jurisdictions within Australia.

More than half of all TTMRA registrations were health professionals, with nurses and midwives comprising the largest shares. The trades (e.g., electricians and plumbers) made up a notable share, with nearly $15 \%$ of new registrations. ${ }^{45}$

\section{b. Challenges in Implementation}

TTMRA has been formally evaluated every 5 years since its inception. The 2003, 2009, and 2015 reviews concluded that the arrangement has been generally effective in reducing regulatory barriers between jurisdictions but that further improvements could be made, with a focus on three challenges:

\section{Some registration bodies have not implemented mutual recognition as intended. The 2015}

evaluation identified a number of instances when an individual registration body applied licensing requirements that directly contradicted the TTMRA. For example, applicants were asked to take a test, attend an interview, or complete additional training before in order to be registered. While such measures usually reflect concerns about consumer protection and public safety, they are also counter to the spirit of TTMRA. ${ }^{46}$
43 Ibid., 267-84.

44 Ibid., 130.
45 Ibid., 6.

46 Ibid., 220. 
Some regulators cannot fully implement TTMRA due to limited capacity. Registration authorities in both New Zealand and Australia face difficulties in determining the equivalence of occupations across jurisdictions-decisions that are key to identifying who can register. While TTMRA uses ministerial declarations to outline equivalence, as in the European Union, these declarations are not kept up to date-posing considerable challenges for regulators legally required to implement them. An initiative to update selected ministerial declarations commenced in May 2014, but progress has been slow.

\section{There is evidence of limited oversight and coordination, which exacerbates implementation}

problems. Although central bodies with either oversight or coordination duties exist, most have taken a hands-off approach or intervene only on rare and specific occasions.

The TTMRA experience suggests that the cost savings and other benefits of decentralization can be maximized in jurisdictions with comparable professional standards and deep-rooted relationships. In cases where there are significant regulatory differences, a lack of close monitoring makes it difficult to ascertain successes and failures, and correct them.

As Box 4 explores in more detail, the challenge for New Zealand and Australia is how to optimize the benefits of a decentralized structure without losing appropriate oversight.

\section{Box 4: The Trans-Tasman Mutual Recognition Arrangement Balancing Act: Retaining Decentralization while Maintaining Oversight}

Many parties play a role in the Trans-Tasman Mutual Recognition Arrangement (TTMRA) system. Although responsibility for oversight ultimately rests with the heads of government, it has been decentralized through the Cross Jurisdictional Review Forum (CJRF), with each jurisdiction represented on the forum by a government department.

Decentralization saves money and other resources, but makes monitoring and data collection difficult. A 2015 government evaluation of the TTMRA highlights deficiencies in the current governance of the arrangement, particularly limited CJRF capacity for monitoring. Still, there is no appetite to move toward a more centralized approach such as that found in the European Union; the evaluation concludes this "would be costly" and its "marginal benefits would be small."

Instead, evaluators see a two-pronged solution: keep the decentralized approach and enhance collective oversight, primarily by giving CJRF more specific responsibilities, timeframes, outputs, and reporting arrangements.

Source: Australian Government Productivity Commission, Mutual Recognition Schemes: Productivity Commission Research Report (Canberra: Australian Government Productivity Commission, 2015), www. pc.gov.au/inquiries/completed/mutual-recognitionschemes/report/mutual-recognition-schemes.pdf. 


\section{A Vertical Approach: Narrow Mutual Recognition Arrangements Limited to Specific Occupations and Sectors}

\section{T}

he comprehensive and sweeping nature of the EU-PQD and the Australia-New

Zealand TTMRA is rare. The majority of MRAs are limited to specific occupations or sectors. The bilateral MRA between the United States and Canada, for example, is for architects, while the regional MRA within CARICOM, an organization of 15 Caribbean nations and their dependencies, focuses on the arts, sports, and several regulated sectors. Similarly, the Washington Accord is a plurilateral agreement among engineering professional bodies from 15 countries in various regions.

As in the ASEAN region, the signatories of these three MRAs have deep economic links. For instance, the United States and Canada have the most significant bilateral trading relationship in the world, totaling $\$ 750$ billion in 2014 . The Washington Accord started out with a handful of countries, all with deeply integrated economies, before expanding membership. Its inclusion of several developing countries makes its experience extremely relevant for the ASEAN region. Many members of CARICOM, meanwhile, have operated in a regional single market since 1973. Then, in 2001, the Caribbean Single Market and Economy (CSME) liberalized the flow of goods and services throughout the region. ${ }^{47}$ Notably - and unlike in ASEAN-a regional court, the Caribbean Court of Justice, adjudicates complaints among CARICOM Member States.

47 Caribbean Community (CARICOM), "CARICOM Single Market and Economy (CSME): Overview," accessed 25 August 2016, http:// caricom.org/work-areas/overview/caricom-single-marke-andeconomy.
Given that ASEAN has till now taken an occupationand sector-specific approach to mutual recognition, these three MRAs are particularly instructive.

\section{A. Mutual Recognition Arrangement between Architectural Licensing Authorities of the United States and Canada}

\section{Background}

The MRA between the National Council of Architectural Registration Boards (NCARB) and the Canadian Architectural Licensing Authorities (CALA) recognizes the significant and substantial equivalence of the US and Canadian regulatory systems for the licensure and registration of architects. It provides for automatic recognition of licensed architects with permanent residence or citizenship in the United States or Canada. The MRA, signed in 2014, is not mandatory: constituent organizations of NCARB and CALA may choose to join or not. As of spring 2016, all 11 of the provincial architectural regulators in Canada were signatories, along with 42 US member boards of NCARB. ${ }^{48}$

The 2014 MRA is an update of the CanadaUS Inter-recognition Agreement, concluded a decade earlier and also focused on reciprocal licensure in architecture.

48 Author interview with Stephen Nutt, Chief Advisor to the CEO of the National Council of Architectural Registration Boards (NCARB), 30 May 2016. See more at NCARB, "NCARB's Advisor to the CEO Awarded International Medal," accessed 25 August 2016, www. ncarb.org/About-NCARB/Council-Organization/ManagementTeam/NuttAward.aspx\#sthash.zu8n7zco.dpuf. 
Figure 14: Mutual Recognition Arrangement between US and Canadian Architectural Licensing Authorities

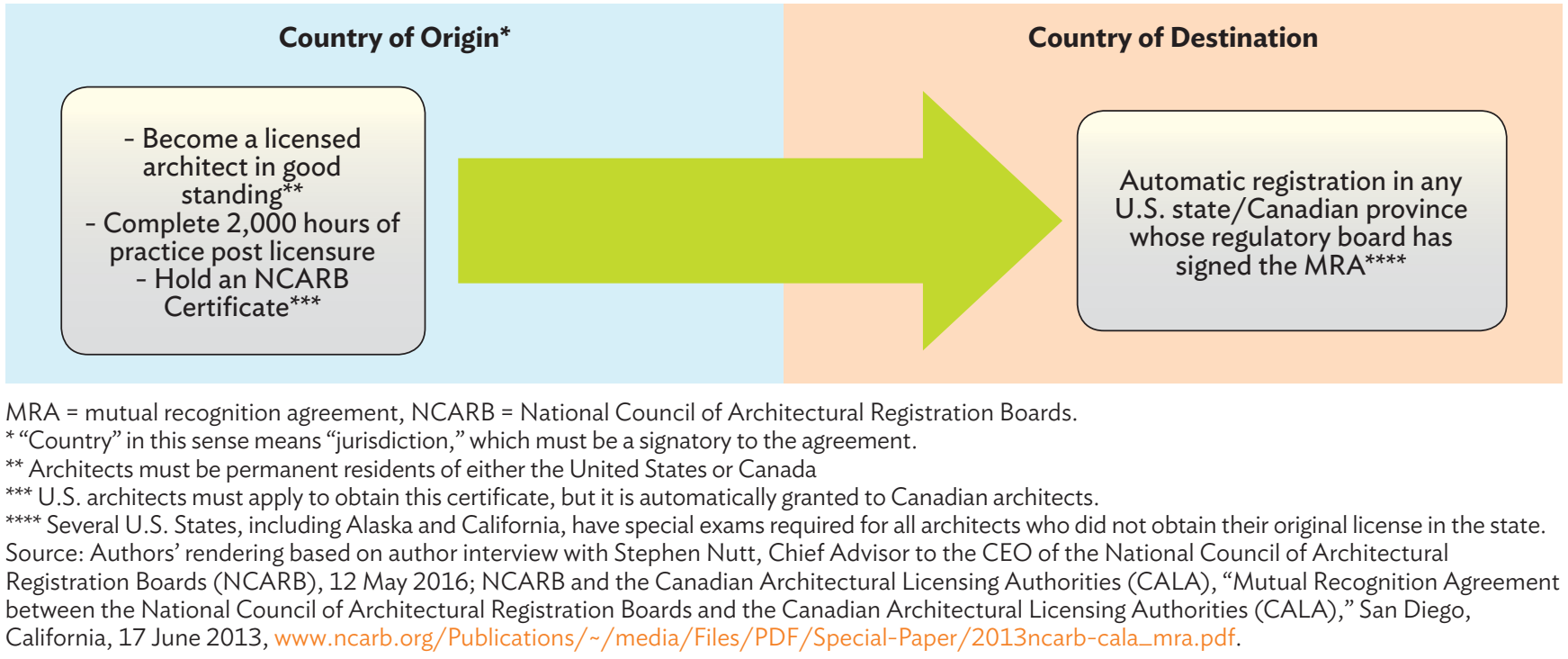

\section{The Recognition Process}

The recognition process under the MRA is quite straightforward, as Figure 14 illustrates. Canadian and US architects who are in good standing and have completed 2,000 hours of practice postlicensure (equivalent to about 1 year of experience) enjoy automatic recognition in any US state or Canadian province that has signed the MRA. In this system, architects are not required to provide educational transcripts, work experience dossiers, or exam scores when registering in a signatory jurisdiction in either country, thus easing the documentation burden on mobile professionals.

\section{Progress and Challenges in Implementation}

It is still too early to evaluate the impact of the new MRA. Between 2014 and 2015, 151 US registered architects and 79 Canadians received recognition, which is more than the average annual registration under the previous MRA. ${ }^{49}$ Under the Inter-recognition Agreement, 860 US architects and 330 Canadian architects registered through the system between 2003 and 2012. The real impact of the Inter-recognition Agreement may be its indirect effects. Specifically, Canadian architects began registering in the United States so that they could use the agreement to move between Canadian provinces. This contributed to the development of a federal licensure process for Canadian architects to ensure automatic portability of qualifications within the country. ${ }^{50}$ Clearly, MRAs can be critical in inspiring much needed changes close to home.

\section{B. The Washington Accord on Engineering}

\section{Background}

Like the MRA on architecture between Canada and the United States, the Washington Accord is focused on one occupation and driven by regulatory authorities; however, it does not provide for automatic recognition of qualifications. Signed in 1989, the accord only recognizes the "substantial equivalency" of the professional engineering undergraduate 
degree programs in signatory countries. Signatories accept these programs as fulfilling the education requirements for practicing engineering. ${ }^{51}$

\section{Although the six original signatories to this agreement were organizations in English-speaking countries-Australia, Canada, Ireland, New Zealand, the United Kingdom, and the United States-it has since expanded to include non-Anglophone countries such as Japan, the Republic of Korea, Malaysia, the Russian Federation, and Turkey.}

Signatories are responsible for periodically evaluating one another's accredited programs through a peer-review process to assess outcomes and guarantee that the academic training is substantially equivalent. ${ }^{52}$ They essentially agree to grant graduates of accredited programs in fellow signatory states the same recognition, rights, and privileges as those afforded to graduates of domestic accredited programs. Thus, the agreement facilitates the mobility of graduates across signatory jurisdictions and fosters cooperation among member countries. ${ }^{53}$

Another important feature of the accord is its inclusion of countries with various levels of development. The accord allows a signatory with inadequate development or capacity to, in effect, use the accreditation organization of another signatory. Further, a mentorship system pairs current signatories with provisional members to foster the sharing of knowledge and facilitate newcomers' entry into the accord.

\section{The Recognition Process}

To avail themselves of MRA benefits, professionals must first obtain an undergraduate diploma from a Washington Accord-accredited institution. Although the accord does not guarantee automatic recognition of professional qualifications, it fasttracks the process (as symbolized by the fast-forward sign in Figure 15). Engineers hoping to work abroad, however, must still meet whatever requirements the destination-country regulatory authority sets forth, such as work experience requirements, aptitude tests, and interviews.

In Australia, for example, Engineers Australia, which is a Washington Accord signatory, conducts skills assessments for prospective skilled migrants looking to move to Australia. ${ }^{54}$ Candidates with Accordaccredited qualifications can avoid a lengthier process involving the submission of a professional competency report. ${ }^{55}$ Meanwhile, Canadian professional engineering associations automatically recognize Washington Accord qualifications. ${ }^{56}$ Selected candidates may train under the supervision of a professional engineer until they meet a 4-year work experience requirement (which includes 1 year of Canadian work experience) and take a professional practice examination. ${ }^{57}$ In both countries, the accord facilitates the recognition of educational credentials as part of a multistage immigration process.

54 Applicants for a Points Tested Skilled Migration visa must nominate an occupation on the skilled occupations list and provide a skills assessment from the relevant authority. See Australian Government, Department of Immigration and Border Protection, "Skills Assessment and Assessing Authorities," accessed 3 June 2016, www. border.gov. $\mathrm{au} /$ Trav/Work/Work/Skills-assessment-and-assessing-authorities.

55 The accredited qualifications pathway is open to candidates with Australian, Washington Accord, Sydney Accord, or Dublin Accord qualifications; all others must apply through the nonaccredited qualifications pathway, which requires candidates to compile a competency demonstration report to prove their technical knowledge and professional experience. See Engineers Australia, "Migration Skills Assessment Booklet," January 2016, www.engineersaustralia.org. au/sites/default/files/shado/About\%20Us/Migration\%20Skills\%20 Assessment/msa_booklet-final-march-2016.pdf.

56 Candidates submit their transcripts to the provincial or territorial association for evaluation. See Engineers Canada, "Licensing in Canada," accessed 10 May 2016, http:/ / newcomers. engineerscanada.ca/licensing-canada; Engineers Canada, "Academic Information Tool," accessed 10 May 2016, http:/ /newcomers. engineerscanada.ca/academic-information-tool.

57 Provinces and territories may set additional requirements. 
Figure 15: Recognition Process of the Washington Accord on Engineering

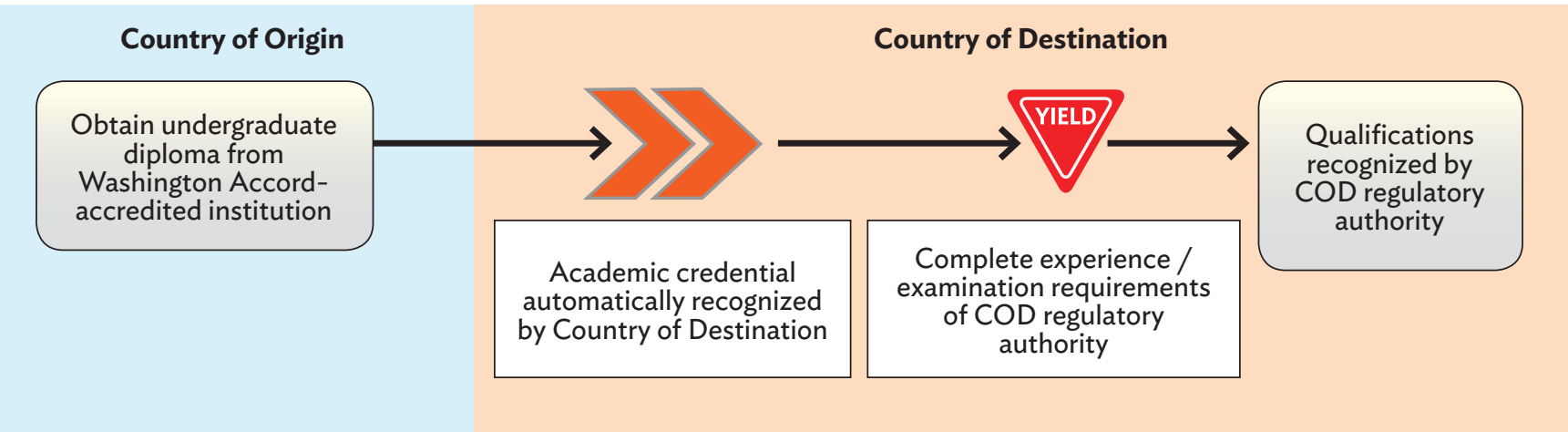

COD = country of destination

Source: Authors' rendering based on information from International Engineering Alliance, "Educational Accords: Washington Accord, 1989; Sydney Accord, 2001; Dublin Accord, 2002," 13 June 2014, www.ieagreements.org/Rules_and_Procedures. pdf?7432.

\section{Progress and Challenges in Implementation}

Today, the 15 nations under the accord recognize more than 7,000 programs. ${ }^{58}$ The accord has developed and matured over time. For instance, formal processes were created in 1995 for peer review of current signatories as well as for the admission of new members. The Sydney Accord for engineering technologists and Dublin Accord for engineering technicians were initiated in the early 2000s, and in 2007, the International Engineering Alliance (IEA) Secretariat was created to help signatories with the administration of the three accords. ${ }^{59}$

Two decades after the inception of the Washington Accord, membership expanded-first to accreditation organizations in Hong Kong, China and then South Africa and Japan in the 1990s; and by 2009 to Singapore and Taipei,China, as well as the Republic of Korea and Malaysia. ${ }^{60}$ Later, accreditation organizations from Sri Lanka, Turkey, the Russian Federation, and the People's Republic of China became signatories, ${ }^{61}$ while those from four developing countries-Bangladesh, India, Pakistan, and the Philippines - were granted provisional status. The mentoring of provisional members by existing signatories played a critical role in this expansion process.

8 IEA, 25 Years - Washington Accords (1989-2014).

59 Ibid.

60 Hanrahan, "The Washington Accord Past, Present, Future."

61 Ibid.

\section{Challenges Ahead}

The Washington Accord is likely to attract further signatories over time and contribute firsthand to cooperation on standards and good practices in the engineering and education fields. ${ }^{62}$ Two key challenges, however, threaten its continued evolution.

\section{First, the nonbinding nature of the accord can} lead to uneven recognition of programs between signatories. For example, while the UK Engineering Council recognizes the accredited bachelor's degrees of the US Accreditation Board for Engineering and Technology (ABET), the US board does not reciprocate. ${ }^{63}$ The accord's opt-in nature could also pose a problem as it further diversifies its membership.

\section{Second, differing traditions of engineering education provide substantial barriers to} expansion. Malaysia's experience with admission to the Washington Accord demonstrates the difficulties in expanding membership to countries with different traditions and standards in engineering education. At the time of application, Malaysia had a prescriptive-based system that detailed a checklist of

62 Hu Hanrahan, "The Washington Accord: History, Development, Status and Trajectory" (paper presented at the 7th Annual ASEE Global Colloquium on Engineering Education, Cape Town, October 19-23, 2008), www.asee.org/documents/conferences/ international/2008/Hanrahan-Accreditation-Track-WA-Paper.doc.

63 Arif Anwar and David Richards, "Is the USA Set to Dominate Accreditation of Engineering Education and Professional Qualifications?" Civil Engineering 166, no. CE1 (2013): 42-48. 
requirements engineering programs needed to meet when designing their curriculum. Only students who fulfilled these requirements received accreditation. However, as the Washington Accord signatories established outcome-based systems to standardize competencies in the profession, Malaysia had to conform to a fundamentally different system of engineering education. These changes included revising the engineering curriculum and setting up monitoring bodies to fulfill Washington Accord objectives. Many practitioners within Malaysia lobbied against admission to the accord, arguing that the then-existing system had worked thus far, and that "acquiescing to the demands of the Washington Accord was submitting to neo-colonial pressures from Western powers."64

The government of Australia, which acted as lead mentor, and the United States and Hong Kong, China, which provided technical support, were instrumental in Malaysia's accession to the accord years later.

\section{Caribbean Community Skills Certificate Scheme}

\section{Background}

Unlike the Washington Accord and the USCanada MRA, which focus on one occupation, the CARICOM Skills Certificate Scheme facilitates intraregional mobility for university graduates working in any of several specified occupations (e.g., art, music, media, and sports). Additional certification is offered through the Caribbean

64 Hassan Basri, A. B. Che Man, Wan Hamidon Wan Badaruzzaman, and Mohd Jailani Mohd Nor, "Malaysia and the Washington Accord: What It Takes for Full Membership," International Journal of Engineering and Technology 1, no. 1 (2004): 64-73.
Vocational Qualification (CVQ) program, designed to provide mobility for individuals with no higher education. The CVQ program also sets common standards, thereby helping employers to assess skills and quantify the value of apprenticeships and prior work experience. ${ }^{65}$

The recognition is only partial: national policies may require additional measures before professionals can practice in the country of destination. Moreover, possession of a skills certificate neither ensures a right to residence nor access to local labor markets. ${ }^{66}$ Notably, CARICOM has created several institutions to monitor and facilitate the mobility of skilled professionals. The first and most powerful of these bodies is the Caribbean Court of Justice, which functions as the enforcer of CARICOM rules and regulations, including those outlined in the CSME and pertaining to mutual recognition. ${ }^{67}$ As a result, the CARICOM skill recognition arrangement is binding on members that have joined the scheme, unlike the US-Canada MRA on architecture and the Washington Accord.

\section{The Recognition Process}

Professionals interested in taking advantage of the scheme can obtain the skills or CVQ certification in their home country prior to departure, or when they arrive at destination. If applicants choose to apply in the country of destination, they have 6 months to submit the proper paperwork. Once the application has been approved, migrants receive their skills certificate, along with rights to permanent residency (see Figure 16).

65 National Training Agency, "Overview - What Is the CVQ?" accessed 25 August 2013, http://ntatvetcentre.org/cvq_overview.aspx.

66 Sonja Schröder, "Regional Approaches in Managing Migration: A Comparative View" (paper presented at Migration: A World in Motion, A Multinational Conference on Migration and Migration Policy, Maastricht, the Netherlands, 18-20 February 2010), www. umdcipe.org/conferences/Maastricht/conf_papers/Papers/ Regional_Approaches_in_Managing_Migration.pdf.

67 Raghunath Mahabir, "Migration of Skilled Personnel in the CSME: A Case Study of Trinidad and Tobago," Social and Economic Studies 56, no. 4 (2007): 207-39. 
Figure 16: Recognition under the Caribbean Community Mutual Recognition Arrangement

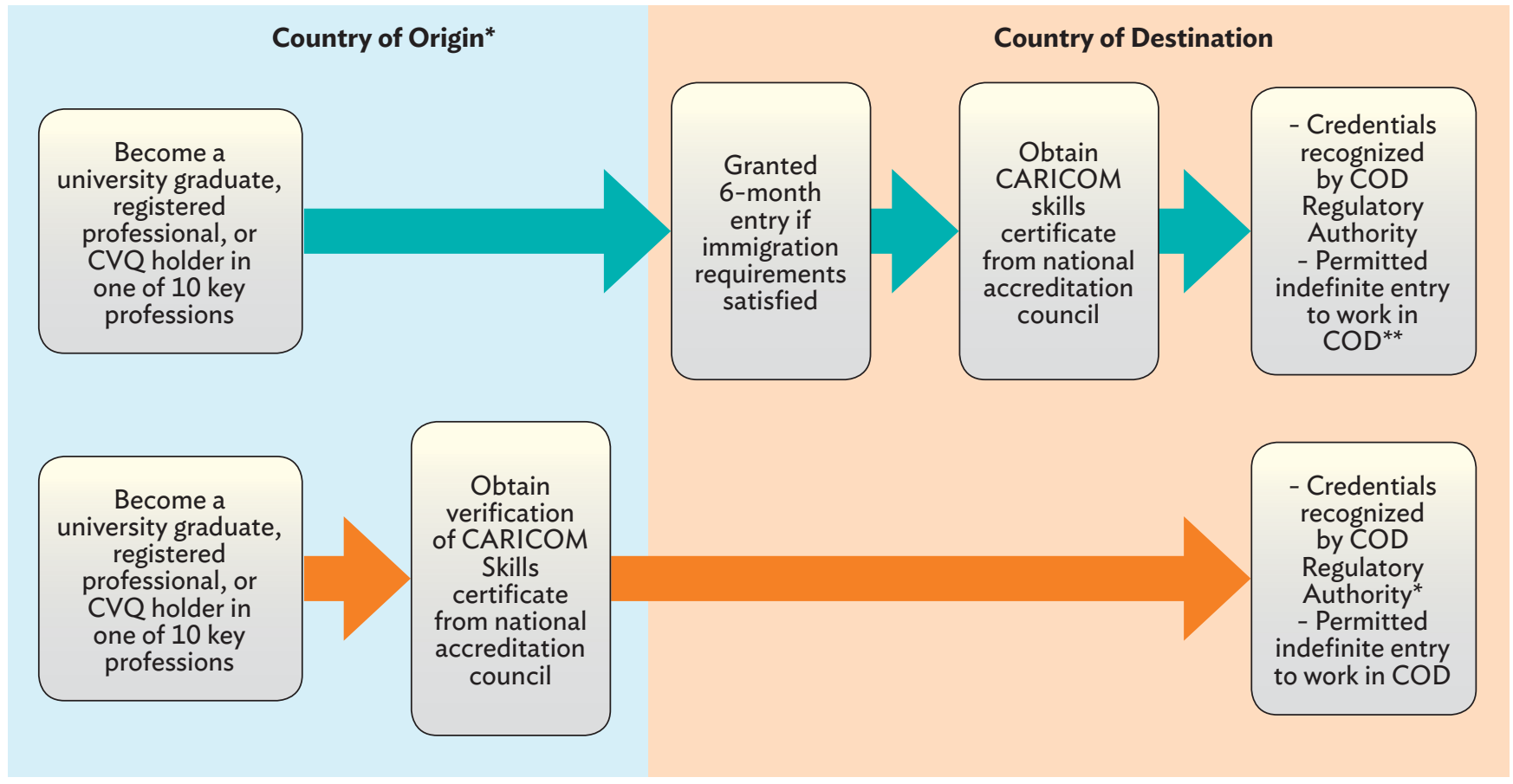

CARICOM = Caribbean Community, $C O D=$ country of destination, $C V Q-$ Caribbean Vocational Qualification, MRA = mutual recognition arrangement.

${ }^{*}$ Credentials recognized pending verification of documents by the COD Regulatory Authority.

** Professional nurses are included as entitled to indefinite entry to work without further examination or compensatory measures.

10 categories for recognition - University graduates, Media workers, Sportspersons, Artistes, Musicians, Professional Nurses, Qualified Teachers, Artisans with CVQ, Holders of Associate Degrees or equivalent qualifications, Household Domestics with CVQ or equivalent qualification. Sources: Authors' rendering based on information from Trinidad and Tobago Ministry of National Security, Immigration Division, "CSME Caricom Single Market and Economy," accessed 21 June 2016, www. immigration.gov.tt/Services/CSME.aspx; CARICOM Single Market and Economy (CSME) Unit, "CSME_Freedom of Movement," 2 April 2014, www.csmeonline.org/news/video/csme-freedom-of-movement; Government of the Republic of Trinidad and Tobago, Ministry of Foreign and CARICOM Affairs, "CSME," accessed 21 June 2016, https://foreign.gov.tt/services/ csme/; CARICOM, Caribbean Community (Free Movement of Skilled Persons) Act, 15 July 1997, http://moj.gov.jm/sites/default/files/laws/ CCFMSP\%20Act.pdf; Barbados Accreditation Council, "Overview," accessed 21 June 2016, https://bac.gov. bb/Services/SkillsCertificate/.

\section{Progress and Challenges in Implementation}

It is difficult to ascertain how well the program has been implemented. CARICOM does not release the number of skills certificates awarded annually, and national statistics agencies do not have a standard way of reporting CSME immigration statistics. However, judging from the limited information shared with the media, approximately 14,000 skills certificates had been issued as of $2014 .{ }^{68}$

68 Kaieteur News, "14,000 CARICOM Skills Certificates Issued-Says CARICOM Secretary General," Kaieteur News, 11 November 2014, www.kaieteurnewsonline.com/2014/11/11/14000-caricom-skillscertificates-issued-says-caricom-secretary-general/.
Despite this progress, only 12 of the 15 CARICOM members had agreed to participate in the arrangement 10 years after it was signed, which illustrates the challenges of achieving full implementation. Beginning in 2006, CARICOM announced its renewed commitment to expand and strengthen the skills certification process by extending automatic recognition of skills to more professionals and broadening the professions eligible for skills certification. ${ }^{69}$ Little has been accomplished at the regional level since, but

69 Norman Girvan, Towards a Single Economy and a Single Development Vision (Greater Georgetown, Guyana: CARICOM Secretariat and the Special Task Force on the Single Economy, 2006), 31-32, www.caribank.org/uploads/publications-reports/ research/conference-papers/regional-conference-on-csme/ GirvanTowardsSingleEconomy[1].pdf. 
countries have adapted individual laws pertaining to mobility and skills recognition. Jamaica, for instance, has discussed expanding the categories that qualify for the skills certificate.

Another limitation of the CARICOM arrangement is the unequal rights accorded to migrants moving within the region. Skilled migrants, for instance, lack the legal protections afforded in other mobility regimes such as the European Union. ${ }^{70}$

Institutional deficiencies have also hindered full implementation of the scheme. For instance, assessing application in member countries without national accreditation bodies ${ }^{71}$ has been assumed by countries with such bodies, prompting concern that CARICOM policies are being administered "unevenly" and that "national policy is superseding regional policy."72

Problems of uneven MRA implementation at the national level are not unique to CARICOM, as the earlier discussion of the EU-PQD and TTMRA reflects. Clearly, more effective enforcement of existing rules is important; in its absence, full MRA implementation is extremely difficult, if not impossible.
70 Patrick Kendall, "Globalisation, Trade Liberalisation and the CARICOM Single Market and Economy" (paper presented at the 39th Annual Monetary Studies Conference, Belize City, 6-9 November 2007), http://new.ccmfuwi.org/files/publications/ conference/947.pdf.
71 Mahabir, "Migration of Skilled Personnel in the CSME."

72 Ibid., 216, 220. 


\section{Umbrella-Agreement Approach: Detailed Guidelines for Future Mutual Recognition Arrangements}

nstead of negotiating an MRA, policymakers may opt to negotiate an umbrella agreement that outlines key terms and conditions of a mutual recognition process, leaving ample room for further MRA negotiations.

As with the MRAs reviewed thus far, countries that have signed umbrella agreements have deep economic links and shared goals. The FranceQuébec Accord of 2008 benefited from the long-standing historical, cultural, and linguistic ties between France and the Canadian province of Québec. ${ }^{73}$ Growing skills shortages driven by a rapidly shrinking working-age population and an aging society ${ }^{74}$ underpinned the Québec government's push for the agreement. The accord was expected to attract more professionals from France to fill the demand for skills in the labor market in Québec and vice versa.

Similarly, the Asia-Pacific Economic Cooperation (APEC) Architect Project Framework grew out of APEC, an economic forum promoting free trade throughout the Asia-Pacific region, established in 1989 amid evidence of growing interdependence among its 21 members. ${ }^{75}$ The project encompasses 14 APEC members, including some of the largest

73 The Canadian province of Québec was founded by the French in the 16th century, and was a French colony for three centuries. Its linguistic, cultural, and political ties with France remain strong in the context of Québec's determination to maintain its linguistic and cultural specificity, and a great degree of administrative autonomy in Canada.

74 At that time, the rate of aging in Québec was second only to Japan among world economies. It is forecast that by 2020 Québec will have to fill 1.4 million additional job vacancies.

75 Asia-Pacific Economic Cooperation (APEC), "What is Asia-Pacific Economic Cooperation?" accessed 6 July 2016, www.apec.org/ About-Us/About-APEC.aspx. and most internationally active economies: the United States, the People's Republic of China, Japan, and Australia.

\section{A. The France-Québec Accord}

\section{The Framework}

Regulatory bodies are powerful actors in both France and Québec. They enjoy full autonomy in Québec, while regulatory authority is shared between the line ministry and the appropriate professional body in France. Thus the active buy-in of regulatory bodies is necessary for MRAs to be negotiated, and, more crucially, implemented.

Within this context, the France-Québec Accord has set out a common framework and procedure for the conclusion of occupation-by-occupation MRAs. It defines in clear terms the principles and objectives of engaging in mutual recognition, as well as the main criteria of the procedure that must be followed across the different professions and trades. At the same time, the accord creates leeway for regulatory bodies in each profession and trade to negotiate their own specific eligibility requirements for recognition (see Figure 17).

The accord allows for the automatic recognition of licenses when there is overall equivalence in the scope of practice and the formal qualifications or learning program required for getting a license. The scope of practice is equivalent when there are no substantial discrepancies in training in the two territories. For instance, if one or several activities covered by a regulated profession or trade in one territory do not constitute part of the corresponding 
Figure 17: Recognition Framework under the France-Québec Mutual Recognition Arrangement

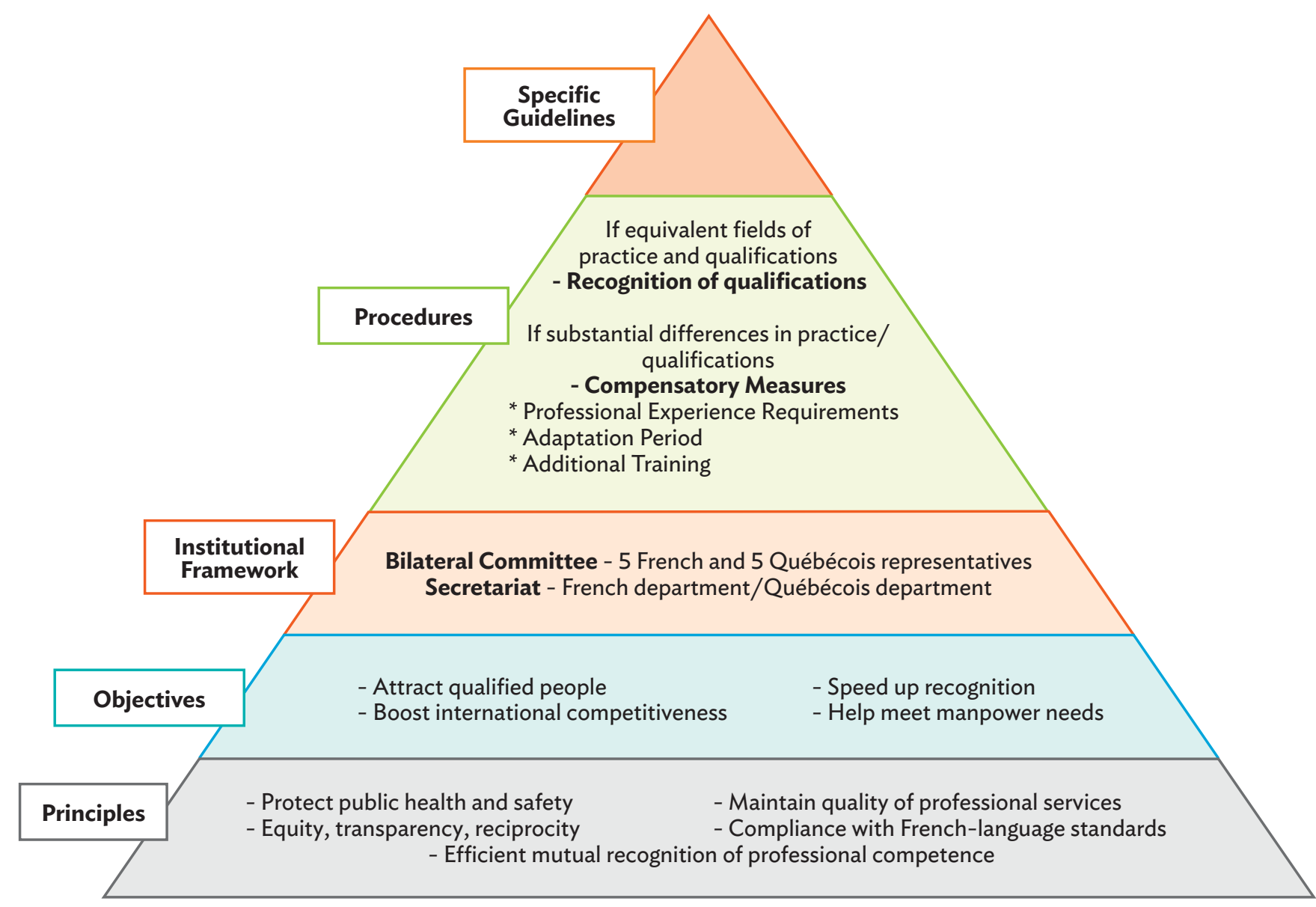

Sources: Authors' rendering based on information from Relations internationales et Francophonie Québec, "Detailed Information about the Agreement," accessed 21 June 2016, www.mrif.gouv.qc.ca/en/ententes-et-engagements/ententes-internationales/reconnaissance-qualifications/ entente-en-details; Ministère des Relations internationales et de la Francophonie (MRIF), "France-Québec Agreement on the Mutual Recognition of Professional Qualifications: Common Procedure for the Recognition of Professional Qualifications (Diagram)," accessed 21 June 2016 , www. mrif gouv.qc.ca/Content/documents/en/procedure_commune_entente_qualif_prof_FrQc_en.pdf; Le Premier Ministre du Québec et Le Président de la République Française, "Entente entre le Québec et La France En Matière de Reconnaissance Mutuelle des Qualifications Professionelles," Québec, Canada, 17 October 2008, www. mrif.gouv.qc.ca/Content/documents/fr/2008-12.pdf.

profession or trade in another, then the scope of practice is not considered equivalent. The qualifications and learning programs are also not considered equivalent when their duration differs by at least 1 year.

In the case of nonequivalence, the accord allows regulatory authorities to grant partial recognition, and to set out in each MRA clear rules for the compensatory measures that foreign-qualified professionals need to fulfill to obtain full recognition. In this regard, the accord aims to strike the right balance between (1) the principle of protecting public health and safety and (2) the objective of offering foreign-qualified workers access to practice. Under the terms of the accord, compensatory measures should be commensurate to the gaps that need to be filled, and should not impose excessive burdens on the candidates or delay their access to full and independent professional practice. The accord states that regulators should impose reasonable adaptation periods and allow foreignqualified candidates to practice their profession at a lower level and under supervision while waiting for registration. Aptitude tests may also be required; additional training is the last resort. 


\section{Progress and Challenges in Implementation}

Since the accord entered into force in 2009, more than 70 MRAs have been concluded and implemented in regulated professions (including accountants, architects, dentists, doctors, engineers, lawyers, and nurses), trades (such as in the construction and restaurant sectors), and functions (insurance and real estate agents). ${ }^{76}$ By the end of 2014, 1,727 professionals registered in France were allowed to practice in Québec. The number of Québec professionals who obtained recognition in France was much smaller, at 230 . This primarily reflects the different sizes of the two populationsthe Québec population accounts for less than onesixth that of France.

The framework has led to diverse MRA arrangements that reflect the specific requirements and context of each occupation. Automatic recognition was adopted in the majority of professions and trades; roughly one-third provide for partial recognition of licenses. In most cases, on-the-job adaptation periods-often accompanied by some bridge training - are required to make up for differences in the scope of practice and training standards. Reflecting the spirit of the accord, additional testing and full training have been avoided as much as possible. Bridge training presents a much more efficient and practical option than requiring full training because it allows professionals to train only to remedy gaps in specific skills and knowledge.

76 Ministère de L'Immigration et Communautés Culturelles of Québec, Liste des professions pour lesquelles un arrangement de reconnaissance mutuelle a été signé (Québec: Ministère de L'Immigration et Communautés Culturelles, 2014), www.immigration-quebec.gouv. qc.ca/publications/fr/arm/Liste-professions-ARM.pdf; Ministère de L'Immigration et Communautés Culturelles of Québec, Liste des métiers pour lesquels un arrangement de reconnaissance mutuelle a été signé (Québec: Ministère de L'Immigration et Communautés Culturelles, 2013), www.immigration-quebec.gouv.qc.ca/ publications/fr/arm/Liste-metiers-ARM.pdf; Ministère de L'Immigration et Communautés Culturelles of Québec, Liste des functions du domaine des assurances, des valeurs mobilières et des instruments financiers pour lesquels un arrangement de reconnaissance mutuelle a été signé (Québec: Ministère de L'Immigration et Communautés Culturelles, 2011), www.immigration-quebec.gouv. qc.ca/publications/fr/arm/Liste-fonctions-ARM.pdf.
Some compensatory measures are not reciprocal, leading to asymmetric licensing requirements. For instance, to get licensed in France, Québec pharmacists are required to take a chemistry exam, a condition not required of their French counterparts registering in Québec. Québec has agreed to this asymmetric requirement because the scope of practice for the profession in France, where pharmacists may prepare pharmaceuticals, is broader than in Québec.

The reverse holds in architecture. Québectrained and -licensed architects can get automatic recognition in France. However, Québec imposes additional requirements for French architects: 3 years of professional experience and a diploma from a French educational institution. French architects who do not meet these requirements have the option of passing Québec's licensing exam for architects, or working for 1 year in collaboration with and under the supervision of a Québec-licensed architect.

\section{Nursing offers another interesting case of} nonreciprocal measures. In the first version of the France-Québec MRA on nursing, recognition of registered nurses was conditional on a period of supervised practice combined with a 75-day bridging course in the host territory. ${ }^{77}$ However, in 2014, the French regulator, faced with the difficult and resource-intensive task of designing a specific bridging module for Québec nurses, determined that the differences in nursing qualifications were not large enough to justify such an investment. As a result, an amendment to the MRA made recognition automatic for Québec-qualified nurses in France, while the recognition of French-qualified nurses in Québec has remained subject to the adaptation period. ${ }^{78}$

77 Gouvernement du Quebéc, Arrangement en vue de la Reconnaissance Mutuelle des Qualifications Professionnelles entre L'Ordre des Infirmières et Infirmiers du Québec et la Ministre de la Santé et des Sports et L'Ordre National des Infirmiers de France (Quebéc: Gouvernement du Quebéc, 2010), www.immigration-quebec.gouv.qc.ca/publications/fr/arm/ ARM-infirmieres.pdf.

78 Gouvernement du Quebéc, Avenant à L'Arrangement en vue de la Reconnaissance Mutuelle des Qualifications Professionnelles des Infirmières et Infirmiers Signé le 13 Août 2010 (Quebéc: Gouvernement du Quebéc, 2014), www.immigration-quebec.gouv.qc.ca/ publications/fr/arm/Avenant-infirmieres.pdf. 
Indeed, providing an adequate offer of supervised work and reasonable adaptation periods for foreignqualified professionals can be challenging. If the adaptation period is not waived, as in the case of French doctors in Québec, governments can directly help professionals find sponsors and even pay the costs associated with the adaptation period (see Box 5).

\section{B. Asia-Pacific Economic Cooperation Architect Project}

\section{The Framework}

\section{Unlike the France-Québec Accord, the APEC} Architect Project Framework specifies the eligibility requirements needed to practice as an architect in the APEC region. Participating economies may then enter into bilateral or multilateral MRAs following the eligibility requirements identified in the framework. Currently 14 economies are part of the framework: Australia; Canada; the People's Republic of China; Hong Kong, China; Japan; the Republic of Korea; Malaysia; Mexico; New Zealand; the Philippines; Singapore; Taipei,China; Thailand; and the United States. ${ }^{79}$

\section{Professionals with a 4-year degree from an} accredited architectural education program, prelicensing experience of 2 years, and a minimum of 7 years' experience as a registered or licensed architect are eligible to apply for recognition. ${ }^{80}$ The framework allows regulatory bodies in destination countries to adopt compensatory measures as long as they are fully transparent. For instance, APEC architects can gain recognition through an interview called the "Domain Specific Assessment." ${ }^{1}$ In such a fast-track procedure, practical experience

79 APEC, “APEC Architect Framework," accessed 6 July 2016, http:// apecarchitects.org/index. php?option=com_content\&view=article\&id $=62 \&$ ltemid $=74$.

80 APEC, "Registration as an APEC Architect," accessed 6 July 2016, http://apecarchitects.org/index.php?option=com_content\&view=ar ticle\&id $=63 \&$ Itemid $=76$

81 APEC, APEC Architect Operations Manual (Vancouver: APEC, 2014), 16, www.apecarchitects.org/images/pdf/repairs/operationsmanual-2014.pdf; Architects Accreditation Council of Australia (AACA), APEC Architect Supplementary Assessment Process (Canberra: AACA, 2013), 4, www.aaca.org.au/wp-content/uploads/2013/10/ October-2013-Domain-specific-assessment-process1.pdf.

\section{Box 5: Helping Professionals Undertake Compensatory Measures: The Case of French Doctors in Québec}

Offering foreign professionals an on-the-job adaptation period is an international best practice. Such a period offers immediate immersion in the host country's professional environment and the possibility of working while training to meet licensing requirements. As such, it facilitates the swift and effective recognition of foreign professional qualifications. However, in practice, foreign-qualified professionals may find it difficult to obtain adequate offers of supervised work and adaptation periods.

For instance, the France-Québec mutual recognition arrangement (MRA) on medical professions requires that French-qualified doctors complete a 3-month adaptation period in a Québec hospital before receiving full recognition to practice in Québec. While this is not a burdensome requirement, there are limited opportunities for adaptation and training positions. Doctors and health professionals in Québec are overstretched as it is, and few have time to supervise the work of French candidates. This discourages foreign professionals, who decide not to seek recognition. Others may be unwilling to pay the cost of the adaptation period, as agreed in the MRA.

Conscious of these difficulties, Recrutement Santé Québec (RSQ), an agency of the Ministry of Health and Social Services, supports French doctors who are seeking recognition under the MRAs. It helps them obtain the sponsorship of a local hospital, and-of critical importance for those who aren't already in Québec-an immigration permit. It also offers French doctors financial support of up to CAD 12,000 (US $\$ 9,141$ ) to pay for their adaptation periods and recognition procedures.

Sources: Collège des Médecins du Québec, Ministère de la Santé de la République Française, Conseil National de l'Ordre des Médecins de France, "Arrangement en Vue de la Reconnaissance Mutuelle des Qualifications Professionnelle des Médecins, " 27 November 2009, www.immigrationquebec.gouv.qc.ca/publications/fr/arm/ARM-medecins. pdf; expert commentary at ADB-MPI Roundtable of High-Level Experts, "Achieving Skill Mobility in the ASEAN Economic Community: Challenges, Opportunities, and Policy Implications," Bali, Indonesia, 12 May 2015; Santé et Services sociaux Québec, "Arrangement de reconnaissance mutuelle (ARM) des compétences Québec-France pour les médecins," accessed 20 April 2016, www. msss.gouv. qc.ca/sujets/organisation/medecine/rsq/index.php?armquebec-france. 
and examination requirements in the host country are waived..$^{82}$ Instead, APEC architects pay a registration fee and complete the interview with host country architects who assess applicants' knowledge of local principles. ${ }^{83}$

The framework also creates a governance system, including an online register, an APEC-level central council, and national monitoring committees. ${ }^{84}$ An APEC register records the names of architects who meet the eligibility requirements; monitoring committees in each participating economy assess applicants. A central council, composed of one monitoring committee member from each country, has ultimate responsibility for managing the framework (see Figure 18).

\section{Figure 18: Framework for Recognition under the Asia-Pacific Economic Cooperation Architect Reciprocal Recognition Framework}

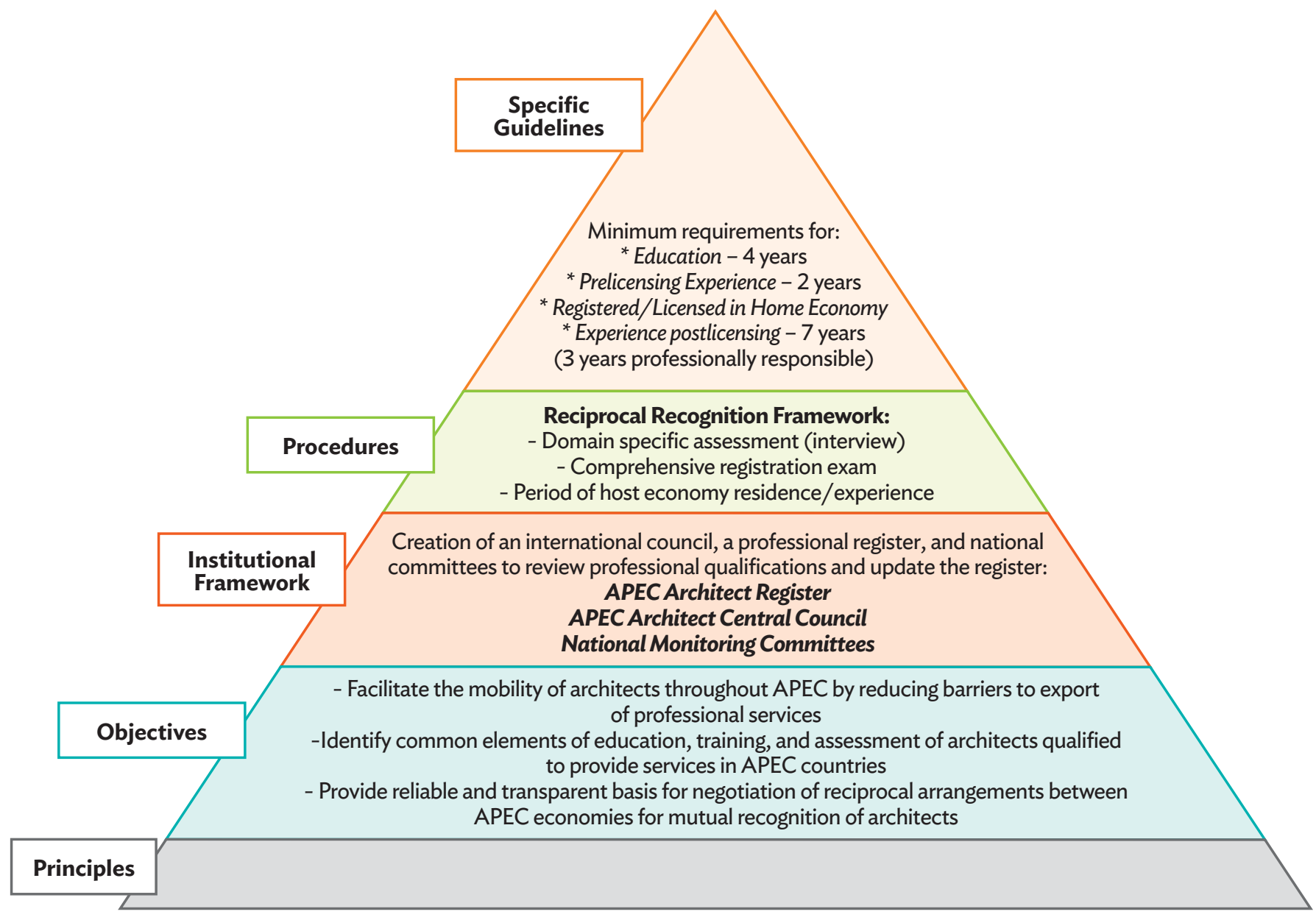

APEC = Asia-Pacific Economic Cooperation

Source: Authors' rendering based on information from APEC, APEC Architect Operations Manual, 2014 (Vancouver: APEC, 2014), www.apecarchitects.org/images/pdf/repairs/operations-manual-2014.pdf.

82 AACA, APEC Architect Supplementary Assessment Process.

83 In Australia, a dossier submission including the architect's past work is encouraged, and APEC architects are also required to submit original documents of their educational credentials. See AACA, APEC Architect Supplementary Assessment Process. 


\section{Progress and Challenges in Implementation}

The APEC Architect Project Framework has had some success in encouraging its members to negotiate MRAs. Table 2 outlines all bi-and trilateral MRAs signed between 2007 and 2015 by Australia, New Zealand, Canada, Singapore, Japan, and Taipei,China. ${ }^{85}$

Despite the success of the project, very few architects have registered at destination. For instance, although Australia participated in four such arrangements, only five Australian architects had registered as of May 2016. ${ }^{86}$ The head of the Australian Regulatory Board speculated that there was little interest among Australian architects for two reasons: the MRAs did not include key destinations, such as the United States, and working overseas is possible through other channels. ${ }^{87}$

Ultimately, the infrequent use of the MRAs has discouraged other members of the APEC Architect Project from negotiating further arrangements. A senior NCARB official interviewed for this report explained that the effort to negotiate such arrangements outweighs the benefits if only a handful of people register. ${ }^{88}$

Table 2: Bi- and Trilateral Arrangements Implemented under the Asia-Pacific Economic Cooperation Architect Project

\begin{tabular}{|l|c|c|}
\hline Member Economies & Date Signed & Registrations \\
\hline Taipei,China - Australia & 16 September 2007 & 0 \\
\hline Japan - Australia & 1 July 2008 & 2 (Japan $\rightarrow$ Australia) \\
\hline Japan - New Zealand & 14 July 2009 & 0 \\
\hline Singapore - Australia - New Zealand & 10 October 2010 & $\begin{array}{c}\text { (Singapore } \rightarrow \text { New Zealand) } \\
\text { 3 (Singapore } \rightarrow \text { Australia) }\end{array}$ \\
\hline Taipei,China - New Zealand & 3 October 2012 & 0 \\
\hline Australia - Canada - New Zealand & 18 February 2015 & 1 (Australia $\rightarrow$ Canada) \\
\hline
\end{tabular}

APEC = Asia-Pacific Economic Cooperation

Source: APEC, "Bilaterals," accessed 26 May 2016, www.apecarchitects.org/index.php?option=com_content\&view=article\&id=84\&ltemid=102.

85 APEC, "Bilaterals," accessed 26 May 2016, www.apecarchitects.org/ index . php?option $=$ com_content\&view $=$ article\&id $=84 \&$ ltemid $=102$.
86 Author interview with Kate Doyle, CEO of the Architects Accreditation Council of Australia (AACA), 27 May 2016.

87 Nathan Johnson, "First Australian Architect Registers in Canada under New Mutual Recognition Arrangement," Architecture \& Design, 20 July 2015, www.architectureanddesign.com.au/news/first-australianarchitect-registers-in-canada-und.

88 Author interview with Stephen Nutt, Chief Advisor to the CEO of NCARB, 12 May 2016. 


\section{Five Key Lessons for the ASEAN Region}

\section{T} hese and other experiences with various types of MRAs offer a sobering reality for ASEAN policymakers tasked with accomplishing similar objectives. But there is some good news: the ASEAN region need not start from scratch. It can learn from the experiences of other regions, especially from practices that work well on the ground. Indeed, the design and implementation of the MRAs highlighted in this report offer many insights and opportunities relevant to ASEAN. Five of these are highlighted below.

First, the harmonization of training standards is a long process that requires both relentless commitment and enormous resources to achieve and, even more importantly, to maintain. As seen in the European Union, the harmonization of training is very resource- and time-intensive and takes sustained political will. Negotiations to establish harmonized standards for health professionals and architects took decades to complete. Malaysia's effort to harmonize its engineering curriculum with the Washington Accord required nothing less than a fundamental shift.

Once training standards are harmonized, updating the system to reflect changes in education or training requires additional negotiations and even more resources. Even in the resource-rich European Union, existing rules on harmonized minimum conditions are not regularly reviewed; some have remained unchanged for 35 years. It is therefore not surprising that New Zealand and Australia, as well as France and Québec, did not take the European Union's long and intense route to harmonization.
Within ASEAN, only the MRA on tourism encompasses harmonized training, and the process took more than a decade to complete. Although the current focus is on rolling out harmonized training modules at the local level, sooner or later ASEAN will face the equally daunting task of updating the training requirements to meet the ever-changing demands of the tourism sector's labor market.

On the upside, as seen in the European Union, mobility rates are highest among professionals with harmonized training requirements. Clearly, there could be great value in pursuing harmonization in sectors and occupations that are extremely relevant to regionally set goals-as long as the parties involved are aware of and commit to finding and investing the required resources.

\section{Second, centralized systems require enormous} resources to implement, while a decentralized approach, although less resource intensive, is difficult to monitor. Even after the European Union streamlined its many different pathways to recognition, implementation remained difficult. Professionals were confused about which pathway to use, and the centralized information (delivered via contact points and regional information platforms) failed to fill the information gap adequately or efficiently. Keeping a centralized system updated is almost as resource intensive as creating it.

The approach of the New Zealand-Australia TTMRA is less resource intensive: regulators do not need to create new structures but instead 
utilize what already exists at the local level. Ensuring compliance, however, is difficult. The TTMRA experience shows that decentralization is particularly problematic in cases where buy-in from regulatory authorities is low. Registration bodies may unilaterally decide to apply licensing requirements contrary to the spirit of the MRA.

A decentralized approach also makes it difficult to monitor and address cases of unequal access. As seen in CARICOM, skilled migrants can be discriminated against without the legal protections afforded to natives. Where a regional governance structure is not well developed, professionals depend on the will and capacity of local institutions for support, the quality of which can vary greatly. ${ }^{89}$

\section{Third, partial recognition can only be effective} if guidelines for compensatory measures are clear and not unnecessarily onerous. Partial recognition is more cost-effective than laying down ideal conditions for automatic recognitionas long as there are clear and commensurate criteria for bridging qualification gaps. Clear criteria reduce the risks posed by the case-by-case assessments of national regulatory authorities:

decisions may be arbitrary, making the recognition system unpredictable. As in the European Union, authorities enjoy considerable leeway in in identifying what counts as a gap in training, and whether to require compensation measures. Some regulators will abuse their discretion.

Unnecessarily complicated systems can also lead to serious implementation problems. The complex documentation and other requirements of the $\mathrm{EU}$ general system make it cumbersome and timeconsuming. The France-Québec Accord shows that licensing conditions are more effective if they are laid out pragmatically and if they focus on bridging qualification gaps fairly and efficiently.

89 Kendall, "Globalisation, Trade Liberalisation and the CARICOM Single Market and Economy."
The asymmetric requirements seen under this accord are especially instructive for ASEAN member states as they move forward with implementing MRAs in the health sector. For instance, recognition requirements for professionals licensed in ASEAN countries that share similar training levels and scopes of practice can be less severe than those for professionals licensed in other countries. This pragmatic approach may help move the implementation of MRAs forward without waiting for training and qualification requirements to converge throughout the ASEAN region-a process that would take many years, if not decades.

Fourth, umbrella agreements offer a promising alternate approach to MRA negotiations, but only if there is political will at the highest levels to support regulatory bodies and professional associations. Indeed, the success of the FranceQuébec Accord was driven by unstinting political will at the highest levels of governance. Both governments actively encouraged regulatory bodies to conclude MRAs by sponsoring local counterparts to visit each other's territory and share information on scopes of practice and training requirements, and most importantly, to build trust.

\section{To conclude, MRAs are living documents that require continual revision, improvement, and renegotiation. The EU MRAs and TTMRA} have evolved through regular evaluation and monitoring. Signing an MRA is just the first, critical step; the ultimate goal should be to fully implement the arrangement, scale it up when appropriate, and garner sustained political will at the highest levels of government. MRAs are most beneficial when there is close coordination at all the necessary levels of governance, when country champions set deadlines and bring bureaucracies in tow, and where there is continued and meaningful engagement with an ever-broader set of actors: employers, professionals interested in exploring mobility options, and professional associations that can understand and explain the benefits of MRAs to their members. 


\section{A. Reinventing MRAs for the 21st Century}

As a latecomer to the world of MRAs, the ASEAN region has the opportunity to create a new generation of MRAs based on the most informed notions of how professionals today build, develop, and utilize skills. Although MRAs are essentially 20th-century instruments, they are far from obsolete; in fact, the opposite is true, particularly for a region that is growing and integrating as fast as ASEAN. As Batalova, Shymonyak, and Sugiyarto observe in another report in this series, "ASEAN's regional brain network is expanding and intensifying." High-skilled migrants compose a growing proportion of the region's talent, fueled in part by university students. Furthermore, a significant shift in directional trajectory has taken place: more skilled persons are moving to other ASEAN countries, not just to traditional destinations in North America, Europe, and Oceania. Moreover, these persons are diversifying their movements within ASEAN, as greater numbers arrive in destinations outside Singapore and Brunei Darussalam.

Given the changes in scale, composition, and direction of intraregional flows, all ASEAN Member States are poised to both send and receive substantial numbers of skilled migrants. Only an effective regionwide system of MRAs can ensure that the skills of the dynamic ASEAN labor force are recognized and utilized to the region's utmost advantage. 


\section{Appendixes}

\section{Appendix 1: Methodology}

total of 387 individuals from the ASEAN region and beyond directly contributed to the findings of this report. The Migration Policy Institute (MPI) consulted with officials in all ministries

in the 10 ASEAN Member States directly responsible for Mutual Recognition Arrangement

(MRA) implementation, as well as with private-sector employers, academics, training directors, members of MRA monitoring committees, and current and former ASEAN Secretariat officials.

The research employed a three-pronged approach:

- First, in cooperation with the Asian Development Bank (ADB), MPI convened 12 full days of focus group discussions and meetings between May and September 2015. These forums engaged regional and international experts on mutual recognition and professional mobility, and featured specific presentations on progress and challenges to MRA implementation at national and regional levels. More than 100 MRA stakeholders and experts, including a former Secretary-General of ASEAN, Chair of the ASEAN Business Council, and officials from key ministries in MRA development across ASEAN, attended the convenings. Appendix 2 lists the names and affiliations of all participants in the formal meetings and interviews.

Second, MPI administered a qualitative survey on the development and implementation of MRAs in each Member State The survey examined the specific context of MRA implementation, including evolving bottlenecks to completion. Between August 2015 and February 2016, MPI, working with local researchers in the 10 Member States, received responses from 311 individuals from relevant government ministries, the private sector, professional associations, educational institutions, and the human resources field. Appendix 3 lists the affiliations of all stakeholders who completed the MRA implementation survey (Note: Several respondents chose to omit their names in order to answer more openly).

Third, MPI reviewed key documents and presentations relating to the conclusion and implementation of the ASEAN MRAs on professional services. These included guides and reviews published by ASEAN; handbooks on implementation progress; and studies conducted by the International Labour Organization, Economic Research Institute for ASEAN and East Asia, and ASEAN-Australian Development Cooperation Program Phase II. 


\section{Appendix 2: List of Participants in Formal Meetings and Individual Interviews}

\begin{tabular}{|c|c|}
\hline \multicolumn{2}{|c|}{$\begin{array}{l}\text { Roundtable of High-Level Experts, Bali, Indonesia, 11-12 May 2015, } \\
\text { Convened by Asian Development Bank and Migration Policy Institute }\end{array}$} \\
\hline Abella, Manolo & International Labour Organization MIGRANT Unit \\
\hline Batalova, Jeanne & Migration Policy Institute \\
\hline Bedford, Richard & AUT University, Auckland, New Zealand \\
\hline Chia, Siow Yue & Singapore Institute of International Affairs \\
\hline Desiderio, Maria Vincenza & Migration Policy Institute \\
\hline Doutriaux, Yves & Government of France \\
\hline Fix, Michael & Migration Policy Institute \\
\hline Govindasamy, Jeevakumar & Talent Corporation Malaysia, Government of Malaysia \\
\hline Hasan, Rana & Asian Development Bank \\
\hline Ishikura, Yoko & $\begin{array}{l}\text { Hitotsubashi University; World Economic Forum Global Agenda Council on Education and } \\
\text { Skills }\end{array}$ \\
\hline Majid, Tan Sri Munir & CIMB ASEAN Research Institute and Bank Muamalat Malaysia \\
\hline Mendoza, Dovelyn Rannveig & Migration Policy Institute \\
\hline Narjoko, Dionisius & Economic Research Institute for ASEAN and East Asia (ERIA) \\
\hline Nicolas, Imelda M. & Commission on Filipinos Overseas, Office of the President of the Philippines \\
\hline Papademetriou, Demetrios G. & Migration Policy Institute \\
\hline Santoso, Megawati & ASEAN Task Force on the ASEAN Qualifications Reference Framework \\
\hline Sugiyarto, Guntur & Asian Development Bank \\
\hline Tambo, Ichiro & Japan International Cooperation Agency Research Institute \\
\hline Theroux, Eric & $\begin{array}{l}\text { Ministry of International and Francophone Relations of Québec, Québec Ministry of } \\
\text { International and Francophone Relations }\end{array}$ \\
\hline Pereira, Ana Carla & DG Employment, European Commission \\
\hline Yeoh, Brenda & National University of Singapore \\
\hline
\end{tabular}

\begin{tabular}{|c|c|}
\hline \multicolumn{2}{|c|}{$\begin{array}{l}\text { Focus Group Discussion, Manila, Philippines, 3-4 September 2015, } \\
\text { Convened by Asian Development Bank and Migration Policy Institute }\end{array}$} \\
\hline Abaquin, Carmencita & $\begin{array}{l}\text { Professional Regulatory Board of Nursing, Professional Regulation Commission, Republic of } \\
\text { the Philippines }\end{array}$ \\
\hline Aldaba, Fernando T. & Department of Economics, Ateneo de Manila University, Republic of the Philippines \\
\hline Alipio, Arlene & Department of Tourism, Republic of the Philippines \\
\hline Ang, Alvin & Department of Economics, Ateneo de Manila University, Republic of the Philippines \\
\hline Baromey, Neth & Royal University of Phnom Penh, Cambodia \\
\hline Batalova, Jeanne & Migration Policy Institute \\
\hline Bulaong, Ofelia & Professional Regulation Commission, Republic of the Philippines \\
\hline Chalamwong, Yongyuth & Thailand Development Research Institute \\
\hline Chantavanich, Supang & $\begin{array}{l}\text { Faculty of Political Science and Director, Asian Research Center for Migration, } \\
\text { Chulalongkorn University, Thailand }\end{array}$ \\
\hline Chanthavong, Panya & Ministry of Education and Sports, Lao PDR \\
\hline Dacuycuy, Lawrence & School of Economics, De La Salle University, Republic of the Philippines \\
\hline Dalalom, Phouthone & $\begin{array}{l}\text { Institute of Mass Media, Culture and Tourism, Ministry of Information, Culture } \\
\text { and Tourism, Lao PDR }\end{array}$ \\
\hline Dethoudom, Somphone & Council of Sciences and Technology, Ministry of Public Works \& Transportation, Lao PDR \\
\hline Hasakool, Ruangsang & Office of the Vocation Education Commission, Thailand \\
\hline
\end{tabular}




\begin{tabular}{|c|c|}
\hline \multicolumn{2}{|c|}{$\begin{array}{l}\text { Focus Group Discussion, Manila, Philippines, 3-4 September 2015, } \\
\text { Convened by Asian Development Bank and Migration Policy Institute }\end{array}$} \\
\hline Isaac, Irene & $\begin{array}{l}\text { Policies \& Planning, Technical Education and Skills Development Authority, } \\
\text { Republic of the Philippines }\end{array}$ \\
\hline Korwanich, Narumanas & Dental Council of Thailand \\
\hline Kuouch, Somean & National Employment Agency, Cambodia \\
\hline Leakhena, Sim Chan & National Committee for Tourism Professionals, Ministry of Tourism, Cambodia \\
\hline Lwin, Kyaw & Ministry of Construction, Myanmar \\
\hline Mai, Thanh Tong & Viet Nam Association of Accountants \& Auditors \\
\hline Malindog-Uy, Anna & Asian Development Bank, Consultant \\
\hline Manzala, Teresita & Professional Regulations Commission, Republic of the Philippines \\
\hline Myint, Win & Ministry of Construction, Myanmar \\
\hline Navallo, Katrina & Asian Development Bank, Consultant \\
\hline Nguyen, Ba Ngoc & Institute of Labor Science and Social Affairs, Viet Nam \\
\hline Nguyen, Bich Luu & Viet Nam Nurse Association \\
\hline Nguyen, Lan Huong & Ministry of Health, Viet Nam \\
\hline Nguyen, Thi Thai Lan & University of Labor and Social Affairs, Viet Nam \\
\hline Ochoa-Moreno, Anabelle & Tourism Industry Board, Republic of the Philippines \\
\hline Oum, Sothea & Ngee-Ann Adelaide Education Centre, Cambodia \\
\hline Pham, Ngoc Toan & Institute of Labor Science and Social Affairs, Viet Nam \\
\hline Phan, Thi Dung & Viet Hue University Hospital \\
\hline Phousinghoa, Sengxay & $\begin{array}{l}\text { National Implementation Unit, Department of Planning and Cooperation, Ministry of } \\
\text { Industry and Commerce, Lao PDR }\end{array}$ \\
\hline Phuengkwamchomb, Atinart & Medical Council of Thailand \\
\hline Sriwatanawongsa, Adirek & Dental Association of Thailand \\
\hline Suan, Eric & Asian Development Bank \\
\hline Ta, Bao Luu & Nhatviet Investment Consulting Co., Viet Nam \\
\hline Tran, Viet Hung & Ministry of Health, Viet Nam \\
\hline Tullao Jr., Teresito & De La Salle University Manila, Republic of the Philippines \\
\hline Waikakul, Saranatra & Faculty of Medicine, Sriraj Hospital-Mahidol University, Thailand \\
\hline Win, Zaw & Myanmar Knowledge Management Co. \\
\hline Yorm, Khim & Ministry of Labor and Vocational Training, Cambodia \\
\hline You, Virak & Department of Higher Education, Ministry of Education, Youth, and Sports, Cambodia \\
\hline
\end{tabular}

Focus Group Discussion, Bali, Indonesia, 26-27 September 2015,

Convened by Asian Development Bank and Migration Policy Institute

Ananta, Aris

Ariyanto, Tetty DS

Aung, Aye Aye

Batalova, Jeanne

Chan, Chong Kong

Desiderio, Maria Vincenza

Djajadihardja, Yusuf Surachman

Fahmi, Zita Mohd

Fix, Michael

Hasan, Chotib
University of Indonesia

Inspire Travel and Tourism Learning Centre

Asia Mega Link Company Limited

Migration Policy Institute

Human Capital, PriceWaterhouse Coopers

Migration Policy Institute

Geospatial Information Infrastructure, Badan Informasi Geospasial

Malaysian Qualifications Agency, ASEAN Quality Assurance Network Executive Board

Migration Policy Institute

University of Indonesia 


\begin{tabular}{|c|c|}
\hline \multicolumn{2}{|c|}{$\begin{array}{l}\text { Focus Group Discussion, Bali, Indonesia, 26-27 September 2015, } \\
\text { Convened by Asian Development Bank and Migration Policy Institute }\end{array}$} \\
\hline Hasan, Isnarti & Ministry of Labor, Indonesia \\
\hline Htoon, Ye Swe & Border Areas Development Association, Myanmar \\
\hline Lwin, Kyi & Myanmar Engineering Society \\
\hline Marhzan, Nurmazilah Dato & Malaysian Institute of Accountants \\
\hline Mendoza, Dovelyn Rannveig & Migration Policy Institute \\
\hline Omar, Amir & Economic Planning Unit, Malaysia \\
\hline Paryono & SEAMO VOCTECH Brunei Regional Centre \\
\hline Salleh, Adinin Md & Brunei Darussalam National Accreditation Council, Ministry of Education \\
\hline Salant, Brian & Migration Policy Institute \\
\hline Santoso, Megawati & ASEAN Task Force on the ASEAN Qualifications Reference Framework \\
\hline Shahima, Wan Yon & Human Resources Development Fund, Ministry of Human Resources, Malaysia \\
\hline Suprajaka & Indonesia Geospatial Information Board \\
\hline Sumaryono & Human Resources and Industry for Special Information, Indonesia \\
\hline Sugiyarto, Guntur & Asian Development Bank \\
\hline Thangavelu, Shandre Mugan & University of Adelaide, Centre for International Economic Studies \\
\hline Tjiptoherijanto, Prijono & University of Indonesia \\
\hline Zakaria, Aminuddin & Malaysia Airlines Berhad \\
\hline
\end{tabular}

\section{Appendix 3: Affiliations of Stakeholders Who Completed MRA Implementation Survey}

\begin{tabular}{|l|l|}
\hline \multicolumn{2}{|c|}{ Brunei Darussalam } \\
\hline Brunei Darussalam National Accreditation Council & KPMG Brunei \\
\hline $\begin{array}{l}\text { Brunei Institute of Certified Public Accountants - FTMS } \\
\text { Accountancy Academy }\end{array}$ & Lee and Raman, CPA \\
\hline Brunei Medical Board & Ministry of Health \\
\hline Brunei Shell Petroleum Co. & Ministry of Primary Resources \& Tourism \\
\hline Deloitte & Nursing Board for Brunei \\
\hline Institut Teknologi Brunei & Nursing Services Unit, Suri Seri Begawan Hospital, Kuala Belait \\
\hline Juntera OMC (OMC Engineering) & $\begin{array}{l}\text { Pengiran Anak Puteri Rashidah Sa'datul Bolkiah Institute of } \\
\text { Health Sciences, UBD }\end{array}$ \\
\hline Juruukur Bahan Dan Pengurusan Utamacon & VSL Systems (B) \\
\hline
\end{tabular}

\begin{tabular}{|l|l|}
\hline \multicolumn{2}{|c|}{ Cambodia } \\
\hline Aplus Consulting Co. & KPMG Cambodia \\
\hline Board of Engineers & Moha Engineering \& Consulting Co. \\
\hline Cambodia Society of Architects & National Accounting Council \\
\hline Cambodian Mekong University & $\begin{array}{l}\text { National Committee for Tourism Professionals, Ministry of } \\
\text { Tourism }\end{array}$ \\
\hline Cambodian University for Specialties & Norton University \\
\hline Central Hospital, Phnom Penh & PSE Institute \\
\hline Chenla University & Roomchang Dental Hospital \\
\hline Dara Airport Hotel & Sakal Dental Clinic \\
\hline HRDP \& Associates & Secret Villa \\
\hline
\end{tabular}




\section{Cambodia}

\begin{tabular}{|l|l|}
\hline HR Cambodia & University of Puthisastra, Department of Dentistry \\
\hline International SOS & University of Puthisastra, Department of Midwifery \\
\hline Kampuchea Dental Clinic & Urban Architect of CTS Group \\
\hline $\begin{array}{l}\text { Kampuchea Institute of Certified Public Accountants and } \\
\text { Auditors }\end{array}$ & \\
\hline
\end{tabular}

\section{Indonesia}

\begin{tabular}{|c|c|}
\hline University of Bina Nusantara & Lembaga Profesional Pariwisata Indonesia (LEPPI) \\
\hline $\begin{array}{l}\text { BNP2TKI (National Board of Placement and Protection of } \\
\text { Indonesian Migrant Worker) }\end{array}$ & Ministry of Tourism \\
\hline BNSP (Indonesian Professional Certification Authority) & $\begin{array}{l}\text { National Professional Certification Board, Ministry of Manpower } \\
\text { (BNSP) }\end{array}$ \\
\hline Committee on Human Resources in Health & Obat24.com \\
\hline Faculty of Agriculture, Bogor Agricultural University & $\begin{array}{l}\text { Persuatan Insinyur Indonesia (Indonesia Association of } \\
\text { Engineers) - PII }\end{array}$ \\
\hline Faculty of Dentistry, University of Indonesia & $\begin{array}{l}\text { Program Pendidikan Vokasi (Vocational Training Programme), } \\
\text { Universitas Indonesia }\end{array}$ \\
\hline Faculty of Economics, University of Indonesia & PT Hagalink (HAGALINK) \\
\hline Badan Geospatial Information Board & $\begin{array}{l}\text { School of Business and Management, Institut Teknologi } \\
\text { Bandung }\end{array}$ \\
\hline Ikatan Akuntan Indonesia (Indonesian Accountant Association) & The ASEAN Secretariat \\
\hline Indonesian Institute of Science (LIPI) & $\begin{array}{l}\text { Master of Accounting and Accounting Profession Program, } \\
\text { University of Indonesia }\end{array}$ \\
\hline Inspire Travel and Tourism Learning Centre & Vocational Programme, University of Indonesia \\
\hline Institution of Indonesia Chartered Accountants & \\
\hline
\end{tabular}

\begin{tabular}{|c|c|}
\hline \multicolumn{2}{|c|}{ Lao PDR } \\
\hline Burapha Agro-Forestry Co. & Faculty of Nursing Services, University of Health Sciences \\
\hline Children's Hospital & Friendship Hospital \\
\hline $\begin{array}{l}\text { Council of Sciences and Technology, Ministry of Public Works } \\
\text { and Transport }\end{array}$ & Geographic Department, Ministry of Home Affairs \\
\hline Dental Clinic Department, Ministry of Health & Health Care Department, Ministry of Health \\
\hline Dental Clinic, University of Health Sciences & Institute of Mass Media, Culture, and Tourism \\
\hline Dental Department, Mahosot Hospital & Lao Development Bank \\
\hline Dental Faculty, University of Health Sciences & Lao Hotel and Restaurant Association \\
\hline $\begin{array}{l}\text { Department of Electrical Engineering, National University of } \\
\text { Laos }\end{array}$ & Lao Institute of Certified Public Accountants \\
\hline Department of Geology and Minerals & Lao National Chamber of Commerce and Industry \\
\hline Department of Land Administration & Lao Toyota Service Co. \\
\hline Department of Mines, Ministry of Energy and Mines & Ministry of Finance, Accounting Department \\
\hline Department of Nursing Service, Ministry of Health & MMG LXML Sepon \\
\hline $\begin{array}{l}\text { Department of Roads, Ministry of Public Works and Transport } \\
\text { (MPWT) }\end{array}$ & National Audit Organization \\
\hline $\begin{array}{l}\text { Educational Standards and Quality Assurance Center, Ministry } \\
\text { of Education and Sports }\end{array}$ & Nursing Service Faculty, University of Health Sciences \\
\hline Exo Travel Laos & National University of Laos, Faculty of Engineering, Dean Office \\
\hline Fa Jewelry & Pakpasak Technical College \\
\hline
\end{tabular}


Lao PDR

Faculty of Architecture, Department of Architecture, National University of Laos

Faculty of Architecture, Department of Environment and Urban Planning, National University of Laos

Faculty of Dentistry, University of Health Sciences

Faculty of Engineering, Department of Electrical Engineering, National University of Laos

Faculty of Hotel and Tourism, National University of Laos
Polytechnics Institute

Survey and Mapping Center, Ministry of Home Affairs

Tourism Development Department, Ministry of Information, Cultures, and Tourism

Vientiane Plaza Hotel

Wonderful Garment

\begin{tabular}{|l|l|}
\hline \multicolumn{2}{|c|}{ Malaysia } \\
\hline Berjaya University College of Hospitality & Malaysian Dental Association \\
\hline Department of Skills Development & Malaysian Institute of Accountants (PRA/NAB) \\
\hline International Islamic University of Malaysia & Malaysian Medical Association \\
\hline International Medical University & Medical Practice Division, Ministry of Health \\
\hline JobStreet.com & Melorita Healthcare \\
\hline JUBM & Ministry of Tourism and Culture \\
\hline Land Surveyors Board of Malaysia & Prince Court Medical Centre \\
\hline Lincoln University College & Robert Walters of Malaysia \\
\hline Malaysian Accountancy Research and Education Foundation & Westports Malaysia \\
\hline Malaysian Accounting Standards Board & \\
\hline
\end{tabular}

\begin{tabular}{|l|l|}
\hline Asia Mega Link Company Limited & Ministry of Social Welfare \\
\hline Asia Royal Hospital & Myanmar Academy of Medical Science \\
\hline Association of Myanmar Architects & Myanmar Accountancy Council \\
\hline City Development Council & Myanmar Architect Council \\
\hline Department of Civil Aviation, Ministry of Transport & Myanmar Business Executives Association \\
\hline Defense Services Medical Academy & Myanmar Dental Council \\
\hline Dental Association & Myanmar Engineering Council \\
\hline Engineering Council & Myanmar Engineering Society \\
\hline Insein General Hospital & Myanmar Institute of Certified Public Accountants \\
\hline Institute of Dental Medicine & Myanmar Medical Association \\
\hline MAT Audit and Professional Services & Myanmar Medical Council \\
\hline MC Audit & Myanmar Nurses and Midwifery Association \\
\hline Military Nursing Paramedical and Pharmacy Institute & Myanmar Nursing and Midwifery Council \\
\hline Ministry of Construction & National Skill Standards Authority \\
\hline Ministry of Education, Higher Education & Nursing University \\
\hline Ministry of Education & People's Health Foundation \\
\hline Ministry of Health & Tourism Promotion Department \\
\hline Ministry of Health, Department of Medical Services & Tourism Training School \\
\hline Ministry of Industry & Win Htut Aung and Associates \\
\hline Ministry of Labor, Employment, and Security & \\
\hline
\end{tabular}




\begin{tabular}{|c|c|}
\hline \multicolumn{2}{|c|}{ Philippines } \\
\hline Asian Institute of Management & Professional Regulatory Board of Nursing \\
\hline Ateneo de Manila University School of Medicine & School of Economics, De La Salle University \\
\hline Board of Accountancy, Professional Regulation Commission & Technical Education and Skills Development Authority (TESDA) \\
\hline Department of Tourism & The Medical City \\
\hline $\begin{array}{l}\text { Health Alternatives for Total Human Development } \\
\text { (HEALTHDEV) Institute }\end{array}$ & Tourism Industry Board Foundation \\
\hline $\begin{array}{l}\text { Professional Regulation Commission, Board, Mechanical } \\
\text { Engineering }\end{array}$ & University of Santo Tomas \\
\hline $\begin{array}{l}\text { Professional Regulation Commission, Regulatory Board of } \\
\text { Architecture }\end{array}$ & University of the Philippines Asian Institute of Tourism \\
\hline $\begin{array}{l}\text { Professional Regulation Commission, Board of Geodetic } \\
\text { Engineering }\end{array}$ & University of the Philippines College of Dentistry \\
\hline Professional Regulation Commission, Board of Dentistry & University of the Philippines College of Nursing \\
\hline
\end{tabular}

\begin{tabular}{|c|c|}
\hline \multicolumn{2}{|c|}{ Thailand } \\
\hline 17th Somdejprasangkaraj Hospital & Medical Association of Thailand \\
\hline Architect Council of Thailand & Medical Council of Thailand \\
\hline Chulalongkorn Memorial Hospital & $\begin{array}{l}\text { Office of the Permanent Secretary, Ministry of Tourism and } \\
\text { Sports }\end{array}$ \\
\hline Council of Engineers & $\begin{array}{l}\text { Office of the Vocational Education Commission, Ministry of } \\
\text { Education }\end{array}$ \\
\hline Dental Association of Thailand & Pan House Travel / Association of Thai Travel Agents (ATTA) \\
\hline Dental Council of Thailand & Siriraj Hospital \\
\hline Department of Skill Development & Somsilp Co. \\
\hline Director of Business Development, Ministry of Commerce & SSC Rental \& Engineering Co. \\
\hline Dusit International & Thai Red Cross College of Nursing \\
\hline Faculty of Accountancy, Chulalongkorn University & Thailand Development Research Institute (TDRI) \\
\hline Faculty of Dentistry, Chulalongkorn University & Thailand Medical Council \\
\hline Faculty of Engineering, Chulalongkorn University & Thailand Nurses Association of Thailand \\
\hline $\begin{array}{l}\text { Faculty of Humanities and Social Sciences, Suansunandha } \\
\text { Rajabhat University }\end{array}$ & Thailand Nursing and Midwifery Council \\
\hline Faculty of Medicine, Chulalongkorn University & Thammathorn Accountancy \\
\hline Faculty of Medicine, Siriraj Hospital, Mahidol University & $\begin{array}{l}\text { Tourism Professional Training Institute, Office of the Permanent } \\
\text { Secretary, Ministry of Tourism and Sports }\end{array}$ \\
\hline Federation of Accounting Professions & Tripple P Accounting \\
\hline King Chulalongkorn Memorial Hospital & V.S.P. Construction Co. \\
\hline Kopfun Co. & \\
\hline
\end{tabular}




\begin{tabular}{|c|c|}
\hline \multicolumn{2}{|c|}{ Viet Nam } \\
\hline Administration for Medical service, Ministry of Health & Ministry of Construction \\
\hline Central Public Hospital of Odonto and Stomatology & Ministry of Health \\
\hline $\begin{array}{l}\text { Department of International Cooperations, Ministry of } \\
\text { Construction }\end{array}$ & $\begin{array}{l}\text { Ministry of Health, Department of Healthcare Examination } \\
\text { Management, Socialist Republic of Viet Nam }\end{array}$ \\
\hline Department of International Relations, Ministry of Construction & Ministry of Labor, Invalids, and Social Affairs (MOLISA) \\
\hline $\begin{array}{l}\text { Department of Managing Construction Activities, Ministry of } \\
\text { Construction }\end{array}$ & Nhat Viet Investment Consulting Company Limited \\
\hline Department of National Remote Sensing & Sapio Tourism \\
\hline Department of Surveying and Mapping & Southern Transportation Consultancy and Designing Company \\
\hline Dong Hung Accounting Services Co. & VietDuc Hospital \\
\hline $\begin{array}{l}\text { European Union-funded Environmentally and Socially } \\
\text { Responsible Tourism Capacity Development Programme } \\
\text { (ESRT) }\end{array}$ & Viet Nam Association of Accountants and Auditors (VAA) \\
\hline Faculty of Accounting, University of Labor and Social Affairs & Viet Nam Consultancy Construction Company \\
\hline GITES JSC & Viet Nam Institute of Geodesy and Cartography \\
\hline Ha Noi Tourism College & Viet Nam National Administration of Tourism \\
\hline Ha Noi Medical University & Viet Nam Nursing Association \\
\hline $\begin{array}{l}\text { Institute of Labor Science and Social Affairs (ILSSA)- Ministry } \\
\text { of Labor, Invalids, and Social Affairs (MOLISA) }\end{array}$ & Viet Nam Tourism Certification Board \\
\hline JSC Developed Architecture and Construction KINESIS & Viet Nam Young Physician Association \\
\hline Khanh Hoa Mental Health Hospital & Viet Nam, Odonto, Stomatology Association (VOSA) \\
\hline KTV Advisory and Auditing & \\
\hline
\end{tabular}




\section{References}

Anwar, Arif and David Richards. 2013. Is the USA Set to Dominate Accreditation of Engineering Education and Professional Qualifications? Civil Engineering 166 (CE1): 42-48.

Architects Accreditation Council of Australia (AACA). 2013. APEC Architect Supplementary Assessment Process. Canberra: AACA. www.aaca.org.au/wp-content/uploads/2013/10/October-2013-Domainspecific-assessment-process1.pdf.

Asia-Pacific Economic Cooperation (APEC). 2014. APEC Architect Operations Manual. Vancouver: APEC. www.apecarchitects.org/images/pdf/repairs/operations-manual-2014.pdf.

——. N.d. APEC Architect Framework. Accessed 6 July 2016. http://apecarchitects.org/index. php?option=com_content\&view=article\&id=62\&ltemid $=74$.

—_ N.d. Bilaterals. Accessed 26 May 2016. www.apecarchitects.org/index.php?option=com_content\&vie $\mathrm{w}=$ article\&id $=84 \&$ ltemid $=102$.

- - N.d. Registration as an APEC Architect. Accessed 6 July 2016. http://apecarchitects.org/index. php?option=com_content\&view=article\&id=63\&ltemid $=76$.

_- N.d. What is Asia-Pacific Economic Cooperation? Accessed 6 July 2016. www.apec.org/About-Us/ About-APEC.aspx.

Australian Government, Department of Foreign Affairs and Trade. 2016. Australia-New Zealand Closer Economic Relations Trade Agreement. Updated February 2016. http://dfat.gov.au/trade/agreements/ anzcerta/pages/australia-new-zealand-closer-economic-relations-trade-agreement.aspx.

Australian Government, Department of Immigration and Border Protection. N.d. Skills Assessment and Assessing Authorities. Accessed 3 June 2016. www.border.gov.au/Trav/Work/Work/Skills-assessmentand-assessing-authorities.

Australian Government, Productivity Commission. 2015. Mutual Recognition Schemes: Productivity Commission Research Report. Canberra: Australian Government Productivity Commission. www.pc.gov.au/inquiries/ completed/mutual-recognition-schemes/report/mutual-recognition-schemes.pdf.

Barbados Accreditation Council. N.d. Overview. Accessed 21 June 2016. https://bac.gov.bb/Services/ SkillsCertificate/. 
Basri, Hassan, A. B. Che Man, Wan Hamidon Wan Badaruzzaman, and Mohd Jailani Mohd Nor. 2014. Malaysia and the Washington Accord: What It Takes for Full Membership. International Journal of Engineering and Technology 1 (1): 64-73.

Batalova, Jeanne, Andriy Shymonyak, and Guntur Sugiyarto. 2016. Firing Up Regional Brain Networks: The Promise of Brain Circulation in the ASEAN Economic Community. Manila, Philippines: Asian Development Bank.

Caribbean Community (CARICOM). 1997. Caribbean Community (Free Movement of Skilled Persons) Act, 15 July 1997. http://moj.gov.jm/sites/default/files/laws/CCFMSP\%20Act.pdf.

__. N.d. CARICOM Single Market and Economy (CSME): Overview. Accessed 25 August 2016. http:// caricom.org/work-areas/overview/caricom-single-marke-and-economy.

CARICOM, Single Market and Economy (CSME) Unit. 2014. CSME_Freedom of Movement. 2 April 2014. www.csmeonline.org/news/video/csme-freedom-of-movement.

Collège des Médecins du Québec, Ministère de la Santé de la République Française, Conseil National de l'Ordre des Médecins de France. 2009. Arrangement en Vue de la Reconnaissance Mutuelle des Qualifications Professionnelle des Médecins, 27 November 2009. www.immigration-quebec.gouv. qc.ca/publications/fr/arm/ARM-medecins.pdf.

Commonwealth of Australia. 2014. A Users' Guide to the Mutual Recognition Agreement (MRA) and the TransTasman Mutual Recognition Arrangement (TTMRA). Canberra: Commonwealth of Australia. Revised 2014. www.mbie.govt.nz/info-services/business/trade-tariffs/documents-image-library/Users\%20 guide\%20to\%20the\%20Trans-Tasman\%20Mutual\%20Recognition\%20Arrangement\%20-PDF\%20 516\%20KB.pdf.

Council of the European Communities. 1975. Council Directive of 16 June 1975 concerning the mutual recognition of diplomas, certificates and other evidence of formal qualifications in medicine, including measures to facilitate the effective exercise of the right of establishment and freedom to provide services (75/362/EEC). Official Journal L167, 30 June 1975. http://eur-lex.europa.eu/legal-content/EN/ TXT/PDF/? uri=CELEX:31975L0362\&from=EN.

- - 1975. Council Directive 75/363/EEC of 16 June 1975 concerning the coordination of provisions laid down by law, regulation or administrative action in respect of activities of doctors. Official Journal L 167, 30 June 1975, 14-16. http://eur-lex.europa.eu/legal-content/EN/TXT/?uri=CELEX:31975L0363.

Crisp, Arthur H. 1990. Medical Training in the European Community. Postgraduate Medical Journal 66 (778): 627-38.

Dixon, Matthew. 2013. Skills, Professional Regulation, and International Mobility in the Engineering Workforce. Washington, DC: Migration Policy Institute. www.migrationpolicy.org/research/skills-professionalregulation-and-international-mobility-engineering-workforce.

Doyle, Kate. 2016. Author interview with Kate Doyle, CEO of the Architects Accreditation Council of Australia (AACA), 27 May 2016. 
Engineers Australia. 2016. Migration Skills Assessment Booklet. January 2016. www.engineersaustralia.org. au/sites/default/files/shado/About\%20Us/Migration\%20Skills\%20Assessment/msa_booklet-finalmarch-2016.pdf.

Engineers Canada. N.d. Licensing in Canada. Accessed 10 May 2016. http://newcomers.engineerscanada.ca/ licensing-canada.

_- _. N.d. Academic Information Tool. Accessed 10 May 2016. http://newcomers.engineerscanada.ca/ academic-information-tool.

European Commission. 2001. Guide for Users of the General System for the Recognition of Professional Qualifications. MARKT/D/8327/2001-EN. Brussels: European Commission. http://ec.europa.eu/ internal_market/qualifications/docs/guide/guide_en.pdf.

- 2010. Commission Staff Working Document on the Transposition and Implementation of the Professional Qualifications Directive (Directive 2005/36/EC). Brussels: European Commission. http://ec.europa.eu/ internal_market/qualifications/docs/evaluation/staff-working-doc_en.pdf.

2011. Evaluation of the Professional Qualifications Directive (Directive 2005/36/EC). Brussels: European Commission. http://ec.europa.eu/internal_market/qualifications/docs/news/20110706-evaluationdirective-200536ec_en.pdf.

___. N.d. Statistics. The EU Single Market Regulated Professions Database. Accessed 9 May 2016. http:// ec.europa.eu/growth/tools-databases/regprof/index.cfm.

___. N.d. From 6 to 28 Members. Accessed 23 June 2016. http://ec.europa.eu/enlargement/policy/from-6to-28-members/index_en.htm.

European Union. 1975. Council Directive 75/362/EEC of 16 June 1975 concerning the mutual recognition of diplomas, certificates and other evidence of formal qualifications in medicine, including measures to facilitate the effective exercise of the right of establishment and freedom to provide services. Official Journal L 167, 30 June 1975, 1-13. http://eur-lex.europa.eu/legal-content/EN/ TXT/?uri=CELEX\%3A31975L0362.

2005. Directive 2005/36/EC of the European Parliament and of the Council of 7 September 2005 on the recognition of professional qualifications. Official Journal L 255/22, 30 September 2005. http://eurlex.europa.eu/legal-content/EN/TXT/?uri=CELEX:02005L0036-20110324.

Girvan, Norman. 2006. Towards a Single Economy and a Single Development Vision. Greater Georgetown, Guyana: CARICOM Secretariat and the Special Task Force on the Single Economy. www.caribank. org/uploads/publications-reports/research/conference-papers/regional-conference-on-csme/ GirvanTowardsSingleEconomy[1].pdf.

Gouvernement du Quebéc. 2010. Arrangement en vue de la Reconnaissance Mutuelle des Qualifications Professionnelles entre L'Ordre des Infirmières et Infirmiers du Québec et la Ministre de la Santé et des Sports et L'Ordre National des Infirmiers de France. Quebéc: Gouvernement du Quebéc. www.immigrationquebec.gouv.qc.ca/publications/fr/arm/ARM-infirmieres.pdf. 
2014. Avenant à L'Arrangement en vue de la Reconnaissance Mutuelle des Qualifications Professionnelles des Infirmières et Infirmiers Signéle 13 Août 2010. Quebéc: Gouvernement du Quebéc. www.immigrationquebec.gouv.qc.ca/publications/fr/arm/Avenant-infirmieres.pdf.

Government of the Republic of Trinidad and Tobago, Ministry of Foreign and CARICOM Affairs. N.d. CSME. Accessed 21 June 2016. https://foreign.gov.tt/services/csme/.

Hanrahan, Hu. 2008. The Washington Accord: History, Development, Status and Trajectory. Paper presented at the 7th Annual ASEE Global Colloquium on Engineering Education, Cape Town, 19-23 October 2008. www.asee.org/documents/conferences/international/2008/Hanrahan-Accreditation-TrackWA-Paper.doc.

2011. The Washington Accord Past, Present, Future. Presentation at IEET Accreditation Training, Taipei,China, September 2011. www.ieagreements.org/Washington-Accord/Washington-AccordOverview.pdf.

International Engineering Alliance (IEA). 2014. 25 Years - Washington Accords (1989-2014): Celebrating International Engineering Education Standards and Recognition. Wellington, New Zealand: IEA. www. ieagreements.org/25_years/25YearsWashingtonAccord-A5booklet-FINAL.pdf.

_- 2014. Educational Accords: Washington Accord, 1989; Sydney Accord, 2001; Dublin Accord, 2002. Updated 13 June 2014. www.ieagreements.org/Rules_and_Procedures.pdf?7432.

Johnson, Nathan. 2015. First Australian Architect Registers in Canada under New Mutual Recognition Arrangement. Architecture \& Design, 20 July 2015. www.architectureanddesign.com.au/news/firstaustralian-architect-registers-in-canada-und.

Kaieteur News. 2014. 14,000 CARICOM Skills Certificates Issued-Says CARICOM Secretary General. Kaieteur News, 11 November 2014. www.kaieteurnewsonline.com/2014/11/11/14000-caricom-skillscertificates-issued-says-caricom-secretary-general/.

Keighley, Thomas. 2009. European Union Standards for Nursing and Midwifery: Information for Accession Countries, 2nd ed. Copenhagen: World Health Organization.

Kendall, Patrick. 2007. Globalisation, Trade Liberalisation and the CARICOM Single Market and Economy. Paper presented at the 39th Annual Monetary Studies Conference, Belize City, Belize, 6-9 November 2007. http://new.ccmfuwi.org/files/publications/conference/947.pdf.

Mahabir, Raghunath. 2007. Migration of Skilled Personnel in the CSME: A Case Study of Trinidad and Tobago. Social and Economic Studies 56 (4): 207-39.

Ministère de L'Immigration et Communautés Culturelles of Québec. 2011. Liste des functions du domaine des assurances, des valeurs mobilières et des instruments financiers pour lesquels un arrangement de reconnaissance mutuelle a été signé. Québec: Ministère de L'Immigration et Communautés Culturelles. www.immigration-quebec.gouv.qc.ca/publications/fr/arm/Liste-fonctions-ARM.pdf. 
2013. Liste des métiers pour lesquels un arrangement de reconnaissance mutuelle a été signé. Québec: Ministère de L'Immigration et Communautés Culturelles. www.immigration-quebec.gouv. qc.ca/publications/fr/arm/Liste-metiers-ARM.pdf.

2014. Liste des professions pour lesquelles un arrangement de reconnaissance mutuelle a été signé. Québec: Ministère de L'Immigration et Communautés Culturelles. www.immigration-quebec.gouv.qc.ca/ publications/fr/arm/Liste-professions-ARM.pdf.

Ministère des Relations internationales et de la Francophonie (MRIF). N.d. France-Québec Agreement on the Mutual Recognition of Professional Qualifications: Common Procedure for the Recognition of Professional Qualifications (Diagram). Accessed 21 June 2016. www.mrif.gouv.qc.ca/Content/ documents/en/procedure_commune_entente_qualif_prof_FrQc_en.pdf.

National Council of Architectural Registration Boards (NCARB). N.d. NCARB's Advisor to the CEO Awarded International Medal. Accessed 25 August 2016. www.ncarb.org/About-NCARB/Council-Organization/ Management-Team/NuttAward.aspx\#sthash.zu8n7zco.dpuf.

NCARB and Canadian Architectural Licensing Authorities (CALA). 2013. Mutual Recognition Agreement between the National Council of Architectural Registration Boards and the Canadian Architectural Licensing Authorities (CALA). San Diego, California, 17 June 2013. www.ncarb.org/Publications/ / media/Files/PDF/Special-Paper/2013ncarb-cala_mra.pdf.

National Training Agency. N.d. Overview -What Is the CVQ? Accessed 25 August 2013. http://ntatvetcentre. org/cvq_overview.aspx.

Nicholas, Sallie. 2004. The Challenges of Free Movement of Health Professionals. In Health Policy and European Union Enlargement, eds. Martin McKee, Laura MacLehose, and Ellen Nolte. New York and Maidenhead, UK: Open University Press.

Nielson, Julia. 2004. Chapter 10-Trade Agreements and Recognition. In Quality and Recognition in Higher Education-The Cross-Border Challenge. Paris: OECD Publishing. www.oecd.org/edu/skills-beyondschool/33729996.pdf.

Nutt, Stephen. 2016. Author interviews with Stephen Nutt, Chief Advisor to the CEO of the National Council of Architectural Registration Boards (NCARB). 12 and 30 May 2016.

Papademetriou, Demetrios G., Dovelyn Rannveig Mendoza, Brian Salant, and Guntur Sugiyarto. 2016. Achieving Skill Mobility in the ASEAN Economic Community: Challenges, Opportunities, and Policy Implications. Manila: Asian Development Bank. www.migrationpolicy.org/research/achieving-skillmobility-asean-economic-community-challenges-opportunities-and-policy.

Plimmer, Frances. 2004. Mutual Recognition of Professional Qualifications: The European Union System. Background paper for the 3rd FIG Regional Conference, Jakarta, Indonesia, 3-7 October 2004.

Premier Ministre du Québec et Le Président de la République Française. 2008. Entente entre le Québec et La France En Matière de Reconnaissance Mutuelle des Qualifications Professionelles. Québec, Canada, 17 October 2008. www.mrif.gouv.qc.ca/Content/documents/fr/2008-12.pdf. 
Relations internationales et Francophonie Québec. N.d. Detailed Information about the Agreement. Accessed 21 June 2016. www.mrif.gouv.qc.ca/en/ententes-et-engagements/ententes-internationales/ reconnaissance-qualifications/entente-en-details.

Riemsdijk, Micheline van. 2013. Obstacles to the Free Movement of Professionals: Mutual Recognition of Professional Qualifications in the European Union. European Journal of Migration and Law 15 (1): 47-68.

Santé et Services sociaux Québec. N.d. Arrangement de reconnaissance mutuelle (ARM) des compétences Québec-France pour les médecins. Accessed 20 April 2016. www.msss.gouv.qc.ca/sujets/organisation/ medecine/rsq/index.php?arm-quebec-france.

Schröder, Sonja. 2010. Regional Approaches in Managing Migration: A Comparative View. Paper presented at "Migration: A World in Motion, A Multinational Conference on Migration and Migration Policy," Maastricht, the Netherlands, 18-20 February 2010. www.umdcipe.org/conferences/Maastricht/conf_ papers/Papers/Regional_Approaches_in_Managing_Migration.pdf.

Trinidad and Tobago Ministry of National Security, Immigration Division. N.d. CSME Caricom Single Market and Economy. Accessed 21 June 2016. www.immigration.gov.tt/Services/CSME.aspx.

Wilkins, Roger. 1995. Mutual Recognition: The First Eight Months. In The Australian Mutual Recognition Scheme: A New Approach to an Old Problem, eds. Tony Thomas and Cheryl Saunders. Melbourne: Centre for Comparative Constitutional Studies, University of Melbourne.

World Trade Organization (WTO). N.d. Council for Trade in Services, Technical and Administrative Information, Notifications, Article 7.4. Database used for Figures 1, 2, and 3. Accessed 1 September 2016. https://docs.wto.org/dol2fe/Pages/FE_Browse/FE_B_009.aspx?TopLevel=8660\#/.

Zarrilli, Simonetta. 2005. Moving Professionals beyond National Borders: Mutual Recognition Agreements and the GATS United Nations Conference on Trade and Development. Working paper UNCTAD/ DITC/TNCD/2005/2, United Nations Conference on Trade and Development, Geneva, February 2005. http://unctad.org/en/Docs/ditctncd20052_en.pdf. 


\section{Reinventing Mutual Recognition Arrangements: \\ Lessons from International Experiences and Insights for the ASEAN Region}

Governments and nonstate actors around the world have signed mutual recognition arrangements (MRAs), but while most of them share the goals of streamlining the recognition of foreign workers' qualifications and boosting labor mobility, the MRAs vary considerably. Implementation challenges faced in the Americas, Asia and the Pacific, and Europe offer lessons for Asian policymakers seeking to operationalize the MRAs of the Association of Southeast Asian Nations (ASEAN). This report is the latest in a project by the Asian Development Bank and the Migration Policy Institute to improve understanding of the barriers to the free movement of professionals within ASEAN and to support the development of strategies to overcome these hurdles. The report draws on insights of nearly 400 ASEAN and member state officials, private sector employers, training directors, and others who participated in focus group discussions, meetings, and surveys.

\section{About the Asian Development Bank}

ADB's vision is an Asia and Pacific region free of poverty. Its mission is to help its developing member countries reduce poverty and improve the quality of life of their people. Despite the region's many successes, it remains home to a large share of the world's poor. ADB is committed to reducing poverty through inclusive economic growth, environmentally sustainable growth, and regional integration.

Based in Manila, ADB is owned by 67 members, including 48 from the region. Its main instruments for helping its developing member countries are policy dialogue, loans, equity investments, guarantees, grants, and technical assistance.

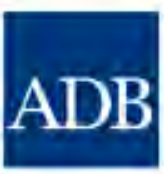

\section{Japan Fund for Poverty Reduction}
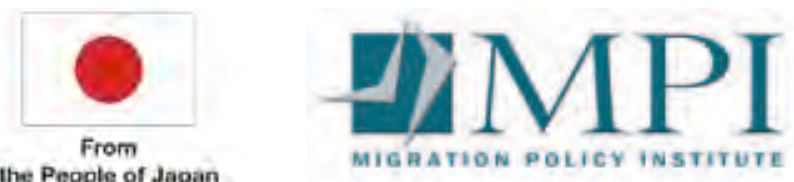